\title{
An Exploratory Study of the Formation and Impact of Electronic Service Failures
}

Tan, Chee-Wee; Benbasat, Izak; Cenfetelli, Ronald

\author{
Document Version \\ Final published version \\ Published in: \\ MIS Quarterly \\ DOI: \\ 10.25300/MISQ/2016/40.1.01 \\ Publication date: \\ 2016 \\ License \\ Unspecified
}

Citation for published version (APA):

Tan, C-W., Benbasat, I., \& Cenfetelli, R. (2016). An Exploratory Study of the Formation and Impact of Electronic Service Failures. MIS Quarterly, 40(1), 1-29. https://doi.org/10.25300/MISQ/2016/40.1.01

Link to publication in CBS Research Portal

\section{General rights}

Copyright and moral rights for the publications made accessible in the public portal are retained by the authors and/or other copyright owners and it is a condition of accessing publications that users recognise and abide by the legal requirements associated with these rights.

\section{Take down policy}

If you believe that this document breaches copyright please contact us (research.lib@cbs.dk) providing details, and we will remove access to the work immediately and investigate your claim.

Download date: 26. Apr. 2023
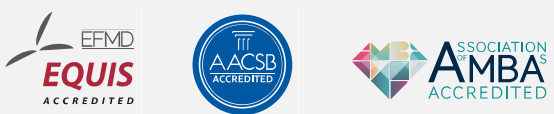


\section{An Exploratory Study of the Formation and Impact of Electronic Service Failures}

\section{Chee-Wee Tan, Izak Benbasat and Ronald Cenfetelli}

Journal article (Publishers version)

This article was originally published in MIS Quarterly, Vol. 40, №. 1, pp. 1-29.

Uploaded to Research@CBS: February २०16 


\title{
AN EXPLORATORY STUDY OF THE FORMATION AND IMPACT OF ELECTRONIC SERVICE FAILURES ${ }^{1}$
}

\author{
Chee-Wee Tan \\ Department of IT Management, Copenhagen Business School, Howitzvej 60, \\ Fredericksberg 2000 DENMARK \{cta.itm@cbs.dk\} \\ Izak Benbasat and Ronald T. Cenfetelli \\ Sauder School of Business, University of British Columbia, 2053 Main Mall, \\ Vancouver, BC V6T 1 Z2 CANADA \{izak.benbasat@sauder.ubc.ca\} \{cenfetell@sauder.ubc.ca\}
}

\begin{abstract}
E-commerce service failures have been the bane of e-commerce, compelling customers to either abandon transactions entirely or switch to traditional brick-and-mortar establishments. Yet, there is a paucity of studies that investigates how such failures manifest on e-commerce websites and their impact on consumers. This paper, therefore, synthesizes extant literature on e-service and system success to arrive at a novel classification system that delineates e-commerce service failures into information, functional, and system categories, each with its own set of constituent dimensions. Extending expectation disconfirmation theory (EDT), we further distinguish among disconfirmed outcome, process, and cost expectancies as major consequences of e-commerce service failures. A theoretical model of e-commerce service failure classifications and their consequences was constructed together with testable propositions that relate the three failure categories to consumers' disconfirmed expectancies. Finally, we explore the validity of our theoretical model based on descriptive accounts of actual occurrences of e-commerce service failures and their corresponding consequences. Consistent with our theoretical model, information and functional failures were found to be associated with disconfirmed outcome and process expectancies respectively. System failures, on the other hand, do not affect consumers' disconfirmed expectancies, thereby contradicting our predictions. Post hoc analysis on constituent dimensions of information, functional, and system failures yielded additional insights on the preceding observations.
\end{abstract}

Keywords: E-commerce service failure, expectation disconfirmation theory, information failure, functional failure, system failure, disconfirmed outcome expectancy, disconfirmed process expectancy, disconfirmed cost expectancy, critical incident technique (CIT), qualitative comparative analysis (QCA)

\section{Introduction}

E-commerce service failures are common occurrences. In a review of contemporary websites spanning multiple indus-

\footnotetext{
${ }^{1}$ Ron Thompson was the accepting senior editor for this paper. J. J. Po-An Hseih served as the associate editor.

The appendices for this paper are located in the "Online Supplements" section of the MIS Quarterly's website (http://www.misq.org).
}

tries, Oneupweb (2010), a digital marketing agency, reported that e-commerce transactions exhibit an alarming $45 \%$ failure rate. Similar findings were documented in Harris Interactive's (2006) survey of 2,790 online consumers, revealing that $88 \%$ of consumers experienced problems when transacting online. The Harris Interactive survey further illustrated that e-commerce service failures negatively affect e-merchants by forcing $40 \%$ of online consumers to abandon transactions $(8 \%)$ or to switch to a physical competitor $(32 \%)$. These results were corroborated in Forrester Consulting's (2009) 
survey of 1,048 online shoppers: $79 \%$ of shoppers who encountered any form of e-commerce service failure will no longer purchase from the faulty website, $46 \%$ will develop a negative impression of the e-merchant, and $44 \%$ will notify friends and family of the negative experience. The business impact of e-commerce service failures is best exemplified by the outage of Amazon.com [http://www.amazon.com] on August 19, 2013, where it was estimated that a downtime of a mere 40 minutes cost the online retail giant USD $\$ 4.72$ million in lost sales (Parkhurst 2013).

Additionally, $91 \%$ of consumers who had experienced any form of e-commerce service failure stated that they were more likely to question e-merchants' ability to safeguard confidential personal information disclosed during online transactions (Harris Interactive 2006). This implies that failure in one aspect of an e-commerce transaction will produce a negative spillover effect, causing consumers to lose faith in other facets of the transactional process. This spillover could be attributed to the arousal of negative emotions during service failures that obstruct cognitive reasoning (McCollKennedy and Sparks 2003). Due to the spillover, e-commerce service failures may adversely affect e-businesses in general since consumers may be reluctant to engage in future online transactions as a consequence of earlier bad experiences.

Although research into service failure is gaining momentum within the marketing discipline as a determinant of customer satisfaction (e.g., Hess et al. 2007; Leong et al. 1997; Maxham and Netemeyer 2002), we have only a limited understanding of the phenomenon, especially with regard to e-commerce transactional environments (Holloway and Beatty 2003). This situation is even more apparent in the domain of information systems. A review of articles published in the field's eight most prominent journals ${ }^{2}$ from 2001 to 2013 indicates that research into e-commerce service failure is sparse as compared to the knowledge accumulated in the areas of e-service quality and system success.

E-commerce is distinct from offline retail in that the entire transaction is accomplished through web-enabled services (Cenfetelli et al. 2008). As the contact points between consumers and web technologies have increased, opportunities for e-commerce service failures have grown proportionally (Holloway and Beatty 2003). Specifically, e-commerce websites, due to their reliance on web technologies, are

\footnotetext{
${ }^{2}$ Journals from the "basket of eight" are European Journal of Information Systems, Information Systems Journal, Information Systems Research, Journal of Information Technology, Journal of Management Information Systems, Journal of Strategic Information Systems, Journal of the Association for Information Systems, and MIS Quarterly. (Reference: http://home. aisnet.org/displaycommon.cfm?an=1\&subarticlenbr=346)
}

extremely vulnerable to the aftermath of failure occurrences due to limited opportunities for physical intervention (Holloway and Beatty 2003). Consumers tend to participate in pseudo-relationships with multiple e-merchants and can readily switch among e-commerce websites with the mere click of a mouse button. For this reason, the majority of consumers, when confronted with e-commerce service failures, will choose to simply forsake the transaction and terminate their relationship with the e-merchant (Harris Interactive 2006). An in-depth appreciation of e-commerce service failures is therefore necessary to stem the tide of customer loss prevalent even among sophisticated e-merchants (Forrester Consulting 2009).

To bridge the aforementioned knowledge gaps, we drew on expectation disconfirmation theory (EDT) to conduct an exploratory study on the formation and impact of e-commerce service failure on online consumer behavior. Particularly, we synthesized prior research on e-service and system success to advance a novel classification system of e-commerce service failures that delineates failure incidents into information, functional, and system categories. Next, we contended that e-commerce service failure consequences can be demarcated according to whether they disconfirm consumers' outcome, process, or cost expectancies. A theoretical model of e-commerce service failure classifications and their consequences was then constructed together with testable propositions. This theoretical model was subjected to subsequent empirical validation through actual events of e-commerce service failures, which were elicited via an online survey fashioned after the critical incident technique (CIT). These events were scrutinized - through a combination of content analytical techniques, chi-square test and crisp-set qualitative comparative analysis (csQCA) - to examine whether relationships postulated in our theoretical model are representative of how e-commerce service failures manifest in reality. In doing so, this paper endeavors to provide answers to the following research questions:

1. What are e-commerce service failures and how do they manifest on e-commerce websites?

2. How will different types of e-commerce service failures impact consumers' evaluations of e-commerce websites?

\section{An Expectation Disconfirmation Perspective of E-Commerce Service Failure}

Consumers' expectations of e-commerce websites form the baseline from which evaluations about service performance 
are formulated (Bhattacherjee 2001). Consequently, service failures in offline contexts have been conceived as consumers' evaluations of service delivery falling below their expectations (e.g., Andreassen 2001; Bitner 1990; Maxham and Netemeyer 2002). The same rationale applies to e-commerce service failures. An e-commerce service encounter depicts the entire transactional process that begins when a consumer visits a website to query products or services to the moment when a product or service, which matches the consumer's needs, has been delivered to his/her satisfaction (Boyer et al. 2002). Because e-commerce transactions rely on the web-enabled interface as the focal point of contact between consumers and e-merchants (Gefen 2002), web technologies are indispensable in the provision of customer-centric self-service applications (Dabholkar 1996), which support consumers in accomplishing a full range of transactional activities (Bitner et al. 2000; Cenfetelli et al. 2008; Xu et al. 2013). Conceivably, an e-commerce service failure arises whenever an e-commerce website lacks the capabilities to offer even the minimum standard of service performance that a consumer expects and is willing to accept (Kettinger and Lee 2005). We therefore defined e-commerce service failure ${ }^{3}$ as a negative event that occurs whenever the e-commerce website is incapable of offering the necessary technological capabilities essential for a consumer to accomplish his/her transactional activities and/or objectives.

A review of extant literature uncovers four predominant trends that permeate past studies on service failures. First, even though several studies have attempted to advance a comprehensive classification system of service failures, the bulk of them, with the exception of Holloway and Beatty (2003), cater to offline circumstances and include failure dimensions that are not directly applicable to e-commerce transactional environments ${ }^{4}$ (see Bitner et al. 1994; Bitner et al. 1990; Keaveney 1995; Kelley et al. 1993 in Appendix A). Second, service failure classification systems advanced in the

\footnotetext{
${ }^{3}$ We do not presuppose that an e-commerce transaction has to terminate in the event of an e-commerce service failure. An e-commerce service failure could simply hinder the ability of a consumer to attain his/her transactional objectives (e.g., spend minimum time and effort when shopping online) rather than causing him/her to abandon the transaction midway. Such a definition aligns with that of Holloway and Beatty (2003), who found that consumers treat both fatal errors and inconveniences during online transactions equally as e-commerce service failures.

${ }^{4}$ Service failures identified the classifications by Bitner and colleagues (Bitner, Booms, and Mohr 1994; Bitner, Booms, and Tetreault 1990), Keaveney (1995), Kelley et al. (1993), as well as McColl-Kennedy and Sparks (2003) generally revolve around interactional conflicts between consumers and store employees (e.g., wrongful accusation of customers or failure in dealing with uncooperative customers) for which the probability of occurrence would be negligible in e-commerce transactional environments.
}

aforementioned studies, including that of Holloway and Beatty, were inductively derived and lacked theoretical grounding. This might account for why past classification studies of service failures typically fell short of identifying consequences for the failure dimensions proposed in these studies (see Appendix A). Conversely, among past studies that examined the consequences of service failures, the majority tend to treat failure as a unidimensional construct without taking into consideration its multifaceted nature (e.g., Colgate and Norris 2001; Hess et al. 2007; Maxham and Netemeyer 2002 in Appendix A). Third, past studies of service failure consequences were all situated within offline environments so much so that consequences theorized in these studies may not reflect the contextual uniqueness of e-commerce transactions (e.g., Colgate and Norris 2001; Hess et al. 2007; Maxham and Netemeyer 2002 in Appendix A). Finally, the number of service failure studies within the information systems discipline is disproportionate (see Appendix A) in comparison to the rich research stream in the area of system success under which the concept of service quality has been subsumed (see DeLone and McLean 1992, 2003).

Conceivably, the above trends underpin the urgency for recognizing e-commerce service failures as a conceptually distinct phenomenon that warrants its own research agenda. Not only are e-commerce service failures contextually distinguishable from their offline counterparts as mentioned earlier, they are also theoretically separable from the well-established paradigm of system success. Although e-commerce service failures share tenets of system success research in their emphasis on technological artifacts as enablers (or inhibitors) of task performance, discrepancies exist between the two. First, e-commerce service failure and system success are not necessarily opposites. Holloway and Beatty revealed the existence of e-commerce service failures for which no opposing positive could be found: consumers tend to equate unintentional errors committed during online transactions (e.g., entering the wrong quantity during web purchases or clicking on the payment button twice) with e-commerce service failures by blaming e-merchants for what are conceivably consumers' own mistakes. E-commerce service failures thus share characteristics of inhibitors, which Cenfetelli (2004) characterized as "perceptions held by a user about a system's attributes with consequent effects...that act solely to discourage use" (p. 475). By extension, e-commerce service failures are more strongly felt in their presence rather than their absence: "the presence of a given negative characteristic is more informative than its absence" (Cenfetelli 2004, p. 480; see also Gino and Pisano 2011).

Second, e-commerce service failures could give rise to consequences that are exclusive and distinguishable from those of system success. Whereas scholars have primarily attested to 
system success as predictors of customer satisfaction (see DeLone and McLean 1992, 2003; Xu et al. 2013), prior research on service failures has elucidated a much broader range of cognitive and emotional responses: anger (e.g., Taylor 1994), complaint (e.g., DeWitt and Brady 2003), dissatisfaction (e.g., Hess et al. 2007; Kelley et al. 1993), justice (e.g., Smith et al. 1999), regret (Tsiros and Mittal 2000) and uncertainty (Taylor 1994).

Third, prior research has shown that service failures are likely to invoke more enduring and temperamental responses from consumers due to the arousal of negative emotions (Andreassen 2001; McColl-Kennedy and Sparks 2003). In other words, system success, in the context of e-commerce transactions, is rooted in the capacity of self-service applications to deliver a rewarding customer service experience on a consistent and recurring basis (Cenfetelli et al. 2008; Xu et al. 2013). Conversely, e-commerce service failures deal primarily with undesirable exceptions that occur within a singular service encounter. ${ }^{5}$

Fourth, e-commerce service failures differ from system success in terms of intentionality. While e-merchants will actively pursue design elements of e-commerce websites that enable consumers to experience system success, they are unlikely to deliberately introduce flaws into their own websites (Cenfetelli 2004). Otherwise, persistent and systematic e-commerce service failures are likely to cause the demise of e-merchants (see Cenfetelli and Schwarz 2011).

To supplement our knowledge of systems success in individual e-commerce transaction encounters, we applied expectation disconfirmation theory (EDT) to construct a theoretical model of e-commerce service failure classifications and their consequences. In doing so, we derived a theoretically grounded classification system of e-commerce service failures and redefined what failure consequences would mean for online transactions. EDT was championed by Oliver $(1980,1981)$ as a theoretical framework for deciphering consumers' reactions to the performance of a product/service relative to their pre-consumption expectations. EDT posits that expectations, coupled with product/ service performance, determine consumers' post-consumption attitudes. This effect, in turn, is mediated by the disconfirmation of consumers' expectations through product/service performance. Depending on whether a product or service outperforms, performs, or underperforms relative to consumers' a priori expectations, the latter's expectations will be positively disconfirmed, confirmed, or negatively discon-

\footnotetext{
${ }^{5}$ We would like to thank an anonymous reviewer for pointing out this crucial distinction between e-commerce service failure and system success.
}

firmed. Because EDT encapsulates the cognitive process through which dissonance between expectations and performance shapes consumers' attitudes, it has been applied predominantly to investigate offline service failures (e.g., Bitner 1990; Maxham and Netemeyer 2002; Smith et al. 1999).

From the above discussion, we can infer that negatively disconfirmed expectations are implicit to service failures. Oliver and Swan (1989) revealed disconfirmation to be a key driver of customer satisfaction whereas Smith et al. (1999) testified to the existence of a causal relationship between service failures and disconfirmed expectations. The disconfirmation paradigm has also been corroborated by Bhattacherjee and Premkumar (2004), who showed that disconfirmed expectations affect technology acceptance even though users' expectations were not measured. Similarly, we exclude consumers' expectations in the construction of our theoretical model and, instead, focus solely on negatively disconfirmed expectations as immediate consequences of e-commerce service failures ${ }^{6}$ (see Figure 1). It should be noted that our decision to exclude considerations of expectations from our theorization was deliberate to align with our research objectives: while we seek to unravel the impact of e-commerce service failures on consumers, the basis on which such impact is being assessed is beyond the scope of this study.

\section{A System-Oriented Classification System of E-Commerce Service Failures}

According to Nickerson et al. (2013), a classification system captures the abstract groupings into which objects of interest are categorized whereas classification is reserved for the actual process of categorizing objects into these groupings. Likewise, Bailey (1994) employed the term classification to refer to the process of "ordering entities into groups or classes on the basis of similarity" (p. 1) and distinguished between conceptual and empirical approaches to classification in social

\footnotetext{
${ }^{6} \mathrm{By}$ anchoring our theorization of e-commerce service failures and their consequences on EDT, we subscribe to the view that such failures stem from the inability of e-merchants to perform at a level that befits consumers' $a$ priori expectations of service performance (see Andreassen 2001; Bitner 1990; Maxham and Netemeyer 2002; Smith et al. 1999). We do not make assumptions about an optimal level of performance for e-merchants that consumers should come to expect. Rather, e-commerce service failure, in the context of this study, is construed as a personalized situation in which a consumer experiences service performance at a level below his/her preconsumption expectation (i.e., negatively disconfirmed expectations).
} 
sciences. In the conceptual approach, the researcher starts with "a conceptual or theoretical foundation and then derives the [classification system] through deduction" (Nickerson et al. 2013, p. 339). Conversely, the empirical approach "starts with data and derives the classification from this data using cluster analysis or other statistical methods" (Nickerson et al. 2013 , p. 339). Yet, in spite of their divergence, the conceptual and empirical approaches to classification do not preclude each other. Rather, Bailey endorsed a blend of conceptual and empirical approaches to derive classification systems that are often much more informative. There are two options for blending conceptual and empirical approaches to classification. One is to begin with the conceptual approach by deriving a classification system with theoretically inspired groupings and then inspecting empirical instances to determine the extent to which they conform to these groupings (i.e., conceptual $\rightarrow$ empirical) (Bailey 1994). The other is to derive empirical clusters through data reduction and then label each cluster deductively (i.e., empirical $\rightarrow$ conceptual) (Bailey 1994). Of the two options, we opted for the conceptual over the empirical approach. We first derived an initial classification system with theoretically meaningful e-commerce service failure dimensions. This classification system was then subjected to empirical validation and refinement in order to compile an eventual collection of e-commerce service failure dimensions. Our integrative approach to deriving a classification system of e-commerce service failures is consistent with Nickerson et al., who professed that "the conceptual approach is not based on empirical data, although such data could be brought in toward the end of the process for verification purposes" (p. 339). The next section extends the e-service and system success research streams to derive an initial classification system of e-commerce service failures for empirical testing.

\section{E-Commerce Service Failures, Service Quality and System Success: A Synthesis}

According to EDT, consumers' evaluation of service quality acts as a precursor to determining whether service failures have occurred (e.g., Andreassen 2001; Bitner 1990; Maxham and Netemeyer 2002 Smith et al. 1999). We therefore built on the concept of service quality to establish prevailing standards of service performance for e-commerce websites, which, by their absence, constitutes instances of e-commerce service failures. The notion of service quality has emerged as a means for businesses to effectively differentiate from their primary competitors (see Parasuraman et al. 1985, 1988). Service quality captures a consumer's subjective assessment of his/her interaction with a service provider and reflects the extent to which his/her expectations of service performance have been met during the course of the interaction (Dabholkar et al. 2000; Parasuraman et al. 1985, 1988). Within the domain of information systems, service quality has been applied extensively to evaluate system success in relation to the level of support offered by IT departments to organizational clients (e.g., Jiang et al. 2002; Kettinger and Lee 2005). While organization-centric theorizations of service quality have dominated information systems research previously, recent developments in the field have called for a deeper appreciation of how e-services could be designed to better facilitate e-commerce transactions (Cenfetelli et al. 2008; Gefen 2002; Xu et al. 2013). Because technology deployment within e-commerce websites assumes the form of self-service applications (Straub and Watson 2001), studies have attested to the importance of service quality as a key determinant of consumers' satisfaction with online transactions (e.g., Cenfetelli et al. 2008; Xu et al. 2013). For this reason, it is up to e-merchants to experiment and discover ways by which e-commerce websites could deliver service performance standards that are comparable to or even exceed those of offline retail (Bitner 2001; Zeithaml et al. 2002). Hence, we turned to past studies on e-service quality to derive service performance standards, which, when absent, constitutes e-commerce service failures.

Our review of the e-service literature ${ }^{7}$ disclosed a diversity of service performance standards that have been advocated by scholars as being desirable for e-commerce transactions. While there appears to be general consensus among researchers on the instrumental role of e-commerce websites in guaranteeing consistency in the delivery of online transactional services through accessible, adaptable, fast, navigable, and secure interfaces (see Appendix B), they were divided over how information and web-enabled features (e.g., ordering, payment, and tracking functions) drive consumers' evaluations of service quality. Whereas several studies placed strong emphasis on the provision of web-enabled features to assist consumers at various stages of the e-commerce transactional process (e.g., Cenfetelli et al. 2008; Connolly et al. 2010; Tan et al. 2013), others promoted the value of informa-

\footnotetext{
${ }^{7}$ We reviewed articles from refereed journals in the information systems discipline that publish research in the area of e-commerce, namely E-Service Journal, European Journal of Information Systems, Information Systems Journal, Information Systems Research, International Journal of Electronic Commerce, Journal of the Association for Information Systems, Journal of Information Technology, Journal of Management Information Systems, Journal of Strategic Information Systems, and MIS Quarterly. We searched for articles published during the ten-year period (i.e., 2003 to 2013) on the topic of service quality in information systems. For each article extracted from the preceding journals, we scrutinized its bibliography section to identify additional publications that could be relevant. Through a cascading search of published articles on service quality, we strived to ensure a relatively comprehensive (but not necessarily exhaustive) coverage of the topic. In total, we located 59 articles (see Appendix B).
} 
tion in bringing about a rewarding service encounter (e.g., Agarwal and Venkatesh 2002; Petter et al. 2013; Xu et al. 2013). There are also scholars who declared information and web-enabled features to be equally important drivers of service quality for e-commerce websites (e.g., Benlian et al. 2011; Luo et al. 2012; Tate and Evermann 2010). Yet, these prescriptions of service performance standards exist at different levels of abstraction, ranging from broad design principles to specifics about exact web-enabled features to be implemented. This points to a pressing need to take stock of existing knowledge on service quality and lay the foundation for isolating causes of e-commerce service failures.

To reconcile these diverse prescriptions of service quality, we built on DeLone and McLean's $(1992,2003)$ system success model to derive a theoretically grounded classification system that characterizes transactional problems unique to e-commerce websites. DeLone and McLean (1992) distinguished between information and system attributes as key determinants of technological system success. Whereas information attributes represent the value of information generated by a technological system, system attributes are reflective of the system's technical performance (DeLone and McLean 1992). The relevance of information and system attributes in determining system success has been corroborated in numerous studies (e.g., Igbaria et al. 1997; Rai et al. 2002; Wixom and Todd 2005). With a growing emphasis on service technologies in the last decade, DeLone and McLean (2003) refined their original system success model to incorporate service attributes, thereby acknowledging the dual role of IS organizations as an "information provider (producing an information product)" and a "service provider (providing support for end user developers)" (p. 18). Extrapolated to the context of e-merchants, DeLone and McLean (2004) claimed that these service attributes assume the form of "on-line support capabilities, such as answers to frequently asked questions, customized site intelligence, and order tracking" (p. 37) on e-commerce websites.

Cenfetelli et al. (2008) introduced the concept of supporting service functionality to denote technological features that add value by supporting consumers throughout the e-commerce transactional process (see also Lightner 2004). Service functionalities are distinguishable from information and system attributes in that they take the form of self-service applications, which generate and tailor transactional support to match the requirements of individual consumers (Cenfetelli et al. 2008; Lightner 2004). For instance, requirements elicitation functionalities (e.g., recommendation agents) offer advice about products that best fit consumers' specifications whereas payment functionalities produce confirmation receipts verifying order details and tracking functionalities supply information on the current whereabouts of purchased products. Without direct interaction with human service providers, Grönroos et al. (2000) thus argued that e-commerce websites must be "functionally advanced enough and technically easy to operate by the customer so that he or she can get access to the service package" (p. 248). This lends credibility to the cruciality of functional attributes as focal elements of service quality for e-commerce websites (Janda et al. 2002).

Adapting DeLone and McLean's system success model, we therefore postulate that failures for e-commerce websites may be delineated into those associated with the information, functional, or system aspects of online transactions. Functional aspects parallel DeLone and McLean's (2003) service attributes in that these functionalities are on-line support capabilities that realize customer service. Our distinction among information, functional, and system attributes also resonates with Grönroos et al.'s conception of service quality as a mix of content and delivery elements (see also Tan et al. 2013). Whereas service content quality is concerned with the extent to which the combined information and functional aspects of a service aid consumers to obtain the outcomes they desire (Janda et al. 2002), service delivery quality relates to the manner by which customers can readily access this content (Tan et al. 2013). The remainder of this section explores information, functional, and system failures in-depth to arrive at viable working definitions and their constituent dimensions.

\section{Information Failures}

The saliency of information attributes in determining system output quality is well documented (DeLone and McLean 1992, 2003; Seddon 1997; Wixom and Todd 2005). Holloway and Beatty (2003) discovered that information failures (e.g., incorrect listing of out-of-stock items) capture a substantial fraction of technological problems that consumers associate with e-commerce websites. We therefore postulate that information failure constitutes a major deficiency of e-commerce websites and that it occurs whenever information provided on an e-commerce website hinders consumers in accomplishing their transactional activities and/or objectives. While scholars tend to disagree over a representational list of preferred information attributes (e.g., Wand and Wang 1996; Wang and Strong 1996), there is general consensus that accuracy, completeness, relevance, and timeliness are definitive of information quality (DeLone and McLean 1992, 2003; Wixom and Todd 2005). Hence, we posit that information failures on e-commerce websites are caused by inaccurate, incomplete, irrelevant, and/or untimely transactional information. 
Inaccurate Information: Within the system success literature, it is accepted that accurate information is a key determinant of information quality because it captures the extent to which information generated by a technological system is correct and unbiased (DeLone and McLean 1992, 2003; Wixom and Todd 2005). Similarly, past studies of e-service quality have demonstrated that information accuracy affects consumers' positive evaluation of e-commerce websites (Chiu et al. 2007; Collier and Bienstock 2003, 2006; $\mathrm{Xu}$ et al. 2013). It is thus not surprising that Holloway and Beatty alluded to inaccurate information as a pervasive form of e-commerce service failure.

Incomplete Information: As conceived by Wixom and Todd (2005), information is complete when a technological system provides all essential facts necessary for task performance. In the context of e-commerce transactions, Collier and Bienstock $(2003,2006)$ maintained that full information disclosure of product specifications, company policies, transactional procedures, and hidden charges is crucial to ensure transparency of and build consumers' confidence toward such transactions. Otherwise, incomplete information may mislead consumers into making satisficing or even harmful choices (Waite and Harrison 2002).

Irrelevant Information: McKinney et al. (2002) claimed that e-commerce websites deliver relevant information when the information that is provided is pertinent to consumers' purchase decisions. Conceivably, the presence of irrelevant information adds to the transactional burden of consumers by complicating the information search process unnecessarily: consumers will be forced to sift through large amounts of content to get at information relevant to the task at hand (Waite and Harrison 2002).

Untimely Information: Wixom and Todd defined information timeliness as the extent to which information generated by a technological system is up-to-date. Untimely information compromises the transactional performance of e-commerce websites by steering consumers toward erroneous purchase decisions (e.g., a consumer may purchase a hazardous product by mistake if the e-commerce website has been slow in releasing safety warnings about the product) (Collier and Bienstock 2003, 2006; Petter et al. 2013).

\section{Functional Failures}

Homburg et al. (2002) observed that the breadth and depth of service functionalities shape consumers' shopping experience by providing constant support throughout the entire transactional process (see also DeLone and McLean, 2003, 2004). The provision of timely assistance from pre- to post- transactional stages can be realized through web-enabled functionalities, especially in nurturing a personalized customer service experience (Cenfetelli et al. 2008; Lightner 2004; Tan et al., 2013). Within service failure literature, Holloway and Beatty (2003) identified ordering and payment difficulties to be persistent forms of functional failure experienced by consumers who transact via e-commerce websites. We hence defined functional failure to have occurred whenever functionalities provided on an e-commerce website are incapable of supporting consumers in accomplishing their transactional activities and/or objectives. In line with Jacoby's (1998) delineation of consumer decision making into five sequential activities (i.e., needs recognition, alternatives identification, alternatives evaluation, product acquisition, and post-purchase), we contend that functional failure may occur at any of these activities (see also Appendix B).

Needs Recognition Failure: Needs recognition failure occurs whenever e-commerce websites fail to provide functionalities that assist consumers to make sense of their needs and preferences (Cenfetelli et al. 2008; Lightner 2004; Tan et al. 2013). This is because functionalities supporting needs recognition serve three basic purposes: (1) to educate consumers about a product/service offered on an e-commerce website; (2) to get these consumers to realize how offerings from the website differ from those of its competitors; and (3) to aid consumers in selecting the product/service best suited to their requirements (Piccoli et al. 2001).

Alternatives Identification Failure: Although a consumer could have narrowed down (e.g., via recommendation agents) to a smaller subset of products/services he/she is interested in, he/she may still wish to search for alternate and/or related products/services (Ranganathan and Ganapathy 2002). Since lower cost of information search is a core benefit of electronic marketplaces, it is vital for e-commerce websites to offer functionalities to augment the search process (Cenfetelli et al. 2008; Luo et al. 2012; Tan et al. 2013). Functionalities like search engines help consumers to filter massive amounts of data on e-commerce websites to arrive at the required information (Ranganathan and Ganapathy 2002). Failure to provide functionalities, which consolidate data sources for easy referencing, would compound consumers' difficulty in identifying relevant alternatives.

Alternatives Evaluation Failure: Individuals typically employ a two-stage cognitive evaluation process in making decisions with complex parameters (Jedetski et al. 2002; Xiao and Benbasat 2007). Whereas the first stage involves the refinement and transformation of consumers' preferences into a subset of promising alternatives (i.e., needs recognition) (Xiao and Benbasat 2007), it is only through the second stage 
of in-depth comparisons among generated alternatives that consumers eventually come to a purchase decision (Jedetski et al. 2002). For a comparison of alternatives to be meaningful, e-commerce websites must provide functionalities (e.g., a comparison matrix) that organize evaluative criteria of product/service alternatives in an intuitive and easily comprehensible manner (Evanschitzky et al. 2004; Haubl and Trifts 2000).

Acquisition Failure: Acquisition pertains to functionalities that facilitate the completion of online transactions (Ives and Learmonth 1984; Ives and Mason 1990). Piccoli et al. (2001) stressed that technological functionalities can simplify the acquisition process by retaining consumer information (e.g., shipping and payment information), which can be reused for subsequent orders (see also Kim et al. 2006; Luo et al. 2012; Parasuraman et al. 2005). Acquisition failures (e.g., missing ordering and payment functions) are hence fatal to e-commerce websites, with payment errors being identified by Holloway and Beatty as the main inhibitor of online transactions.

Post-Purchase Failure: Post-purchase activities are those associated with product/service ownership and retirement. Ownership is geared toward assisting consumers in obtaining and maximizing the utility of purchased goods (Tan et al. 2013). Retirement is concerned with after-sales service and the clearance of products/services that have outlived their usefulness (Ives and Learmonth 1984; Ives and Mason 1990). Post-purchase functionalities include tracking services that monitor the status of purchase orders (Cenfetelli et al. 2008; Luo et al. 2012), FAQs that address common enquiries regarding the usage of purchased products (Douglas et al. 2003; Gounaris and Dimitriadis 2003), return centers that facilitate the refund of defective products (Connolly et al. 2010; Surjadjaja et al. 2003), and online auctions that support the disposal of unwanted products in a cost effective fashion (Piccoli et al. 2001). Unfair or unclear return policies have also surfaced as e-service failure dimensions in Holloway and Beatty's framework. Evidently, post-purchase functionalities are aimed at giving consumers ease of mind after purchases and their absence could constitute functional failures.

\section{System Failures}

System quality has been shown to streamline task performance through enhanced adaptability to changing requirements (Vandenbosch and Huff 1997; Wixom and Watson 2001). For online transactions, the absence of key system attributes may undermine the delivery of service content for e-commerce websites and lead to a complex transactional process for consumers (Cenfetelli et al. 2008; Tan et al.
2013). Holloway and Beatty's (2003) categorization of e-commerce service failures has similarly incorporated navigational difficulties as a core failure dimension. We hence defined system failure to have occurred whenever service content (i.e., information and functionalities) offered by an e-commerce website is not delivered in a conducive manner that facilitates consumers in accomplishing their transactional activities and/or objectives. Adapting DeLone and McLean's (2003) recommended metrics of system quality for successful e-commerce systems in conjunction with prevalent system attributes identified through our review of e-service literature (see Appendix B), we posit that system failures occur whenever e-commerce service content is inaccessible, non-adaptable, non-navigable, delayed, and insecure.

Inaccessibility: As e-merchants struggle to overcome physical limits during e-service delivery (Douglas et al. 2003; Janda et al. 2002; McKinney et al. 2002), diversity in the physiological capabilities of their target audience (e.g., dyslexia and visually impaired) and consumers' adoption of divergent technologies (e.g., PCs versus Macintoshes, or Internet Explorer versus Firefox) are sometimes overlooked as fundamental elements affecting the accessibility of e-commerce services (Shim et al. 2002). Consequently, accessibility has been hailed as one of the main service quality criteria for e-commerce websites (Surjadjaja et al. 2003; Tan et al. 2013; Xu et al. 2013). By the same logic, inaccessibility would count as a form of system failure for e-commerce websites.

Non-Adaptability: The strongest appeal of the Internet as an e-service delivery medium stems from its ability to automatically adapt transactional content to match consumers' circumstances such as the display of product catalogues in localized system languages or the pricing of products in domestic currency (DeLone and McLean 2003, 2004; Loiacono et al. 2007; Semeijn et al. 2005). Content adaptation on an e-commerce website, however, is contingent on whether e-services are delivered in a manner that facilitates dynamic engagement with their target audience (Carugati et al. 2005; Katz and Byrne 2003). Particularly, the capability of e-commerce websites to cope with diverse service content (e.g., multilingualism) and usage patterns (e.g., different conventions for data entry due to intercountry variations) plays a critical role in content adaptation (Evanschitzky et al. 2004; Palmer 2002; Srinivasan 2002; Surjadjaja et al. 2003). Otherwise, non-adaptable e-services may impose unnecessary constraints on consumers' transactional behaviors (Tan and Benbasat 2009).

Non-Navigability: The navigability of an e-commerce website governs the effort-performance expectancy of consumers (Childers et al. 2001; Tan and Benbasat 2009). The 
complexity of the navigational structure determines the ease by which an e-commerce website can be readily traversed by an inexperienced consumer and, ultimately, affects the amount of cognitive effort that must be expended by the consumer to accomplish his/her transactional task (Korthauer and Koubek 1994). Within extant literature, navigability has also emerged as a service performance standard for e-commerce websites (Barnes and Vidgen 2001; Childers et al. 2001; Meliàn-Alzola and Padron-Robaina 2006). Nonnavigability of e-commerce websites thus qualifies as a form of e-commerce service failure as asserted by Holloway and Beatty.

Delay: Response time acts as a major deterrence against consumers' adoption of e-commerce websites (Rose et al. 1999; Rose and Straub 2001; Torkzadeh and Dillon 2002). Past studies have discovered that long delays lead to complaints of frustration (Doherty and Kelisky 1979), feelings of dissatisfaction (Lee and MacGregor 1985), a sense of disorientation (Sears et al. 2000), and eventual abandonment (Nah 2002). Similar sentiments were expressed by Palmer (2002), who found download delays to be detrimental to e-commerce service encounters. Indeed, numerous studies have borne witness to the responsiveness of e-commerce websites as a hallmark of service quality (see also Devaraj et al. 2002; Gummerus et al. 2004; Kim and Lim 2001; Kim and Stoel 2004; O’Neill et al. 2001; Ribbink et al. 2004).

Insecurity: Security has received widespread attention within extant literature on e-service quality (e.g., Benlian et al. 2011; Santos 2003; Wolfinbarger and Gilly 2003; Zeithaml 2002; Zeithaml et al. 2002). Security in e-commerce websites pertains to protective measures to safeguard disclosed transactional data from unsanctioned or illegal intrusions by third parties and represents the first line of defense against abuse or misuse of confidential personal information (Collier and Bienstock 2003, 2006; Etezadi-Amoli and Farhoomand 1996). Holloway and Beatty also classified insecurity as a high priority failure for e-commerce websites.

Table 1 illustrates our proposed classification system of e-commerce service failures.

Appendix B maps information, functional, and system attributes in our classification system to past studies that have advocated similar attributes as being desirable qualities of e-services. It can be deduced from Appendix B that dimensions of information, functional, and system failures in our classification system are representative of potentially problematic areas for e-services. Our classification system, therefore, encompasses a generic collection of e-commerce service failure causes that are within e-merchants' abilities to rectify through improvements to web interface design. Also, in place of a wide-ranging array of failure categories and dimensions as depicted in contemporary frameworks (see Bitner et al. 1990, 1994; Keaveney 1995; Kelley et al. 1993), we chose to retain a concise but meaningful set of higherorder e-commerce service failure categories (i.e., information, functional, and system failures), each comprising lower-order dimensions of technological deficiencies. We believe that such a classification system could yield purposeful and targeted design prescriptions for service enhancements on e-commerce websites. Finally, our classification system circumvents the theoretical limitation of contemporary frameworks (i.e., Bitner et al. 1990, 1994; Holloway and Beatty 2003; Keaveney 1995; Kelley et al. 1993; McColl-Kennedy and Sparks 2003) by deductively deriving our e-commerce service failure classification system from the synthesis of e-service and system success literatures. This translates to a sturdier theoretical foundation from which to rationalize the causes and consequences of e-commerce service failures.

\section{An Expectation Disconfirmation Perspective of E-Commerce Service Failure Consequences}

Fundamental to service failure is the idea of expectation disconfirmation (Smith et al. 1999). However, EDT, in its current form, lacks sufficient explanatory and predictive power in modeling e-commerce service failure consequences. Despite the extensive application of EDT in investigating service failures (see Andreassen 2001; Bitner 1990; Maxham and Netemeyer 2002; Smith et al. 1999), no study has gone beyond theorizing disconfirmation as a monolithic construct. Without a thorough understanding of the consequences faced by consumers in the event of e-commerce service failures, e-merchants are unable to tailor recovery measures in ways that are commensurate to felt consequences (Smith et al. 1999). To uncover consequences of e-commerce service failure, we drew inspiration from Glover and Benbasat's (2010) work on risk in online consumption behavior.

Bauer's (1960) seminal work on risk-taking in consumption behavior put forth the idea that consumption behaviors should be construed as instances of risk-taking on the part of consumers:

consumer behavior involves risk in the sense that any action of a consumer will produce consequences which he cannot anticipate with anything approximating certainty, and some of which at least are likely to be unpleasant (Cox 1967, p. 24; see also Cox and Rich 1964). 


\begin{tabular}{|c|c|}
\hline Construct & Definition (Event in which...) \\
\hline \multicolumn{2}{|l|}{ Information Failures } \\
\hline Inaccurate Information & $\begin{array}{l}\text { Information provided on an e-commerce website contains errors that misinform consumers in } \\
\text { making transactional decisions }\end{array}$ \\
\hline Incomplete Information & $\begin{array}{l}\text { Information provided on an e-commerce website is insufficient to aid consumers in making } \\
\text { transactional decisions }\end{array}$ \\
\hline Irrelevant Information & $\begin{array}{l}\text { Information provided on an e-commerce website cannot be utilized by consumers in making } \\
\text { transactional decisions }\end{array}$ \\
\hline Untimely Information & $\begin{array}{l}\text { Information provided on an e-commerce website is not updated to support consumers in making } \\
\text { transactional decisions }\end{array}$ \\
\hline \multicolumn{2}{|l|}{ Functional Failures } \\
\hline $\begin{array}{l}\text { Needs Recognition } \\
\text { Failure }\end{array}$ & $\begin{array}{l}\text { Functionalities of an e-commerce website are incapable of assisting consumers to formulate their } \\
\text { needs and preferences for products and/or services }\end{array}$ \\
\hline $\begin{array}{l}\text { Alternatives } \\
\text { Identification Failure }\end{array}$ & $\begin{array}{l}\text { Functionalities of an e-commerce website are incapable of assisting consumers to search for } \\
\text { information on interested products and/or services }\end{array}$ \\
\hline $\begin{array}{l}\text { Alternatives Evaluation } \\
\text { Failure }\end{array}$ & $\begin{array}{l}\text { Functionalities of an e-commerce website are incapable of assisting consumers to draw } \\
\text { comparisons among interested products and/or services }\end{array}$ \\
\hline Acquisition Failure & $\begin{array}{l}\text { Functionalities of an e-commerce website are incapable of assisting consumers to acquire } \\
\text { desired products and/or services }\end{array}$ \\
\hline Post-Purchase Failure & $\begin{array}{l}\text { Functionalities of an e-commerce website are incapable of assisting consumers to: (1) keep } \\
\text { track of purchased products and/or services; (2) solicit advice on ways to maximize the utility of } \\
\text { purchased products and/or services, and; (3) dispose of unwanted products and/or services. }\end{array}$ \\
\hline \multicolumn{2}{|l|}{ System Failures } \\
\hline Inaccessibility & Services of an e-commerce website are not accessible \\
\hline Non-Adaptability & $\begin{array}{l}\text { Services of an e-commerce website are unable to accommodate diverse content and usage } \\
\text { patterns }\end{array}$ \\
\hline Non-Navigability & Services of an e-commerce website are difficult to navigate \\
\hline Delay & Services of an e-commerce website are inordinately slow in access \\
\hline Insecurity & $\begin{array}{l}\text { Services of an e-commerce website are not safeguarded against unsanctioned access by } \\
\text { unauthorized individuals }\end{array}$ \\
\hline
\end{tabular}

In the same vein, Santos and Boote (2003) conceded that no matter how many times a consumer has been exposed to the same service, their expectations of the next service encounter might still be violated due to the presence of unanticipated and/or uncontrollable factors. The same can be said for e-commerce transactions. Without the assurance of face-toface confirmation, past studies have claimed that risks for e-commerce transactions are comparable to, if not more pronounced than, their offline counterparts (e.g., Crespo et al. 2009; Featherman and Pavlou 2003; Lee 2009). Conceivably, e-commerce service failures are synonymous with occasions when risks associated with consumption behaviors are realized during online transactions (Webler et al. 1995). Taking a consumer standpoint, Cox (1967) identified three main categories of transactional risks that confront consumers: (1) not gaining that which one is trying to gain; (2) having to pay a penalty for trying to make the gain; and
(3) losing the means by which one hopes to make the gain (p. 37). Cox's (1967) typology has been adapted by Glover and Benbasat (2010) to the context of e-commerce transactions. They argued that e-commerce transactions expose consumers to the risk of (1) getting undesired outcomes, (2) expending unnecessary costs, and (3) encountering process disruptions. This distinction among outcome, process, and cost elements of e-commerce transactions resonates with past studies of cost-benefit analysis in technology usage.

As noted by Davis et al. (1992), cost-benefits associated with technology usage are rooted in (1) the capacity of the technology to produce desired task outcomes, as well as (2) the tangible and intangible costs that must be expended by individuals in utilizing the technology. Going beyond the outcome and cost associated with service utilization, there is ample evidence to suggest that the servicing process should 
not be neglected as a crucial element of e-commerce transactions (e.g., Collier and Bienstock 2003, 2006). Berry et al. (1985) differentiated between process and outcome in conceptualizing services (see also Collier and Bienstock 2003, 2006; Fassnacht and Koese 2006). They argued that the servicing process depicts consumers' interactive exchange with a service, whereas service outcome is the output from the execution of the service.

Similarly, Jacoby (1998) divided consumers' product acquisition process into five sequential stages (i.e., needs recognition, alternatives identification, alternatives evaluation, product acquisition, and post-purchase) and maintained that the provision of services to move transactional activities seamlessly along these stages is the key to fulfilling consumers' expectations (Ranganathan and Ganapathy 2002). Arguably, consumers are likely to possess expectations about how transactional processes should flow on e-commerce websites and these expectations are disconfirmed whenever they encounter disruptions to their transactions due to the presence of e-commerce service failures.

Like Glover and Benbasat, we distinguished among outcome, process, and cost as distinct expectations that consumers harbor toward service utilization. In turn, e-commerce service failures would lead to the disconfirmation of the aforementioned expectancies:

1. Disconfirmed outcome expectancy manifests whenever the transactional outcome(s) obtained from the e-commerce website is not what is desired by the consumer.

2. Disconfirmed process expectancy manifests whenever the transactional process on the e-commerce website does not proceed in a manner expected by the consumer.

3. Disconfirmed cost expectancy manifests whenever a consumer expends more resources than anticipated in transacting via an e-commerce website.

Figure 1 depicts our proposed theoretical model of e-commerce service failure classifications and their consequences.

\section{Consequences of E-Commerce Service Failures: An Expectancy Perspective}

A basic tenet of consumer behavior theory holds that when consumers make purchase decisions, the type of information is pivotal to the formation of decisional outcomes (Keaveney and Parthasarathy 2001; Muthukrishnan and Chattopadhyay
2007). As confirmed through existing studies of customer satisfaction and service quality, the information employed by consumers in making choice decisions influences outcome predictability (e.g., Oliver 1997; Yi 1990; Zeithaml et al. 1993, 1996). It is for this reason that information manipulation is deemed as the most persuasive mode of online deception in tempting consumers to undertake purchase decisions they would not have otherwise considered (Xiao and Benbasat 2011). If inaccurate and/or incomplete information were to be supplied by an e-commerce website, regardless of intentionality, consumers may be misled into acquiring products that do not match their requirements (Xiao and Benbasat 2011). Likewise, Collier and Bienstock (2003, 2006) have attested to information attributes (e.g., accuracy and timeliness) as crucial antecedents of service outcome quality. Although information failures may also adversely affect consumers' transactional processes and costs (e.g., confusing procedural instructions may disrupt the flow of transactional activities and lead to unnecessary time spent on completing the transaction), the saliency of information attributes in contributing to task outcomes is well documented within system success (e.g., DeLone and McLean 1992, 2003, 2004; Ives et al. 1983; Wixom and Todd 2005) and service failure literature (e.g., Gershoff et al. 2001; Holloway and Beatty 2003). We therefore posit that

\section{Proposition 1: While information failures within an e-commerce website will be associated with con- sumers' disconfirmed outcome, process, and cost expectancies, the association will be stronger for disconfirmed outcome expectancy.}

Functional failures cause dissonance to manifest in e-commerce transactional processes. Empirical findings suggest that service functionalities, no matter how well designed they may be, are rendered meaningless if they cannot satisfy consumers' transactional requirements (Cenfetelli et al. 2008; Luo et al. 2012; Singh 2002; Tan et al. 2013). The same opinion was expressed by Piccoli et al. (2001), who proclaimed that one must "think creatively about how technology can be integrated into your products and into your customer's experience" (p. 45) because the most innovative e-services are those that can effectively satisfy consumers' needs. E-commerce websites, in this sense, should not only mirror physical retailers in the range and sophistication of services being offered to consumers, but must also make available transactional functionalities, which are otherwise impractical via conventional media (Barnes and Vidgen 2001; Homburg et al. 2002). Studies conducted in both e-commerce (Cenfetelli et al. 2008) and e-government (Tan et al. 2013) domains have illustrated that consumers' service expectations for online transactions are not only distinguishable from those for their offline counterparts, but that these expectations also 


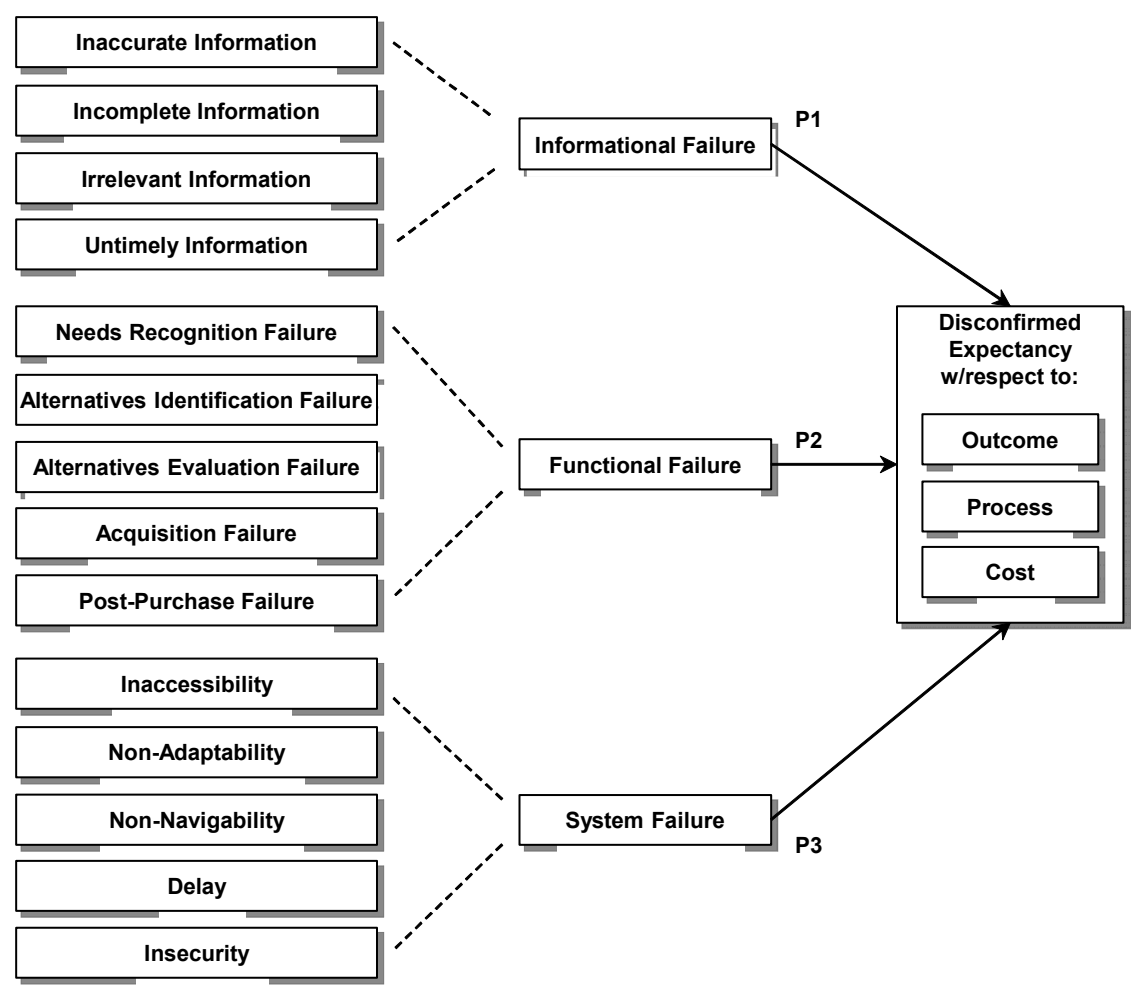

Figure 1. Theoretical Model of E-Commerce Service Failure Classifications and Their Perspective

vary depending on which stage of the transactional process consumers are currently engaged. The availability of complementary web-enabled functionalities to cater to the spectrum of service expectations throughout the online transactional process is, therefore, deterministic of an e-commerce website's eventual acceptance by its target audience (Cenfetelli et al. 2008; Lightner 2004). For instance, while recommendation agents are probably needed in the beginning of an e-commerce transaction to assist consumers in product selection, ordering and payment functions become salient in the later stages for product acquisition purposes. Likewise, Ranganathan and Ganapathy (2002) asserted that e-commerce transactions can be viewed as a sequence of stages for which ample support should be provided to assist consumers at every stage. In the absence of a seamless transactional process, consumers may be deterred from completing the e-commerce transaction. This could be one reason why Interactive Media Retail Group's (IMRG) (2012) survey of 53 online retailers in the United Kingdom revealed dismal conversion rates of $8 \%$ for "visit to add to basket" and 4\% for "visit to sale." Beyond transactional processes, functional failures may also negatively impact the outcome and cost of e-commerce transactions (e.g., missing recommendation agent may force customers to spend way more time than expected to locate desired products and, even then, these products may not be the ones that best match consumer requirements). However, in contrast to recent evidence that alludes to the decisive role of service functionalities in sustaining a fluid transactional process (e.g., Cenfetelli et al. 2008; Luo et al. 2012; Tan et al. 2013), there is comparatively less support for the negative impact of functional failures on outcome and cost. We therefore posit that

Proposition 2: While functional failures within an e-commerce website will be associated with consumers' disconfirmed outcome, process and cost expectancies, the association will be stronger for disconfirmed process expectancy.

As soon as a consumer visits an e-commerce website, he/she already begins to incur a cost for the transaction, be it effort expended or time spent. Because system attributes affect the efficiency with which consumers can access service content on an e-commerce website (DeLone and McLean 2003; Wixom and Todd 2005), it is inevitable that the presence of system failures lowers consumers' effort-performance expectancy as a much higher transactional cost must now be incurred to attain satisfactory service performance (Venkatesh 
et al. 2003). There is strong empirical justification for such a relationship. Prior research has identified an inverse relationship between response time and the amount of resources invested by system users (Barber and Lucas 1983; Martin and Corl 1986). Studies have shown that delays on e-commerce websites induce a sense of loss in consumers because they are forced to spend way more time than projected in accomplishing online transactions (Dellaert and Kahn 1999; Lee and MacGregor 1985; Sears et al. 2000). Nah (2002) further demonstrated that in the worst case scenario, consumers would rather terminate the transaction than waste time on unbearably slow e-commerce websites. Besides response time, there are other system attributes that have been cited within e-service literature as influential factors affecting consumers' transactional burden such as accessibility (e.g., Nath and Singh 2010; Surjadjaja et al. 2003; Tan et al. 2013; $\mathrm{Xu}$ et al. 2013), adaptability (e.g., Agarwal and Venkatesh 2002; DeLone and McLean 2003, 2004) and navigability (e.g., Barnes and Vidgen 2001; Childers et al. 2001; Loiacono et al. 2002, 2007). While system failures may also disconfirm consumers' outcome and process expectancies (e.g., nonadaptive service content may disrupt the flow of transactional activities and inhibit consumers from purchasing desired products), the impact of system attributes on transactional costs has received broad consensus among researchers. We therefore posit that

Proposition 3: While system failures within an e-commerce website will be associated with consumers' disconfirmed outcome, process and cost expectancies, the association will be stronger for disconfirmed cost expectancy.

\section{Methodology}

Due to the exploratory nature of our research objectives, we opted for a qualitative field survey with data collection strategies that are adapted from the critical incident technique (CIT). The survey was designed to elicit failure incidents that stemmed from consumers' prior experiences with e-commerce websites. CIT comprises four sequential steps: (1) deciding the objectives of the activity; (2) formulating plans and agendas for the collection of critical incidents; (3) gathering and analyzing data; and (4) interpreting empirical findings (Flanagan 1954). The primary advantage of CIT lies in "its capacity to provide accurate and consistent interpretations of people's accounts of events without depriving these accounts of their power or eloquence" (Viney 1983, p. 560). Although CIT is originally targeted at facilitating accurate retrospective recollection of events from experts in a particular role, it has been employed as a means of eliciting incidents of offline service failures in various hospitality and retailing industries (see Bitner et al. 1990, 1994; Hoffman et al. 1995; Kelley et al. 1993; Warden et al. 2003). Because CIT is devised to gather facts about what transpired before, during, and after an incident (Viney 1983), it is robust in capturing details of nonroutine and memorable events like e-commerce service failures. The reliability of CIT has also been verified in past information systems studies (see Majchrzak et al. 2005; Thomas and Bostrom 2010a, 2010b). A qualitative field survey that incorporates event recollection techniques from CIT should encourage better recall of failure incidents from respondents.

We conceived a critical incident as any event, combination of events, or series of events between a consumer and an e-commerce website that causes the former to experience failure in his/her usage of e-commerce services while performing an online transaction. Critical incidents were defined broadly to cast a wide net to ensure an adequate coverage of probable technological deficiencies across e-commerce websites. Respondents could report failure incidents along any stage of the online transactional process or on any aspect of the website. A detailed description of questionnaire development and survey protocol can be found in Appendix C.

By incorporating CIT into our qualitative field survey, we were able to obtain descriptive data on causes and consequences of e-commerce service failures. Armed with this descriptive data, we can retrospectively reconstruct scenarios of e-commerce service failures that arose from respondents' interactions with e-commerce websites (Serenko 2006). A pretest was conducted with a convenience sample of faculty members and graduate students from a large North American university. No major issues surfaced during the pretest.

\section{Data Collection}

Invitations were e-mailed to members belonging to a nationwide panel of e-business consumers from a commercial marketing research firm. In exchange for their participation, the marketing research firm awarded participating panel members points that can be redeemed for prizes. Following the study by Cenfetelli et al. (2008), we reviewed the computer logs of the web server on which the electronic survey was hosted. The server logs recorded 991 visits to the online questionnaire. Using the filtering question inserted at the start of the questionnaire to identify respondents who had experienced e-commerce service failure(s), 233 out of the 991 visitors to the survey satisfied our sampling criteria, thereby yielding a conservative estimate of $23.5 \%$ response rate.

Flanagan (1954, p. 340) suggested that 


\begin{tabular}{|c|c|c|c|c|c|c|c|}
\hline \multirow{2}{*}{$\begin{array}{l}\text { Demographic } \\
\text { Characteristic }\end{array}$} & \multirow{2}{*}{$\begin{array}{c}\text { No. of } \\
\text { Respondents } \\
\text { [\%] }\end{array}$} & \multirow[b]{2}{*}{ Comparison ${ }^{\ddagger}$} & \multirow{2}{*}{$\begin{array}{l}\text { Frequency of E-Commerce } \\
\text { Website Visitations }\end{array}$} & \multicolumn{4}{|c|}{$\begin{array}{l}\text { E-commerce service failure } \\
\text { [Total Incidents }=316]\end{array}$} \\
\hline & & & & 1 & 2 & 3 & Total \\
\hline \multicolumn{8}{|l|}{ Gender } \\
\hline Male & $132[62.56 \%]$ & $34 \%$ & At least once per 2 weeks & 90 & 20 & 22 & 196 \\
\hline Female & $79[37.44 \%]$ & $66 \%$ & At least once per 2 weeks & 53 & 11 & 15 & 120 \\
\hline \multicolumn{8}{|l|}{ Age } \\
\hline Age 19-29 & 32 [15.16\%] & $10 \%$ & At least once per 2 weeks & 26 & 1 & 5 & 43 \\
\hline Age $30-49$ & $86[40.76 \%]$ & $60 \%$ & At least once per 2 weeks & 62 & 10 & 14 & 124 \\
\hline Age 50-64 & $71[33.65 \%]$ & $28 \%$ & At least once per 2 weeks & 42 & 12 & 17 & 117 \\
\hline Age 65+ & 20 [9.48\%] & $2 \%$ & At least once per month & 11 & 8 & 1 & 30 \\
\hline Unwilling to disclose & $2[0.01 \%]$ & $0 \%$ & At least once per week & 2 & 0 & 0 & 2 \\
\hline \multicolumn{8}{|l|}{ Educational Level } \\
\hline $\begin{array}{l}\text { College education or } \\
\text { higher }\end{array}$ & 160 [75.83\%] & $87 \%$ & At least once per 2 weeks & 103 & 25 & 32 & 249 \\
\hline $\begin{array}{l}\text { Less than college } \\
\text { education }\end{array}$ & 49 [23.22\%] & $13 \%$ & At least once per 2 weeks & 38 & 6 & 5 & 65 \\
\hline Unwilling to disclose & $2[0.01 \%]$ & $0 \%$ & At least once per month & 2 & 0 & 0 & 2 \\
\hline \multicolumn{8}{|l|}{ Income } \\
\hline$\$ 0-\$ 29,999$ & 68 [32.23\%] & $15 \%$ & At least once per month & 48 & 10 & 10 & 98 \\
\hline$\$ 30,000-\$ 50,000$ & $50[23.70 \%]$ & $24 \%$ & At least once per 2 weeks & 34 & 8 & 8 & 74 \\
\hline$\$ 50,000-\$ 75,000$ & 39 [18.48\%] & $28 \%$ & At least once per 2 weeks & 28 & 6 & 5 & 55 \\
\hline$\$ 75,000+$ & $44[20.85 \%]$ & $33 \%$ & At least once per 2 weeks & 29 & 4 & 11 & 70 \\
\hline Unwilling to disclose & $10[0.05 \%]$ & $0 \%$ & At least once per week & 4 & 3 & 3 & 19 \\
\hline
\end{tabular}

${ }^{\ddagger}$ Cenfetelli et al. (2008)

if full and precise details are given, it can usually be assumed that this information is accurate. Vague reports suggest that the incident is not well remembered and that some of the data may be incorrect.

Accordingly, responses from 22 respondents were judged to be ambiguous and removed, leaving a final sample of 211 respondents for data analysis. Table 2 summarizes the descriptive statistics for the sample together with a breakdown of the number of e-commerce service failure incidents reported by various demographic groups. Paired $t$-tests between our sample demographics and those documented in Cenfetelli et al.'s survey of 1,235 consumers on the service quality of e-commerce websites reveal no significant differences in distribution (i.e., $t_{(14)}=-0.118, p=.907$ ).

A total of 316 e-commerce service failure incidents were reported by the respondents. Table 3 gives a detailed breakdown of the e-merchants and elapsed time for these 316 e-commerce service failures.
For each of the 316 e-commerce service failure incidents, the purpose of the visit was incorporated into the description of the incident when necessary. Additionally, an independent graduate student was hired to correct each incident for grammatical and spelling errors if any. Of these 316 incidents, 58 (or 18\%) contain descriptions of two distinct e-commerce service failure episodes within a single recall and are therefore split into separate incidents to prevent confounds from surfacing during data analysis. An example of such recollection is as follows:

Incident: "I wanted to buy a plane ticket online. I was able to choose the destination, date, and started placing the order, then to realize later that: [1] the price changed during the time I was completing the order, and [2] the website doesn't accept my credit card."

To avoid the loss of valuable contextual information, we segregated the aforementioned description into two separate incidents in the manner below: 


\begin{tabular}{|c|c|c|c|c|c|c|}
\hline Type of E-Merchant & $\begin{array}{l}\text { Less than } 1 \\
\text { month ago }\end{array}$ & $\begin{array}{l}\text { Less than } 3 \\
\text { months ago }\end{array}$ & $\begin{array}{l}\text { Less than } 6 \\
\text { months ago }\end{array}$ & $\begin{array}{l}\text { Less than } \\
1 \text { year ago }\end{array}$ & $\begin{array}{l}\text { More than } \\
1 \text { year ago }\end{array}$ & Total \\
\hline Online book store & $6[1.90 \%]$ & 7 [2.22\%] & 7 [2.22\%] & 3 [0.95\%] & $2[0.63 \%]$ & 25 [7.91\%] \\
\hline \multirow[t]{2}{*}{ Online clothing store } & 2 [0.63\%] & 2 [0.63\%] & 8 [2.53\%] & 3 [0.95\%] & 1 [0.32\%] & 16 [5.06\%] \\
\hline & $4[1.27 \%]$ & $4[1.27 \%]$ & $6[1.90 \%]$ & $5[1.58 \%]$ & $3[0.95 \%]$ & 22 [6.96\%] \\
\hline Online music/video store & $6[1.90 \%]$ & $3[0.95 \%]$ & 9 [2.85\%] & $1[0.32 \%]$ & $1[0.32 \%]$ & 20 [6.33\%] \\
\hline Online game store & 9 [2.85\%] & $0[0.00 \%]$ & 2 [0.63\%] & $2[0.63 \%]$ & 3 [0.95\%] & 16 [5.06\%] \\
\hline Online banking & $25[7.91 \%]$ & 11 [3.48\%] & 16 [5.06\%] & 6 [1.90\%] & 2 [0.63\%] & 60 [18.99\%] \\
\hline Online travel & $1[0.32 \%]$ & $0[0.00 \%]$ & $4[1.27 \%]$ & $1[0.32 \%]$ & $1[0.32 \%]$ & 7 [2.22\%] \\
\hline Online ticketing & $0[0.00 \%]$ & $0[0.00 \%]$ & $3[0.95 \%]$ & $1[0.32 \%]$ & $1[0.32 \%]$ & 5 [1.58\%] \\
\hline Online news & 9 [2.85\%] & 6 [1.90\%] & 4 [1.27\%] & 1 [0.32\%] & 0 [0.00\%] & 20 [6.33\%] \\
\hline Online auction & $2[0.63 \%]$ & $8[2.53 \%]$ & 7 [2.22\%] & $1[0.32 \%]$ & $5[1.58 \%]$ & $23[7.28 \%]$ \\
\hline Others $^{\ddagger}$ & $31[9.81 \%]$ & $18[5.70 \%]$ & $38[12.03 \%]$ & $5[1.58 \%]$ & $10[3.16 \%]$ & $102[32.28 \%]$ \\
\hline Total & 95 [30.06\%] & 59 [18.67\%] & 104 [32.91\%] & 29 [9.18\%] & 29 [9.18\%] & 316 [100.00\%] \\
\hline
\end{tabular}

${ }^{\ddagger}$ Other transactions include online florist, online gift store, online grocery store, online drug store, online office supplies and online porn among others.

Incident A: "I wanted to buy a plane ticket online. I was able to choose the destination, date, and started placing the order, then to realize later that the price changed during the time I was completing the order."

Incident B: "I wanted to buy a plane ticket online. I was able to choose the destination, date, and started placing the order, then to realize later that the website doesn't accept my credit card."

After splitting the 58 incidents, we ended up with a final sample of 374 data points for analysis.

\section{Data Analysis}

Data analysis was divided into three phases. In the first phase, content analysis was carried out to sort the sample of 374 incidents into our proposed e-commerce service failure classification system as outlined earlier. Intra- and inter-judge reliabilities were compared to ascertain the validity of our classification system in characterizing e-commerce service failures. In the second phase, content analysis was performed to sort descriptive accounts of e-commerce service failure consequences according to whether each reflects disconfirmed outcome, process, or cost expectancy. In the final phase, chisquare test and csQCA were performed to explore the impact of e-commerce service failures on consumers' disconfirmed expectancies.

\section{Content Analysis for E-Commerce Service Failure Incidents}

We adhered to a set of content analytical procedures for e-commerce service failure incidents that are in line with previous recommendations for CIT studies (see Boyatzis 1998; Butterfield et al. 2005; Keaveney 1995). Appendix D contains detailed description of the content analytical procedures for e-commerce service failure incidents. Our preliminary classification of the entire sample of 374 e-commerce service failure incidents by two judges is highly credible with an intra-reliability figure of 0.89 , an inter-reliability score of 0.88 and a Cohen's Kappa ${ }^{8}$ value of 0.87 .

Appendix E contains a detailed breakdown of how incidents have been categorized for failure dimensions within our classification system. As can be seen in Appendix E, the sorting exercise by the judges generated three additional failure dimensions (i.e., mischarging, product delivery problems, and unresponsive to customer enquiries) for our classification system which we grouped under a newly created higher-order category of "Nontechnological Failures." Essentially, these nontechnological failures correspond to failure incidents that are not technologically motivated and relate more to business malpractices of e-merchants as interpreted by the judges.

\footnotetext{
${ }^{8}$ Cohen's Kappa assesses agreement between judges by taking into account probabilities of chance agreement. The commonly acceptable threshold for Kappa is 0.70 (Cohen 1968).
} 


\begin{tabular}{|c|c|c|c|c|c|}
\hline Construct & $\begin{array}{l}\text { Failure } \\
\text { Incidents }\end{array}$ & $\begin{array}{l}\text { Disconfirmed } \\
\text { Outcome } \\
\text { Expectancy }\end{array}$ & $\begin{array}{l}\text { Disconfirmed } \\
\text { Process } \\
\text { Expectancy }\end{array}$ & $\begin{array}{l}\text { Disconfirm } \\
\text { ed Cost } \\
\text { Expectancy }\end{array}$ & $\begin{array}{c}\text { No } \\
\text { Disconfirmed } \\
\text { Expectancy }\end{array}$ \\
\hline Information Failure & $85[22.73 \%]$ & $53[14.17 \%]$ & $14[3.74 \%]$ & $18[4.81 \%]$ & $0[0 \%]$ \\
\hline Inaccurate Information & $28[7.49 \%]$ & $20[5.35 \%]$ & $4[1.07 \%]$ & $4[1.07 \%]$ & $0[0 \%]$ \\
\hline Incomplete Information & $21[5.61 \%]$ & $13[3.48 \%]$ & $5[1.34 \%]$ & $3[0.8 \%]$ & $0[0 \%]$ \\
\hline Irrelevant Information & $11[2.94 \%]$ & $3[0.8 \%]$ & $1[0.27 \%]$ & $7[1.87 \%]$ & $0[0 \%]$ \\
\hline Untimely Information & $25[6.68 \%]$ & $17[4.55 \%]$ & $4[1.07 \%]$ & $4[1.07 \%]$ & $0[0 \%]$ \\
\hline Functional Failures & 89 [23.8\%] & $26[6.95 \%]$ & $51[13.64 \%]$ & $5[1.34 \%]$ & $7[1.87 \%]$ \\
\hline Needs Recognition Failure & $3[0.8 \%]$ & $0[0 \%]$ & $3[0.8 \%]$ & $0[0 \%]$ & $0[0 \%]$ \\
\hline Alternatives Identification Failure & $8[2.14 \%]$ & $2[0.53 \%]$ & $4[1.07 \%]$ & $2[0.53 \%]$ & $0[0 \%]$ \\
\hline Alternatives Evaluation Failure & $1[0.27 \%]$ & $0[0 \%]$ & $1[0.27 \%]$ & $0[0 \%]$ & $0[0 \%]$ \\
\hline Acquisition Failure & $55[14.71 \%]$ & $9[2.41 \%]$ & 39 [10.43\%] & $2[0.53 \%]$ & $5[1.34 \%]$ \\
\hline Post-Purchase Consultation Failure & $22[5.88 \%]$ & $15[4.01 \%]$ & $4[1.07 \%]$ & $1[0.27 \%]$ & $2[0.53 \%]$ \\
\hline System Failures & $148[39.57 \%]$ & $22[5.88 \%]$ & $62[16.58 \%]$ & $57[15.24 \%]$ & $7[1.87 \%]$ \\
\hline Inaccessibility & $69[18.45 \%]$ & $7[1.87 \%]$ & $46[12.3 \%]$ & $12[3.21 \%]$ & $4[1.07 \%]$ \\
\hline Non-Scalability & $17[4.55 \%]$ & $1[0.27 \%]$ & $10[2.67 \%]$ & $5[1.34 \%]$ & $1[0.27 \%]$ \\
\hline Non-Navigability & $24[6.42 \%]$ & $5[1.34 \%]$ & $3[0.8 \%]$ & $15[4.01 \%]$ & $1[0.27 \%]$ \\
\hline Delay & $31[8.29 \%]$ & $3[0.8 \%]$ & $2[0.53 \%]$ & $25[6.68 \%]$ & $1[0.27 \%]$ \\
\hline Insecurity & $7[1.87 \%]$ & $6[1.6 \%]$ & $1[0.27 \%]$ & $0[0 \%]$ & $0[0 \%]$ \\
\hline Nontechnological Failures & $52[13.9 \%]$ & $37[9.89 \%]$ & $6[1.6 \%]$ & $4[1.07 \%]$ & 5 [1.34\%] \\
\hline Mischarging & $13[3.48 \%]$ & $8[2.14 \%]$ & $2[0.53 \%]$ & $1[0.27 \%]$ & $2[0.53 \%]$ \\
\hline Product Delivery Problems & $28[7.49 \%]$ & $21[5.61 \%]$ & $3[0.8 \%]$ & $1[0.27 \%]$ & $3[0.8 \%]$ \\
\hline $\begin{array}{l}\text { Unresponsive to Customer } \\
\text { Enquiries }\end{array}$ & 11 [2.94\%] & 8 [2.14\%] & 1 [0.27\%] & 2 [0.53\%] & 0 [0\%] \\
\hline Grand Total & $374[100 \%]$ & $138[36.90 \%]$ & $133[35.56 \%]$ & $84[22.46 \%]$ & $19[5.08 \%]$ \\
\hline
\end{tabular}

Table 5. Statistical Deviation of Observed Data from Expectation (Observed - Expected)

\begin{tabular}{|l|c|c|c|c|}
\hline $\begin{array}{c}\text { Disconfirmed } \\
\text { Expectancy }\end{array}$ & $\begin{array}{c}\text { Disconfirmed } \\
\text { Outcome Expectancy }\end{array}$ & $\begin{array}{c}\text { Disconfirmed } \\
\text { Process } \\
\text { Expectancy }\end{array}$ & $\begin{array}{c}\text { Disconfirmed } \\
\text { Cost Expectancy }\end{array}$ & $\begin{array}{c}\text { No Disconfirmed } \\
\text { Expectancy }\end{array}$ \\
\hline Information Failures & 21.6 & -16.2 & -1.1 & -4.3 \\
\hline Functional Failures & -6.8 & $\mathbf{1 9 . 4}$ & -15.0 & 2.5 \\
\hline System Failures & -32.6 & 9.4 & $\mathbf{2 3 . 8}$ & -0.5 \\
\hline Nontechnological Failures & 17.8 & -12.5 & -7.7 & 2.4 \\
\hline
\end{tabular}

\section{Table 6. fs/QCA Truth Table on Disconfirmed Outcome Expectancy}

\begin{tabular}{|c|c|c|c|c|c|c|}
\hline $\begin{array}{c}\text { Information } \\
\text { Failure }\end{array}$ & $\begin{array}{c}\text { Functional } \\
\text { Failure }\end{array}$ & $\begin{array}{c}\text { System } \\
\text { Failure }\end{array}$ & $\begin{array}{c}\text { Nontechnologic } \\
\text { al Failure }\end{array}$ & $\begin{array}{c}\text { Number of } \\
\text { Incidents }\end{array}$ & $\begin{array}{c}\text { Disconfirme } \\
\text { d Outcome }\end{array}$ & Consistency \\
\hline 1 & 0 & 0 & 0 & 85 & 1 & 0.624 \\
\hline 0 & 1 & 0 & 0 & 89 & 0 & 0.292 \\
\hline 0 & 0 & 1 & 0 & 148 & 0 & 0.149 \\
\hline 0 & 0 & 0 & 1 & 52 & 1 & 0.712 \\
\hline
\end{tabular}


To employ the chi-square test and csQCA in establishing correlations between distinct e-commerce service failure dimensions and consumers' disconfirmed expectancies, every data point (or e-commerce service failure incident) should correspond to one and only one failure dimension in our classification system. A series of follow-up interviews was conducted with the two judges to attain consensus on the placement of each failure incident. Content analysis for e-commerce service failure incidents was completed when the judges were in total agreement on the classification of every failure incident. The final tally of incidents, classified into each failure dimension of our classification system, is summarized in Column 2 of Table 4.

\section{Content Analysis for E-Commerce Service Failure Consequences}

Content analytical procedures for e-commerce service failure consequences are adapted from Keaveney (1995) and depicted in Appendix F. The initial classification of the entire sample of 374 accounts of negative consequences proves to be reliable with an intra-reliability score of 0.87 and an interreliability value of 0.86 . Because a one-to-one mapping between accounts of negative consequences and expectation disconfirmation constructs is a precondition for csQCA in this investigation, follow-up interviews were convened with the two judges to harmonize the placement of each failure consequence.

Content analysis of e-commerce service failure consequences did not yield any additional disconfirmed expectancy construct. Table 4 summarizes the descriptive statistics for our e-commerce service failure classification system and Appendix $G$ offers examples of the eventual classification of negative consequences in relation to each constituent failure dimension.

\section{Exploration of Theoretical Model: Chi-Square and Crisp-Set Qualitative Comparative Analysis (csQCA)}

To investigate the validity of our theoretical model, a chisquare test was performed to compare the extent to which observed negative consequences of failure incidents conform to hypothesized relationships (i.e., "goodness to fit" between observed and expected data). Table 5 summarizes statistical deviations of observed negative consequences associated with each of the three higher-order failure categories (i.e., information, functional, and system failures) from that of expectations. Positive values in Table 5 represent effects beyond that expected by chance.
We then computed the "goodness to fit" between observed and expected data. The generated chi-square value $\left(\chi^{2}=\right.$ $124.2 ; p=.0000)$ indicates that we can reject our null hypothesis of statistical independence between failure categories and negative consequences. Together with Table 5, we can deduce that information failures are associated with disconfirmed outcome expectancy, functional failures are associated with disconfirmed process expectancy, and system failures are associated with disconfirmed cost expectancy, thereby lending support to Propositions 1, 2, and 3. Yet, chi-square statistics should be interpreted with caution. Given sufficiently large data samples, it is almost certain that one can always reject null hypothesis in chi-square tests. Further, the chi-square statistic does not say much about the strength of association between failure categories and negative consequences. For this reason, we turned to csQCA as a complementary data analytical technique to triangulate deductions reached via the chi-square test. As noted by Marx (2010), csQCA contributes to theory development by comparing "similarities and differences of a limited set of comparable cases [in order to pinpoint] structural conditions which procede a relevant outcome" (p. 138).

The objective of csQCA is to detect correlations between indicators (i.e., e-commerce service failures) and outcome variables (i.e., disconfirmed expectancies). To perform csQCA, the first step is to recode the sample of e-commerce service failure incidents into binary values for different sets of indicators based on whether an incident belongs to a certain higher-order failure category (i.e., information failure, functional failure, system failure, or nontechnological failure). A value of 1 indicates that an incident is a member of a specific failure set whereas a value of 0 indicates that it is not. For instance, if an incident belongs to the category of information failure, then a value of 1 is assigned to the set of information failures and a value of 0 for all others (i.e., functional failures, system failures, and nontechnological failures). The same was done for accounts of e-commerce service failure consequences in which each account receives a binary value of 1 or 0 for different sets of outcomes variables depending on whether it belongs to disconfirmed outcome expectancy, disconfirmed process expectancy, disconfirmed cost expectancy, or no disconfirmed expectancy.

The sets of binary values were fed into the fuzzy set/Qualitative Comparative Analysis (fs/QCA) software (Ragin et al. 2006) as raw data to generate a truth table for disconfirmed outcome discrepancy as illustrated in Table 6.

Table 6 lists the number of incidents that are members of each failure set for disconfirmed outcome expectancy. Additionally, the fs/QCA software generates a set-theoretic consistency value denoting the proportion of incidents in each 
failure set that are associated with disconfirmed outcome discrepancy (Ragin et al. 2006). Values below $0.5^{9}$ indicate inconsistency and suggest that the corresponding failure set is not associated with disconfirmed outcome discrepancy. Conversely, values of 0.5 and above confirm the existence of an association between the corresponding failure set and disconfirmed outcome expectancy. Table 6 shows that 85 incidents out of the entire data sample belong to the set of information failures with a consistency value of 0.624 . This implies that $62.4 \%$ of these 85 incidents are associated with disconfirmed outcome discrepancy and it is reflected as a value of 1 in the disconfirmed outcome expectancy column for the set of information failures. All other failure sets with a consistency value above 0.5 are given identical treatment (i.e., nontechnological failure with a consistency score of 0.712). Conversely, there are 89 incidents out of the entire data sample that belong to the set of functional failures, but for this set, a consistency value of 0.292 is registered. This implies that only $29.2 \%$ of these incidents are associated with disconfirmed outcome discrepancy. A value of 0 was thus assigned for the set of functional failures as is the case for system failures with a consistency score of 0.149 .

csQCA was performed for disconfirmed outcome discrepancy based on the truth table presented in Table 6. Results are summarized in the following Boolean expression: ${ }^{10}$

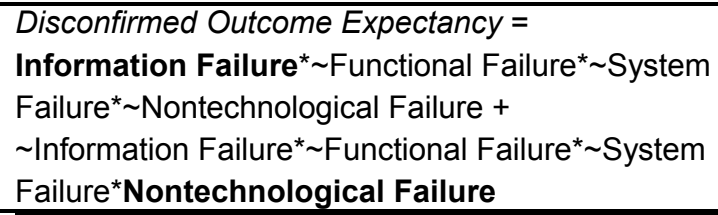

The csQCA results suggest that incidents belonging to the set of information failures and the set of nontechnological failures are associated with disconfirmed outcome expectancy. The overall consistency of the solution is 0.657 and its

\footnotetext{
${ }^{9} \mathrm{~A}$ consistency value of 0.5 and above would indicate that a majority $(\geq 50 \%)$ of failure incidents are associated with a specific negative consequence. The choice of 0.5 stems from the work of Marx and Dusa (2011) in which they discovered that a probability of 0.5 constitutes an appropriate benchmark for model specification in csQCA.

${ }^{10}$ The Boolean expression of csQCA should be interpreted as the set of indictor conditions for which an outcome variable emerges. The Boolean expression for disconfirmed outcome expectancy thus implies that disconfirmed outcome expectancy would be a likely outcome if information and nontransaction-oriented failure were to occur as specified in the expression. For example, disconfirmed outcome expectancy would emerge when inaccurate information is provided given the absence of all other forms of e-commerce service failure or when product delivery problems are present given the absence of all other forms of e-commerce service failure.
}

coverage is 0.652 . Solution coverage captures the proportion of members belonging to the outcome variable set that is associated with corresponding members belonging to the indicator sets represented in the Boolean expression. In our case, it means that $65.2 \%$ of all accounts of disconfirmed outcome expectancy are associated with incidents belonging to information and nontechnological failures. This lends support to Proposition 1.

Using the same analytical procedures, a second truth table was generated with disconfirmed process expectancy as the outcome variable (see Table 7).

Performing csQCA for disconfirmed process expectancy yielded the following Boolean expression:

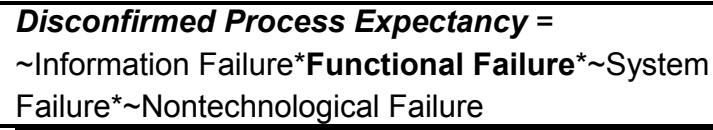

The csQCA results reveal that incidents belonging to the set of functional failures are associated with disconfirmed process expectancy with an overall consistency of 0.573 and a solution coverage of 0.383 , thereby lending support to Proposition 2.

For disconfirmed cost expectancy, its generated truth table indicates it is not associated with any of the higher-order failure categories (see Table 8). Proposition 3 is not supported.

The same observation is made for the outcome variable of no disconfirmed expectancy (see Table 9).

Table 10 summarizes the results of our testing of the theoretical model via chi-square test and csQCA.

\section{Post Hoc Analysis}

Post hoc analysis was undertaken to assess the association of constituent dimensions of information, functional and system failures with the outcome variables of disconfirmed outcome, process, and cost expectancies. We hope to glean insights into the effects of constituent failure dimensions and possibly explaining why, contrary to results from the chi-square test, system failures were not found to be associated with disconfirmed cost expectancy for csQCA (see Table 10). While truth tables were generated for each of the outcome variables separately, consistency values were consolidated in Table 11 to give an overarching view of the associations between constituent failure dimensions and disconfirmed expectancies. 


Table 7. fs/QCA Truth Table on Disconfirmed Process Expectancy
\begin{tabular}{|c|c|c|c|c|c|c|}
$\begin{array}{c}\text { Information } \\
\text { Failure }\end{array}$ & $\begin{array}{c}\text { Functional } \\
\text { Failure }\end{array}$ & $\begin{array}{c}\text { System } \\
\text { Failure }\end{array}$ & $\begin{array}{c}\text { Nontechnological } \\
\text { Failure }\end{array}$ & $\begin{array}{c}\text { Number of } \\
\text { Incidents }\end{array}$ & $\begin{array}{c}\text { Disconfirmed } \\
\text { Process }\end{array}$ & Consistency \\
\hline 1 & 0 & 0 & 0 & 85 & 0 & 0.165 \\
\hline 0 & 1 & 0 & 0 & 89 & 1 & 0.573 \\
\hline 0 & 0 & 1 & 0 & 148 & 0 & 0.419 \\
\hline 0 & 0 & 0 & 1 & 52 & 0 & 0.115 \\
\hline
\end{tabular}

\section{Table 8. fs/QCA Truth Table on Disconfirmed Cost Expectancy}

\begin{tabular}{|c|c|c|c|c|c|c|}
\hline $\begin{array}{c}\text { Information } \\
\text { Failure }\end{array}$ & $\begin{array}{c}\text { Functional } \\
\text { Failure }\end{array}$ & $\begin{array}{c}\text { System } \\
\text { Failure }\end{array}$ & $\begin{array}{c}\text { Nontechnological } \\
\text { Failure }\end{array}$ & $\begin{array}{c}\text { Number of } \\
\text { Incidents }\end{array}$ & $\begin{array}{c}\text { Disconfirmed } \\
\text { Cost }\end{array}$ & Consistency \\
\hline 1 & 0 & 0 & 0 & 85 & 0 & 0.212 \\
\hline 0 & 1 & 0 & 0 & 89 & 0 & 0.056 \\
\hline 0 & 0 & 1 & 0 & 148 & 0 & 0.385 \\
\hline 0 & 0 & 0 & 1 & 52 & 0 & 0.077 \\
\hline
\end{tabular}

\section{Table 9. fs/QCA Truth Table on No Disconfirmed Expectancy}

\begin{tabular}{|c|c|c|c|c|c|c|}
\hline $\begin{array}{l}\text { Information } \\
\text { Failure }\end{array}$ & $\begin{array}{c}\text { Functional } \\
\text { Failure }\end{array}$ & $\begin{array}{l}\text { System } \\
\text { Failure }\end{array}$ & $\begin{array}{c}\text { Nontechnological } \\
\text { Failure }\end{array}$ & $\begin{array}{l}\text { Number of } \\
\text { Incidents }\end{array}$ & $\begin{array}{l}\text { No Disconfirmed } \\
\text { Expectancy }\end{array}$ & Consistency \\
\hline 1 & 0 & 0 & 0 & 85 & 0 & 0.000 \\
\hline 0 & 1 & 0 & 0 & 89 & 0 & 0.079 \\
\hline 0 & 0 & 1 & 0 & 148 & 0 & 0.047 \\
\hline 0 & 0 & 0 & 1 & 52 & 0 & 0.096 \\
\hline
\end{tabular}

\section{Table 10. Summary of Theoretical Model Testing}

\section{Proposition}

P1: While information failures within an e-commerce website will positively influence consumers' disconfirmed outcome, process, and cost expectancies, the effect will be stronger for disconfirmed outcome expectancy.

P2: While functional failures within an e-commerce website will positively influence consumers' disconfirmed outcome, process, and cost expectancies, the effect will be stronger for disconfirmed process expectancy.

P3: While system failures within an e-commerce website will positively influence consumers' disconfirmed outcome, process, and cost expectancies, the effect will be stronger for disconfirmed cost expectancy.

\begin{tabular}{|c|c|}
\hline \multicolumn{2}{|c|}{ Outcome } \\
\hline $\mathbf{X}^{2}$ Test & csQCA \\
Supported & Supported \\
Supported & Supported \\
Supported & $\begin{array}{c}\text { Not } \\
\text { supported }\end{array}$ \\
\hline
\end{tabular}


Table 11. Summary of Consistency Values between Failure Dimensions and Disconfirmed Expectancies (Sample $N=374$ )

\begin{tabular}{|c|c|c|c|c|}
\hline Failure Dimension & $\begin{array}{c}\text { Disconfirmed } \\
\text { Outcome } \\
\text { Expectancy }\end{array}$ & $\begin{array}{c}\text { Disconfirmed } \\
\text { Process } \\
\text { Expectancy }\end{array}$ & $\begin{array}{l}\text { Disconfirmed } \\
\text { Cost Expectancy }\end{array}$ & $\begin{array}{c}\text { No } \\
\text { Disconfirmed } \\
\text { Expectancy }\end{array}$ \\
\hline Information Failure & $0.624^{*}$ & 0.165 & 0.212 & 0.000 \\
\hline Inaccurate Information & $0.714^{*}$ & 0.143 & 0.143 & 0.000 \\
\hline Incomplete Information & $0.619^{*}$ & 0.238 & 0.143 & 0.000 \\
\hline Irrelevant Information & 0.273 & 0.091 & $0.636^{*}$ & 0.000 \\
\hline Untimely Information & $0.680^{*}$ & 0.160 & 0.160 & 0.000 \\
\hline Functional Failures & 0.292 & $0.573^{*}$ & 0.056 & 0.079 \\
\hline Needs Recognition Failure & 0.000 & $1.000^{*}$ & 0.000 & 0.000 \\
\hline Alternatives Identification Failure & 0.250 & $0.500^{*}$ & 0.250 & 0.000 \\
\hline Alternatives Evaluation Failure & 0.000 & $1.000^{*}$ & 0.000 & 0.000 \\
\hline Acquisition Failure & 0.164 & $0.709^{*}$ & 0.036 & 0.091 \\
\hline Post-Purchase Failure & $0.682^{*}$ & 0.182 & 0.045 & 0.091 \\
\hline System Failures & 0.149 & 0.419 & 0.385 & 0.047 \\
\hline Inaccessibility & 0.101 & $0.667^{*}$ & 0.174 & 0.058 \\
\hline Non-Adaptability & 0.059 & $0.588^{*}$ & 0.294 & 0.059 \\
\hline Non-Navigability & 0.208 & 0.125 & $0.625^{*}$ & 0.042 \\
\hline Delay & 0.097 & 0.065 & $0.806^{*}$ & 0.032 \\
\hline Insecurity & $0.857^{*}$ & 0.143 & 0.000 & 0.000 \\
\hline Nontechnological Failures & $0.712^{*}$ & 0.115 & 0.077 & 0.096 \\
\hline Mischarging & $0.615^{*}$ & 0.154 & 0.077 & 0.154 \\
\hline Product Delivery Problems & $0.750^{*}$ & 0.107 & 0.036 & 0.107 \\
\hline $\begin{array}{l}\text { Unresponsive to Customer } \\
\text { Enquiries }\end{array}$ & $0.727^{*}$ & 0.091 & 0.182 & 0.000 \\
\hline
\end{tabular}

* Boolean solution found between failure dimension and corresponding disconfirmed expectancy construct based on csQCA.

Several deductions may be drawn from Table 11 with regard to the association of constituent failure dimensions with disconfirmed expectancies. First, with the exception of irrelevant information that is associated with disconfirmed cost expectancy, the remaining types of information failure (i.e., inaccurate information, incomplete information, and untimely information) are associated with disconfirmed outcome expectancy as postulated. A plausible reason could be that irrelevant information, once detected, is disregarded or discounted by consumers and did not factor into their transactional decisions. Consequently, other than translating into a waste of time on the part of consumers, irrelevant information does not affect either the outcome or the process of e-commerce transactions. Second, most forms of functional failure (i.e., needs recognition failure, alternatives identification failure, alternatives evaluation failure, and acquisition failures) are associated with disconfirmed process expectancy as postulated; the sole exception being post-purchase failure, which is associated with disconfirmed outcome expectancy. A possibility could be that post-purchase functionalities deal more with after-sales service rather than the process of acquiring products and/or services. Conceivably, the absence of post-purchase functionalities would impact consumers' outcome expectations. Third, the association of system failures with disconfirmed expectancies are much more diffused, which might explain why a statistically significant effect was not observed at the aggregate level. Whereas non-navigability and delay are associated with disconfirmed cost expectancy as postulated, inaccessibility and non-adaptability are associated with disconfirmed process expectancy. Because inaccessibility inhibits consumers' ability to gain access to e-commerce services that may be necessary for the transactional process to continue, it could lead to the disconfirmation of their process expectancy. Conversely, adaptability emphasizes the customization of e-commerce service content to match consumers' transactional needs. For 
this reason, non-adaptability would lead to inflexibility in the delivery of service content, which might disrupt the transactional process. Insecurity on the other hand, is associated with disconfirmed outcome expectancy. An explanation for this contradiction may be that insecurity, in the context of e-commerce transactions, basically implies that unauthorized individuals are able to tap into the transactional process and access confidential personal information (e.g., name, address and credit card information) for fraudulent activities. Consequently, consumers' outcome expectancy may be disconfirmed. Finally, all three nontechnological failure dimensions are associated with disconfirmed outcome expectancy.

\section{Discussion}

Although research into system success has had a long history (see DeLone and McLean 1992, 2003) with extensive debates persisting in the realm of online transactional environments (see Xu et al. 2013), there are comparatively fewer studies that delve into e-commerce service failures. Yet, as revealed in our review of extant literature on service failures (see Appendix A), there are signs to indicate that the phenomenon of e-commerce service failures deserve their own research agenda. This paper takes a small but concrete step toward developing this research agenda by constructing and validating a theoretical model of e-commerce service failures and their consequences. Detailed implications for theory and practice are elaborated below.

\section{Implications for Theory}

This paper contributes to contemporary knowledge about e-service and system success in three ways. First, despite a long tradition of research into the determinants of system success, there have been limited scholarly attempts to investigate e-commerce service failures as an equally salient phenomenon for online transactions (Holloway and Beatty 2003). Nonetheless, our review of extant literature points to an urgency to recognize e-commerce service failures as a separate research stream with its own distinctive cause-andeffect relationships. Even marketing scholars like Holloway and Beatty, who pioneered one of the first studies on e-commerce service failures, have largely ignored the knowledge accumulated in the areas of e-services and system success by placing emphasis on the service deficiencies of such failures while neglecting their technological defects. This study thus situates e-commerce service failures squarely within information systems literature by drawing parallels with the well-established research streams of e-service and system success to identify areas of service where potential problems might emerge during online transactions.
Second, we synthesized the e-service and system success literatures to derive a dual-layer classification system of e-commerce service failures that caters exclusively to e-commerce transactional environments. Through the deductive derivation of generic failure categories salient to e-commerce websites (i.e., information failure, functional failure, and system failure), our classification system is the first to offer theoretically grounded explanations for distinct sources of e-commerce service failures. Moreover, under each of these higher-order failure categories, we identified lower-order constituent dimensions that accentuate design flaws which are within the e-merchant's ability to correct. Our classification system thus expands on the published work of Cenfetelli et al. (2008) and Xu et al. (2013) on e-commerce service quality. Whereas Xu et al. attested to the criticality of information and system attributes for online transactions, Cenfetelli et al. countered that supporting service functionalities constitute equally prominent determinants of e-commerce service quality. The parsimony and representativeness of our classification system was corroborated through descriptive accounts of actual e-commerce service failure incidents, which were elicited via a qualitative field survey. The theoretical significance of a dual-layer classification system for e-commerce service failures is especially evident from our post hoc analysis where different consequences were observed for lower-order constituent dimensions belonging to the same higher-order failure category (see Table 11). Furthermore, the discovery of nontechnological failures as a salient failure category implies that consumers are not only deterred by technological impediments during online transactions, they also tend to equate inferior after-sales business practices (i.e., mischarging, product delivery problems, and unresponsive to customer enquiries) with e-commerce service failures. In a way, this study enriches extant literature on e-service and system success by drawing attention to the complimentary role of business practices in fostering a rewarding customer service experience during online transactions that goes beyond the technological performance of e-commerce websites.

Finally, we advanced a theoretical model with propositions that explain and predict consequences of e-commerce service failures from the consumer's perspective. To the best of our knowledge, there is no study to-date that explores consequences of e-commerce service failures in detail (see Appendix A). Specifically, we distinguished among consumers' expectations with regard to transactional outcome, process, and cost, and posit that each category of e-commerce service failure is associated predominantly with a particular type of expectation. Evidence proved that our postulations are generally on target. With the exceptions of "irrelevant information" and "post-purchase failure," it can be noted that most forms of information failure tend to disconfirm con- 
sumers' outcome expectancies whereas the majority of functional failures tend to disconfirm consumers' process expectancies. Although system failures, as a whole, appear not to have any impact on consumers' expectations, it could be the case that different forms of system failure may lead to different consequences as demonstrated through our post hoc analysis (see Table 11). Empirical evidence from this study thus suggests that contrary to past studies on system success, it may be presumptuous to treat constituent dimensions belonging to the same higher-order category (i.e., information, functional, and system attributes) as having an identical influence on consumer behavior (see $\mathrm{Xu}$ et al. 2013), a probable avenue for further research.

\section{Implications for Practice}

This paper should be of interest to e-merchants for three reasons. First, our e-commerce service failure classification system can serve as an analytical toolkit for e-merchants to conduct benchmark studies on their e-commerce websites to assess whether visitors to the websites face difficulties during online transactions. Because the validity of the failure categories and dimensions in our classification system was ascertained through critical incidents of e-commerce service failures, the majority of which $(>80 \%)$ had transpired within the last 6 months from the end-date of our data collection effort (see Table 3), it seems that faulty e-commerce websites are more prevalent than what e-merchants could have imagined. This may also account for the $45 \%$ rate of failure in e-commerce transactions that is reported by Oneupweb (2010).

Second, our e-commerce service failure classification system offers actionable design prescriptions for e-merchants to improve the quality of their e-commerce websites. Even though the failure dimensions do not delve into the technicalities of e-service design, they do offer guidelines on the areas to watch out for during the maintenance of e-commerce websites. Because the design of e-commerce websites is constantly evolving to cater to changing customer preferences (Wind 2001), our classification system should come in handy as a checklist to pinpoint design flaws (if any) that may deter consumers from visiting. The merit of taking preemptive measures against potential sources of service failures has been stressed by Cranage and Sujan (2004), who noted that customer loyalty is highest whenever failures are rendered foreseeable and transparent to consumers.

Finally, by delineating consequences into disconfirmed outcome, process, and cost expectancies, we provide clarity to the consequences of various forms of e-commerce service failures. This information could prove useful to e-merchants by allowing them to channel resources to improve high priority e-commerce services. For instance, it can be inferred from the post hoc analysis that the transactional process can be compromised when an e-commerce website is missing functionalities, which cater to needs recognition, alternatives identification, alternatives evaluation, and/or acquisition activities. Conversely, the negative impact of irrelevant information may not be pronounced from the consumer's standpoint because it does not affect the transactional process and outcome in a detrimental way. Since Nielsen Norman Group (2001) documented that $44 \%$ of consumers are dissuaded from making purchases due to problems encountered in transactional activities associated with product or service acquisition, it may be wise for e-merchants to channel their technological investments toward securing the delivery of functionalities that enable the preceding activities.

\section{Limitations}

Given the exploratory nature of our research objectives, caveats exist with regard to this study. First, although we subscribe to the conceptual approach espoused by Bailey (1994), we are aware that our classification system is neither definitive nor exhaustive of the range of possible service failure occurrences. What we have accomplished in this study is to take the first step toward the derivation of a dual-layer classification system of e-commerce service failures containing conceptually distinct failure categories and dimensions. Future research can expand on our work by validating and refining our classification system through replication studies.

Second, while CIT is suitable for eliciting practical instances of events that have transpired, the retrospective nature of the recollection implies that events may not be remembered accurately and there is no way of verifying whether memory distortion has taken place. However, there is an inherent advantage in employing CIT for data collection on e-commerce service failures; failure events are more likely to leave a lasting impression on respondents due to heightened emotions (Andreassen 2001; McColl-Kennedy and Sparks 2003; Smith et al. 1999). Also, due to the retrospective nature of the data collection process, it is unrealistic to invite respondents to recall their expectations prior to a reported failure incident because these expectations would most likely be shaped by failure consequences in hindsight. Instead, in presenting respondents with our working definition of e-commerce service failures, they were prompted to recollect failure incidents for which minimum standards of service performance have been breached — what Bitner et al. (1990) stressed as "fundamentally necessary factors leading to customers' dissatisfactory evaluations" (p. 73). Still, we do 
not dispute that fresh insights may be gleaned from controlling for consumers' expectations prior to occurrences of e-commerce service failures, an endeavor best accomplished through future research employing causal methods (e.g., experiments).

Third, certain dimensions in our e-commerce service failure classification system are not well represented in the data sample (see Table 4), which in turn casts doubt on the generalizability of our empirical findings. Because the empirical study was based on the elicitation of actual e-commerce service failure incidents, we were unable to control for the type of failure experienced by each respondent in reality. While we cannot rule out the possibility that subsequent studies may invalidate associations between less-represented failure dimensions and disconfirmed expectancies as uncovered in our post hoc analysis (see Table 11), the substantive size of failure incidents identified in each of the three higher-order failure categories (i.e., information failure, functional failure, and system failure) increases the confidence in that the analytical results pertaining to our main propositions should hold.

Fourth, although we have taken steps to restrict respondents' recollection of failure incidents to technological flaws with e-commerce websites, there were still instances where respondents recalled failures that are not technological problems (see Table 4). While we admit that errors related to business practices (i.e., mischarging), purchase delivery (i.e., product delivery problems), and customer enquiries (i.e., unresponsive to customer enquiries) are also part and parcel of e-commerce transactions, such failures tend to be nontechnological in nature and could not be rectified through improvements to web interface design. Still, we report analytical findings for these nontechnological failures because they draw attention to the complimentary role of business practices in online transactions, an area for future research.

Fifth, while we have taken every effort to ensure that all data points (i.e., e-commerce service failure incidents and consequences) are self-contained and content analytical procedures are rigorous, the interpretive nature of our research may impose a certain degree of subjectivity to our findings. Moreover, due to the requirements of the chi-square test and the fs/QCA software, we were forced to take binary positions (i.e., either 1 or 0 ) for every data point, even though it might have multiple outcomes with varying intensities. Our empirical findings should thus be interpreted as a conservative assessment of the impact of e-commerce service failures on consumers' disconfirmed expectancies. One is likely to witness amplifications in the intensity of these relationships when the data analysis technique allows for multiple correlations to exist between indicators and outcome variables (e.g., structural equation models).
Finally, the absence of direct interaction with human service providers for e-commerce websites implies that it is much harder to separate web-enabled services from information and technical aspects of online transactions (Xu et al. 2013). Such concerns are equally valid for this study. Because interdependencies exist among information, functional and system aspects of e-commerce transactions (Xu et al. 2013), it could be the case that a reported incident of e-commerce service failure is caused by an earlier technological problem, which goes undetected by the respondent. During data collection, we have strived to minimize this possibility by adapting data collection strategies from CIT. Through respondents' descriptive accounts about what transpired before, during, and after the occurrence of an e-commerce service failure, we were able to carefully scrutinize each incident to affirm that the source of failure has been correctly isolated. Although CIT is ideal for isolating the primary cause of an e-commerce service failure incident due to its strength in eliciting descriptive accounts of actual events that transpired (Viney 1983), it is unsuitable for capturing perceptually driven spillover effects from e-commerce service failures (see Harris Interactive 2006). To accomplish our research objectives, we hence traded off the ability to draw inferences about the spillover effects of e-commerce service failures for the richness of data that could be solicited for a single failure incident. Nonetheless, we acknowledge the importance of ascertaining whether spillover effects exist for e-commerce service failures and call for further research in this direction.

\section{Future Research Avenues}

Our study lays the groundwork for opening up an entirely new line of research into e-commerce services. Subsequent empirical investigations should be undertaken to further refine and validate our theoretical model through alternate methods and for other forms of online transactions. For example, experiments can be designed to verify the causality of associations between e-commerce service failures and consumers' perceptions of disconfirmed expectancies exposed in our empirical study. Also, future research can replicate our empirical study across other forms of online transactions (e.g., electronic marketplaces) to test, adapt, and generalize our e-commerce service failure classification system to the broader domain of e-services.

While we have gathered a relatively representative sample of e-commerce service failures, it is cross-sectional in nature. There is still much to be explored about the frequency and longitudinal effects of e-commerce service failures on online consumer behaviors. Previous studies of offline service failures show that consumers react much more unfavorably toward failure events that have a higher rate of recurrence 
(e.g., Bitner 1990; Leong et al. 1997; Maxham and Netemeyer 2002). Future research can investigate whether consumers react differently to the (1) frequency with which a particular form of e-commerce service failure recurs and (2) time duration between two consecutive recurrences of the same failure. Attribution theory claims that individuals are rational information processors whose behaviors are directed by their causal inferences (Folkes 1984). Whenever an e-commerce service failure occurs, it is likely to trigger a cognitive attribution process that involves an assessment of the losses incurred (Bearden and Teel 1983) and an attribution of blame for the ensuing problem (Bitner 1990; McColl-Kennedy and Sparks 2003). Because past studies have revealed a strong correlation between consumers' causal attributions of service failures and their evaluations of service encounters (Hess et al. 2007), it is worth investigating whether different forms of e-commerce service failures in our classification system result in different types of causal attribution and the impact of such attributions on online consumer behaviors.

Whenever service failures occur, consumers expect service providers to be competent and caring in offering appropriate recovery measures (Bitner et al., 1990). Smith et al. (1999) demonstrated that it is possible to recover from almost any kind of service failure, regardless of its type and magnitude, so long as the recovery measure is commensurate with the failure. While service failures may be unwelcome occurrences, the effectiveness of corresponding service recovery measures determines whether consumers would be appeased and retained (Smith et al. 1999). Yet, as admitted by Holloway and Beatty, existing e-commerce websites are not only lagging in the provision of e-service recovery technologies to alleviate e-commerce service failures when they occur, but even when such technologies are available, recovery measures are usually incommensurate with the damages suffered by consumers. An avenue for future research lies in determining the types of e-service recovery technology that would allow consumers to recover from each form of e-commerce service failure in our classification system.

\section{Conclusion}

Despite the infancy of research on e-commerce service failure, both academics and practitioners have appealed for studies that can shed light on its causes and consequences. Responding to the call, we synthesized e-service and system success research streams to construct a classification system of e-commerce service failures that categorizes causes of failure according to whether they stem from the information, functional, or system aspects of e-commerce websites. Drawing on EDT, we further proposed that e-commerce service failure consequences are rooted in the disconfirmation of consumers' outcome, process, and/or cost expectancies. Data gathered via a qualitative field survey not only attests to the robustness of our classification system, but it aids in the validation of a theoretical model of e-commerce service failure classifications and their consequences, which can be refined through future investigations.

\section{Acknowledgments}

We thank the senior editor, Ron Thompson, the associate editor J. J. Po-An Hsieh, and the two anonymous reviewers for their insightful comments and suggestions that have been invaluable in helping us to improve the manuscript. We are especially grateful to the senior editor and the associate editor for their developmental approach in guiding the manuscript through the review process. The authors are also grateful for financial support from the Social Sciences and Humanities Research Council of Canada (SSHRC) in conducting this study.

\section{References}

Agarwal, R., and Venkatesh, V. 2002. “Assessing a Firm's Web Presence: A Heuristic Evaluation Procedure for Measurement of Usability," Information Systems Research (13:20), pp. 168-186.

Andreassen, T. W. 2001. "From Disgust to Delight: Do Customers Hold a Grudge?," Journal of Service Research (4:1), pp. 39-49.

Bailey, K. D. 1994. Typologies and Taxonomies: An Introduction to Classification Techniques, Thousand Oaks, CA: Sage Publications.

Barber, R. E., and Lucas, H. C. 1983. "System Response Time, Operator Productivity, and Job Satisfaction," Communication of the ACM (26:11), pp. 972-986.

Barnes, S. J., and Vidgen, R. 2001. "An Evaluation of CyberBookshops: The WebQual Method," International Journal of Electronic Commerce (6:1), pp. 11-30.

Bauer, R. A. 1960. "Consumer Behavior as Risk Taking," in Dynamic Marketing for a Changing World, R. Hancock (ed.), Chicago: American Marketing Association, pp. 389-398.

Bearden, W. O., and Teel, J. E. 1983. "Some Determinants of Consumer Satisfaction and Complaint Report," Journal of Marketing Research (20:1), pp. 21-28.

Benlian, A., Koufaris, M., and Hess, T. 2011. "Service Quality in Software-as-a-Service: Developing the SaaS-Qual Measure and Examining its Role in Usage Continuance," Journal of Management Information Systems (28:3), pp. 85-126.

Berry, L. L., Zeithaml, V. A., and Parasuraman, A. 1985. "Quality Comes in Services," Business Horizon (28:1), pp. 44-52.

Bhattacherjee, A. 2001. "Understanding Information Systems Continuance: An Expectation-Confirmation Model," MIS Quarterly (25:3), pp. 351-370.

Bhattacherjee, A. and Premkumar, G. 2004. "Understanding Changes in Belief and Attitude Toward Information Technology Usage: A Theoretical Model and an Empirical Test," MIS Quarterly (28:2), pp. 229-255. 
Bitner, M. J. 1990. "Evaluating Service Encounters: The Effects of Physical Surroundings and Employee Responses," Journal of Marketing (54:1), pp. 69-82.

Bitner, M. J. 2001. "Service and Technology: Opportunities and Paradoxes," Managing Service Quality (11:6), pp. 375-379.

Bitner, M. J., Booms, B. H., and Mohr, L. A. 1994. "Critical Service Encounters: The Employee's Viewpoint," Journal of Marketing (58:1), pp. 95-106.

Bitner, M. J., Booms, B. H., and Tetreault, M. S. 1990. "The Service Encounter: Diagnosing Favorable and Unfavorable Incidents," Journal of Marketing (54:1), pp. 71-84.

Bitner, M. J., Brown, S. W., and Meuter, M. L. 2000. “Technology Infusion in Service Encounters," Journal of the Academy of Marketing Science (28:1), pp. 138-149.

Boyatzis, R. E. 1998. Transforming Qualitative Information: Thematic Analysis and Code Development, Thousand Oaks, CA: Sage Publications.

Boyer, K. K., Hallowell, R., and Roth, A. V. 2002. "E-Services: Operating Strategy: A Case Study and a Method for Analyzing Operational Benefits," Journal of Operations Management (20:2), pp.175-188.

Butterfield, L. D., Borgen, W. A., Amundson, N. E., and Maglio, A. S. T. 2005. "Fifty Years of the Critical Incident Technique: 1954-2004 and Beyond," Qualitative Research (5:4), pp. 475-497.

Carugati, A., Hadzilias, E., and Demoulin, N. 2005. "Setting the Framework for Developing E-Government Services on Cultural Heritage," in Proceedings of the $13^{\text {th }}$ European Conference on Information Systems, D. Bartmann (ed.), Resensburg, Germany, paper 132.

Cenfetelli, R. T. 2004. "Inhibitors and Enablers as Dual Factor Concepts in Technology Usage," Journal of the Association for Information Systems (5:11), pp. 472-492.

Cenfetelli, R. T., Benbasat, I., and Al-Natour, S. 2008. "Addressing the What and How of Online Services: Positioning SupportingServices Functionality and Service Quality for Business to Consumer Success," Information Systems Research (19:2), pp. 161-181.

Cenfetelli, R. T., and Schwarz, A. 2011. "Identifying and Testing the Inhibitors of Technology Usage Intentions," Information Systems Research (22:4), pp. 808-823.

Childers, T. L., Carr, C. L., Peck, J., and Carson, S. 2001. "Hedonic and Utilitarian Motivations for Online Retail Shopping Behavior," Journal of Retailing (77:4), pp. 511-535.

Chiu, C-M., Chiu, C-S., and Chang, H-C. 2007. "Examining the Integrated Influence of Fairness and Quality on Learners' Satisfaction and Web-Based Learning Continuance Intention," Information Systems Journal (17:3), pp. 271-287.

Cohen, J. 1968. "Weighted Kappa: Nominal Scale Agreement Provision for Scaled Disagreement or Partial Credit," Psychological Bulletin (70:4), pp. 213-220.

Colgate, K., and Norris, M. 2001. "Developing a Comprehensive Picture of Service Failure," International Journal of Service Industry Management, (12:3), pp. 215-33.

Collier, J. E., and Bienstock, C. C. 2003. "A Conceptual Framework for Measuring E-Service Quality," in Developments in
Marketing Science, Academy of Marketing Science Conference Proceedings, H. Spotts, (ed.), Academy of Marketing Science, Corel Gables, FL, pp. 158-162.

Collier, J. E., and Bienstock, C. C. 2006. "Measuring Service Quality in E-Retailing," Journal of Service Research (8:3), pp. 260-275.

Connolly, R., Bannister, F., and Kearney, A. 2010. “Government Website Service Quality: A Study of the Irish Revenue Online Service," European Journal of Information Systems (19:4), pp. 649-667.

Cox, D. F. 1967. Risk Taking and Information Handling in Consumer Behavior, Cambridge, MA: Harvard University Press.

Cox, D. F. and Rich. S. U. 1964. "Perceived Risk and Consumer Decision Making: The Case of Telephone Shopping," Journal of Marketing Research (1:1), pp. 2-39.

Cranage, D., and Sujan, H. 2009. "Customer Choice: A Preemptive Strategy to Buffer the Effects of Service Failure and Improve Customer Loyalty," Journal of Hospitality \& Tourism Research (28:1), pp. 3-20.

Crespo, A. H., del Bosque, I. R., and de los Salmones, M. M. G. 2009. "The Influence of Perceived Risk on Internet Shopping Behavior: A Multidimensional Perspective," Journal of Risk Research (12:2), pp. 259-277.

Dabholkar, P. A. 1996. "Consumer Evaluations of New Technology-Based Self-Service Options: An Investigation of Alternative Models Of Service Quality," International Journal of Research in Marketing (13:1), pp. 29-51.

Dabholkar, P. A., Shepherd, C. D., and Thorpe, D. I. 2000. "A Comprehensive Framework for Service Quality: An Investigation of Critical Conceptual and Measurement Issues through a Longitudinal Study," Journal of Retailing (76:2), pp. 139-173.

Davis, F. D., Bagozzi, R. P., and Warshaw, P. R. 1992. "Extrinsic and Intrinsic Motivation to Use Computers in the Workplace," Journal of Applied Social Psychology (22:14), pp. 1111-1132.

Dellaert, B., and Kahn, B. E. 1999. "How Tolerable is Delay? Consumers' Evaluations of Internet Web Sites After Waiting," Journal of Interactive Marketing (13:1), pp. 41-54.

DeLone, W. H., and McLean, E. R. 1992. "Information Systems Success: The Quest for the Dependent Variable," Information Systems Research (3:1), pp. 60-95.

DeLone, W. H., and McLean, E. R. 2003. "The DeLone and McLean Model of Information Systems Success: A Ten-Year Update," Journal of Management Information Systems (19:4), pp. 9-30.

DeLone, W. H., and McLean, E. R. 2004. "Measuring E-Commerce Success: Applying the DeLone \& McLean Information Systems Success Model," International Journal of Electronic Commerce (9:1), pp. 31-47.

Devaraj, S., Fan, M. and Kohli, R. 2002. "Antecedents of B2C Channel Satisfaction and Preference: Validating E-Commerce Metrics," Information Systems Research (13:3), pp. 316-333.

DeWitt, T., and Brady, M. K. 2003. "Rethinking Service Recovery Strategies," Journal of Service Research (6:2), pp. 193-207.

Doherty, W. and Kelisky, R. 1979. "Managing VM/CMS Systems for User Effectiveness," IBM Systems Journal (18:1), pp. 143-163. 
Douglas, A., Muir, L., and Meehan, K. 2003. "E-Quality in the E-Services Provision of Legal Practices," Management Service Quality (13:6), pp. 483-491.

Etezadi-Amoli, J., and Farhoomand, A. F. 1996. "A Structural Model of End User Computing Satisfaction and User Performance," Information and Management (30:1), pp. 65-73.

Evanschitzky, H., Iyer, G. R., Hesse, J., and Ahlert, D. 2004. "E-Satisfaction: A Re-Examination," Journal of Retailing (80), pp. 239-247.

Fassnacht, M., and Koese, I. 2006. "Quality of Electronic Services: Conceptualizing and Testing a Hierarchical Model," Journal of Service Research (9:1), pp. 19-37.

Featherman, M. S., and Pavlou, P. A. 2003. "Predicting E-Services Adoption: A Perceived Risk Facets Perspective," International Journal of Human-Computer Studies (59:4), pp 451-474.

Flanagan, J. C. 1954. "The Critical Incident Technique," Psychological Bulletin (51), pp. 327-58.

Folkes, V. S. 1984. "Consumer Reactions to Product Failure: An Attributional Approach," Journal of Consumer Research (10:4), pp. 398-409.

Forrester Consulting. 2009. eCommerce Web Site Performance Today: An Updated Look At Consumer Reaction to a Poor Online Shopping Experience, Forrester Research, Inc, Cambridge, MA.

Gefen, D. 2002. "Customer Loyalty in e-Commerce," Journal of the Association for Information Systems (3:1), pp. 27-51.

Gershoff, A. D., Broniarczyk, S. M., and West, P. M. 2001. "Recommendation or Evaluation? Task Sensitivity in Information Source Selection," Journal of Consumer Research (28:3), pp. 418-438.

Gino, F., and Pisano, G. P. 2011. "Why Leaders Don't Learn From Success," Harvard Business Review (89:4), pp. 68-74.

Glover, S., and Benbasat, I. 2010. "A Comprehensive Model of Perceived Risk of E-Commerce Transactions," International Journal of Electronic Commerce (15:2), pp. 47-78.

Gounaris, S., and Dimitriadis S. 2003. "Assessing Service Quality on the Web: Evidence from Business-to-Consumer Portals," Journal of Services Marketing (17:5), pp. 529-548.

Grönroos, C., Helnomen, F., Isoniemi, K., and Lindholm, M. 2000. "The NetOffer Model: A Case Example from the Virtual Marketplace," Management Decision (38:4), pp. 243-252.

Gummerus, J., Liljander, V., Pura, M., and van Riel, A. 2004. "Customer Loyalty to Content-Based Websites: The Case of an Online Health-Care Service," Journal of Service Marketing (18:3), pp. 175-186.

Harris Interactive. 2006. "New Survey Reveals Online Transaction Issues Have Negative Impact on Customers and Businesses," TeaLeaf (available online at http://www.tealeaf.com/news/newsreleases/2006/0925.php; accessed January 27, 2011).

Haubl, G., and Trifts, V. 2000. "Consumer Decision Making in Online Shopping Environments: The Effects of Interactive Decision Aids," Marketing Science (19:1), pp. 4-21.

Hess Jr., R. L., Ganesan, S., and Klein, N. M. 2007. "Interactional Service Failures in a Pseudorelationship: The Role of Organizational Attributions," Journal of Retailing (83:1), pp. 79-95.
Hoffman, K. D., Kelley, S. W., and Rotalsky, H. M. 1995. "Tracking Service Failures and Employee Recovery Efforts," Journal of Services Marketing (9:2), pp. 49-61.

Holloway, B. B., and Beatty, S. E. 2003. "Service Failure in Online Retailing: A Recovery Opportunity," Journal of Service Research (6:1), pp. 92-105.

Homburg, C., Hoyer, W. D., and Fassnacht, M. 2002. "Service Orientation of a Retailer's Business Strategy: Dimensions, Antecedents, and Performance Outcomes," Journal of Marketing (66:4), pp. 86-101.

Igbaria, M. S., Parasuraman, J., and Baroudi, J. 1996. "A Motivational Model of Microcomputer Usage," Journal of Management Information Systems (13:1), pp.127-143.

Interactive Media Retail Group. 2012. "IMRG Multichannel E-Commerce Report 2012: E-Commerce Trends and Tips" (available online at http://go.channeladvisor.com/ IMRGeBookBanner_LP.html; accessed September 7, 2013).

Ives, B., and Learmonth, G. 1984. "The Information System as a Competitive Weapon," Communications of the ACM(27:12), pp. 1193-1201.

Ives, B., and Mason, R. O. 1990. "Can Information Technology Revitalize Your Customer Service?," Academy of Management Executive (4:4), pp. 52-69.

Ives, B., Olson, M., and Baroudi, J. J. 1983. "The Measurement of User Information Satisfaction," Communications of the ACM, pp. 785-793.

Jacoby, J. 1998. “Consumer Behavior: A Quadrennium,” Annual Review of Psychology (49:1), pp. 319-344.

Janda, S., Trocchia, P. J., and Gwinner, K. P. 2002. "Consumer Perceptions of Internet Retail Service Quality," International Journal of Service Industry Management (13:5), pp. 412-431.

Jedetski, J., Adelman, L., and Yeo, C. 2002. "How Web Site Decision Technology Affects Consumers," IEEE Internet Computing (6:2), pp. 72-79.

Jiang, J. J., Klein, G., and Carr, C. L. 2002. "Measuring Information System Service Quality: SERVQUAL from the Other Side," MIS Quarterly (26:2), pp. 145-166.

Katz, M. A., and Byrne, M. D. 2003. "The Effect of Scent and Breadth on Use of Site-Specific Search on E-Commerce Web Sites," ACM Transactions on Human-Computer Interaction (10:3), pp. 198-220.

Keaveney, S. M. 1995. "Customer Switching Behavior in Service Industries: An Exploratory Study,” Journal of Marketing (59:2), pp. 71-82.

Keaveney S. M., and Parthasarathy, M. 2001. "Customer Switching Behavior in Online Services: An Exploratory Study of the Role of Selected Attitudinal, Behavioral, and Demographic Factors," Journal of the Academy of Marketing Science (29:4), pp. 374-390.

Kelley, S. W., Hoffman, K. D., and Davis, M. A. 1993. "A Typology of Retail Failures and Recoveries," Journal of Retailing (64:4), pp. 429-452.

Kettinger, W. J., and Lee, C. C. 2005. "Zones of Tolerance: Alternative Scales for Measuring Information Systems Service Quality," MIS Quarterly (29:4), pp. 607-623. 
Kim, M., Kim J-H., and Lennon, S. J. 2006. "Online Service Attributes Available on Apparel Retail Websites: An E-S-QUAL Approach," Managing Service Quality (16:1), pp. 51-77.

Kim, S. Y., and Lim, Y. J. 2001. "Consumers' Perceived Importance of and Satisfaction with Internet Shopping," Electronic Marketing (11:3), pp. 148-154.

Kim, S., and Stoel, L. 2004. “Apparel Retailers: Website Quality Dimensions and Satisfaction," Journal of Retailing and Consumer Services (11), pp. 109-117.

Korthauer, R. D., and Koubek, R. J. 1994. “An Empirical Evaluation of Knowledge, Cognitive Style, and Structure upon the Performance of a Hypertext Task," International Journal of Human-Computer Interaction (6:4), pp. 373-390.

Lee, E. and MacGregor, J. 1985. "Minimizing User Search Time in Menu Retrieval Systems," Human Factors (27), pp. 157-162.

Lee, M. C. 2009. "Factors Influencing the Adoption of Internet Banking: An Integration of TAM and TPB with Perceived Risk and Perceived Benefit," Electronic Commerce Research and Applications (8:3), pp. 130-141.

Leong, S. M., Ang, S. H., and Low, L H. L. 1997. "Effects of Physical Environment and Locus of Control on Service Evaluation: A Replication and Extension," Journal of Retailing and Consumer Services (4:4), pp. 231-237.

Lightner, N. J. 2004. "Evaluating e-Commerce with a Focus on Customer," Communications of the ACM (47:10), pp. 88-92.

Loiacono, E. T., Watson, R. T., and Goodhue, D. L. 2002. "WEBQUAL: A Measure of Website Quality," in Proceedings of 2002 Marketing Theory and Applications, Chicago, IL, pp. 432-438.

Loiacono, E. T., Watson, R. T., and Goodhue, D. L. 2007. "WebQual: An Instrument for Consumer Evaluation of Web Sites," International Journal of Electronic Commerce (11:3), pp. 51-87.

Luo J., Ba, S., and Zhang, H. 2012. "The Effectiveness of Online Shopping Characteristics and Well-Designed Websites on Satisfaction," MIS Quarterly (36:4), pp. 1131-1144.

Majchrzak, A., Chellappa, R. K., and Cooper, L. P. 2005. "Personalizing Knowledge Delivery Services: A Conceptual Framework," in New Frontiers in Knowledge Management, K. C. DeSouza (ed.), New York: Palgrave-Macmillan, 2005, pp. 51-71.

Martin, G. L., and Corl, K. G. 1986. "System Response Time Effects on User Productivity," Behavior and Information Technology (5:1), pp. 3-13.

Marx, A. 2010. "Crisp-Set Qualitative Comparative Analysis (csQCA) and Model Specification: Benchmarks for Future csQCA Applications," International Journal of Multiple Research Approaches (4:2), pp. 138-158.

Marx, A., and Dusa, A. 2011. "Crisp-Set Qualitative Comparative Analysis (csQCA), Contradictions and Consistency Benchmarks for Model Specification," Methodological Innovations Online (6:2), pp. 103-148.

Maxham III, J. G., and Netemeyer, R. G. 2002. “A Longitudinal Study of Complaining Customers' Evaluations of Multiple Service Failures and Recovery Efforts," Journal of Marketing (66:4), pp. 57-71.
McColl-Kennedy, J. R., and Sparks, B. A. 2003. "Application of Fairness Theory to Service Failures and Service Recovery," Journal of Service Research (5:3), pp. 251-266.

McKinney, V., Yoon, K., and Zahedi, F. 2002. "The Measurement of Web-Customer Satisfaction: An Expectation and Disconfirmation Approach," Information Systems Research (13:3), pp. 296-315.

Melian-Alzola, L., and Padron-Robaina, V. 2006. "Tangibility as a Quality Factor in Electronic Commerce B2C," Managing Service Quality (16:3), pp. 320-338.

Muthukrishnan, A. V., and Chattopadhyay, A. 2007. "Just Give Me Another Chance: The Strategies for Brand Recovery from a Bad First Impression," Journal of Marketing Research (44:2), pp. 334-345.

Nah, F. 2002. "A Study of Web Users' Waiting Time," in Intelligent Support Systems Technology: Knowledge Management, V. Sugumaran (ed.), Aarhus, Denmark: IRM Press, pp. 145-152.

Nath, A. K., and Singh, R. 2010. "Evaluating the Performance and Quality of Web Services in Electronic Marketplaces," e-Service Journal (7:1), pp. 43-59.

Nickerson, R. C., Varshney, U., and Muntermann, J. 2013. “A Method for Taxonomy Development and its Application in Information Systems," European Journal of Information Systems (22:3), pp. 336-359.

Nielsen Norman Group. 2001. "Did Poor Usability Kill E-Commerce?," Jakob Nielsen's Alertbox, August 19 (available online at http://www.nngroup.com/articles/did-poor-usabilitykill-e-commerce/; accessed August 18, 2013).

O’Neill, M., Wright, C., and Fitz, F. 2001. "Quality Evaluation in Online Service Environments: An Application of the Importance-Performance Measurement Technique," Managing Service Quality (11:6), pp. 402-417.

Oliver, R. L. 1997. Satisfaction: A Behavioral Perspective on the Consumer, New York: McGraw-Hill.

Oliver, R. L. 1980. "A Cognitive Model of the Antecedents and Consequences of Satisfaction Decisions," Journal of Marketing Research (17:4), pp. 460-469.

Oliver, R. L. 1981. "Measurement and Evaluation of the Satisfaction Process in Retail Settings," Journal of Retailing (57:3), pp. 25-48.

Oliver, R. L., and Swan, J. E. 1989. "Equity and Disconfirmation Perceptions as Influences on Merchant and Product Satisfaction," Journal of Consumer Research (16:3), pp. 372-383.

Oneupweb. 2010. "Revolutionizing Website Design: The New Rules of Usability," Oneupweb (available online at http://www.oneupweb.com/landing/10_usability_study/?source =pitchengine_2010usability_060910\&guid=7F4760D7-3B72DF11-9242-0010B5500080\#; accessed January 27, 2011).

Palmer, J. W. 2002. "Web Site Usability, Design and Performance Metrics," Information Systems Research (13:2), pp. 151-167.

Parasuraman, A., Berry, L. L., and Zeithaml, V. A. 1985. "A Conceptual Model of Service Quality and its Implications for Future Research," Journal of Marketing (49:4), pp. 41-50.

Parasuraman, A., Berry, L. L., and Zeithaml, V. A. 1988. "SERVQUAL: A Multiple-Item Scale for Measuring Customer Perceptions of Service Quality," Journal of Retailing (64:1), pp. 12-40. 
Parasuraman, A., Zeithaml, V. A., and Malhotra, A. 2005. "E-SQual: A Multiple-Item Scale for Assessing Electronic Service Quality," Journal of Service Research (7:3), pp. 213-233.

Parkhurst, E. 2013. "Amazon.com Goes Down; Outage Could Cost \$5M," Puget Sound Business Journal (available online at http://www.bizjournals.com/seattle/blog/techflash/2013/08/ amazoncom-has-gone-down.html; accessed September 7, 2013).

Petter, S., DeLone, W., and McLean E. R. 2013. "Information Systems Success: The Quest for the Independent Variables," Journal of Management Information Systems (29:4), pp. 7-61.

Piccoli, G., Spalding, B. R., and Ives, B. 2001. "The CustomerService Life Cycle: A Framework for Improving Customer Service through Information Technology," Cornell Hotel and Restaurant Administration Quarterly (42:3), pp. 38-45.

Ragin, C. C., Rubinson, C., Schaefer, D., Anderson, S., Williams, E. and Giesel, H. 2006. User's Guide to Fuzzy-Set/Qualitative Comparative Analysis 2.0, Department of Sociology, University of Arizona, Tucson, AZ.

Rai, A., Lang, S. S., and Welker, R. B. 2002. "Assessing the Validity of IS Success Models: An Empirical Test and Theoretical Analysis," Information Systems Research (13:1), pp. 50-69.

Ranganathan, C., and Ganapathy, S. 2002. "Key Dimensions of Business-to-Consumer Web Sites," Information \& Management (39:6), pp. 457-465.

Ribbink, D., van Riel, A. C. R., Liljander, V., and Streukens, S. 2004. "Comfort Your Online Customer: Quality, Trust, and Loyalty on the Internet," Managing Service Quality (14:6), pp. 446-456.

Rose, G., Khoo, H., and Straub, D. W. 1999. "Current Technological Impediments to Business-to-Consumer Electronic Commerce," Communications of the AIS (1:5).

Rose, G. M., and Straub, D. 2001. "The Effect of Download Time on Consumer Attitude Toward the E-Service Retailer," e-Service Journal (1:1), pp. 55-76.

Santos, J. 2003. "E-Service Quality: A Model of Virtual Service Quality Dimensions," Management Service Quality (13:3), pp. 233-246.

Santos, J., and Boote, J. 2003. "A Theoretical Exploration and Model of Consumer Expectation, Post-Purchase Affective States and Affective Behavior," Journal of Consumer Behavior (3:2), pp. 142-156.

Sears, A., Jacko, J. A., and Dubach, E. M. 2000. "International Aspects of WWW Usability and the Role of High-End Graphical Enhancements," International Journal of Human-Computer Interaction (12:2), pp. 243-263.

Seddon P. B. 1997. "A Respecification and Extension of the DeLone and McLean Model of IS Success," Information Systems Research (8:3), pp. 240-253.

Semeijn, J., van Riel, A. C. R., van Birgelen, M. J. H., and Streukens, S. 2005. "E-Services and Offline Fulfillment: How E-Loyalty is Created," Managing Service Quality (15:2), pp. 182-194.

Serenko, A. 2006. "The Use of Interface Agents for Email Notification in Critical Incidents," International Journal of HumanComputer Studies (64:11), pp. 1084-1098.
Shim, J. P., Shin, Y. B., and Nottingham, L. 2002. "Retailer Web Site Influence on Customer Shopping: An Exploratory Study on Key Factors of Customer Satisfaction," Journal of the Association for Information Systems (3:1), pp. 53-76.

Singh, M. 2002. "E-Services and their Role in B2C E-Commerce," Managing Service Quality (12:6), pp. 434-446.

Smith, A. K., Bolton, R. N., and Wagner, J. 1999. "A Model of Customer Satisfaction with Service Encounters Involving Failure and Recovery," Journal of Marketing Research (36:3), pp. 356-372.

Srinivasan, S. S., Anderson, R., and Ponnavolu, K. 2002. "Customer Loyalty in E-Commerce: An Exploration of its Antecedents and Consequences," Journal of Retailing (78:1), pp. 41-50.

Straub, D. W., and Watson, R. T. 2001. "Research Commentary: Transformational Issues in Researching IS and Net-Enabled Organizations," Information Systems Research (12:4), pp. 337-345.

Surjadjaja, H., Ghosh, S., and Antony, J. 2003. "Determining and Assessing the Determinants of E-Service Operations," Managing Service Quality (13:1), pp. 39-53.

Tan, C. W., and Benbasat, I. 2009. "IT-Mediated Customer Services in E-Government: A Citizen's Perspective," Communications of the AIS (24:12), pp. 175-198.

Tan, C. W., Benbasat, I., and Cenfetelli, R. 2013. "IT-Mediated Customer Service Content and Delivery in Electronic Governments: An Empirical Investigation of the Antecedents of Service Quality,” MIS Quarterly (37:1), pp. 77-109.

Tate, M., and Evermann, J. 2010. "The End of ServQual in Online Services Research: Where to From Here," e-Service Journal (7:1), pp. 60-85.

Taylor, S. 1994. "Waiting for Service: The Relationship between Delays and Evaluations of Service," Journal of Marketing (58:2), pp. 56-69.

Thomas, D. M., and Bostrom, R. P. 2010a. "Team Leader Strategies for Enabling Collaboration Technology Adaptation: Team Technology Knowledge to Improve Globally Distributed Systems Development Work," European Journal of Information Systems (19:3), pp. 223-237.

Thomas, D. M., and Bostrom, R. P. 2010b. "Vital Signs for Virtual Teams: An Empirically Developed Trigger Model for Technology Adaptation Interventions," MIS Quarterly (34:1), pp. 115-142.

Torkzadeh, G., and Dhillon, G. 2002. "Measuring Factors that Influence the Success of Internet Commerce," Information Systems Research, (13:2), pp. 187-204.

Tsiros, M. and Mittal, V. 2000. "Regret: A Model of its Antecedents and Consequences in Consumer Decision Making," Journal of Consumer Research (26:4), pp. 401-417.

Vandenbosch, B., and Huff, S. L. 1997. "Searching and Scanning: How Executives Obtain Information from Executive Information Systems," MIS Quarterly (21:1), pp. 81-107.

Venkatesh, V., Morris, M. G., Davis, G. B., and Davis, F. D. 2003. "User Acceptance of Information Technology: Toward a Unified View," MIS Quarterly (27:3), pp. 425-478.

Viney, L. L. 1983. "The Assessment of Psychological States Through Content Analysis of Verbal Communications," Psychological Bulletin (94:3), pp. 542-563. 
Waite, K., and Harrison, T. 2002. "Consumer Expectations of Online Information Provided by Bank Websites," Journal of Financial Services Marketing (6:4), pp. 309-322.

Wand, Y., and Wang, R. Y. 1996. "Anchoring Data Quality Dimensions in Ontological Foundations," Communications of the $A C M(39: 11)$, pp. 86-95.

Wang, R. Y., and Strong, D. M. 1996. "Beyond Accuracy: What Data Quality Means to Data Consumers," Journal of Management Information Systems (12:4), pp. 5-34.

Warden, C. A., Liu, T. C., Huang, C. T., and Lee, C. H. 2003. "Service Failures Away from Home: Benefits in Intercultural Service Encounters," International Journal of Service Industry Management (14:4), pp. 436-456.

Webler, T., Rakel, H., Renn, O., and Johnson, B. 1995. "Eliciting and Classifying Concerns: A Methodological Critique," Risk Analysis (15:3) pp 421-436.

Wind, Y. J. 2001. "The Challenge of 'Customerization' in Financial Services," Communications of the ACM (44:6), pp. 39-44.

Wixom, B. H., and Todd, P. A. 2005. "A Theoretical Integration of User Satisfaction and Technology Acceptance," Information Systems Research (16:1), pp. 85-102.

Wixom, B. H., and Watson, H. J. 2001. "An Empirical Investigation of the Factors Affecting Data Warehousing Success," MIS Quarterly (25:1), pp. 17-41.

Wolfinbarger, M., and Gilly, M. C. 2003. "eTailQ: Dimensionalizing, Measuring and Predicting etail Quality," Journal of Retailing (79:3), pp. 183-198.

Xiao, B., and Benbasat, I. 2007. "E-Commerce Product Recommendation Agents: Use, Characteristics, and Impact," MIS Quarterly (31:1), pp. 137-209.

Xiao, B., and Benbasat, I. 2011. "Product-Related Deception in e-Commerce: A Theoretical Perspective," MIS Quarterly (35:1), pp. 169-195.

Xu, D., Benbasat, I., and Cenfetelli, R. 2013. "Integrating Service Quality with System and Information Quality: An Empirical Test in the E-Service Context," MIS Quarterly (37:1), pp. 777-794.

Yi, Y. 1990. "A Critical Review of Consumer Satisfaction?," in Review of Marketing 1990, V. A. Zeithaml (ed.), Chicago: American Marketing Association, pp. 68-123.

Zeithaml, V. A. 2002. "Service Excellence in Electronic Channels," Managing Service Quality (12:3), pp. 135-138.

Zeithaml, V. A., Berry, L. L., and Parasuraman, A. 1993. "The Nature and Determinants of Customer Expectations of Service," Journal of the Academy of Marketing Science (21:1), pp. 1-12.

Zeithaml, V. A., Berry, L. L., and Parasuraman, A. 1996. "The Behavioral Consequences of Service Quality," Journal of Marketing (60:2), pp. 31-46.

Zeithaml, V. A., Parasuraman, A., and Malhotra, A. 2002. "Service Quality Delivery through Web Sites: A Critical Review of Extant Knowledge," Journal of the Academy of Marketing Science (30:4), pp. 362-375.

\section{About the Authors}

Chee-Wee Tan is an associate professor in the Department of IT Management at the Copenhagen Business School. He holds a Ph.D. in Business Administration from the University of British Columbia as well as Master of Science and Bachelor of Science degrees from the National University of Singapore. His primary research interests focus on design and innovation issues related to the delivery of digital services in various contexts. Particularly, he is interested in discovering how value can be extracted from digital services and exploring ways by which contemporary technological trends can contribute to the design of innovative services. His research has been published in MIS Quarterly, Information Systems Research, Journal of the American Society for Information Science and Technology, European Journal of Information Systems, and Decision Support Systems, among others. He currently serves as an associate editor for MIS Quarterly.

Izak Benbasat is a Fellow of the Royal Society of Canada and Sauder Distinguished Professor of Information Systems at the Sauder School of Business, University of British Columbia. He received his $\mathrm{Ph} . \mathrm{D}$. in Management Information Systems from the University of Minnesota. He received the LEO Award for Lifetime Exceptional Achievements in Information Systems from the Association for Information Systems in 2007, and was conferred the title of Distinguished Fellow by the Institute for Operations Research and Management Sciences (INFORMS) Information Systems Society in 2009. He currently serves on the editorial boards of Journal of the Association for Information Systems and Journal of Management Information Systems. He was editor-in-chief of Information Systems Research, editor of the Information Systems and Decision Support Systems Department of Management Science, and a senior editor of MIS Quarterly. The general theme of his research is improving the communication between information technology, management, and IT users.

Ronald T. Cenfetelli is associate professor and chair of the Management Information Systems Division at the Sauder School of Business, University of British Columbia. He holds a Ph.D. from the University of British Columbia, an M.B.A. from Indiana University and a B.S. in engineering from Purdue University. Ron's research interests are in e-business, the behavioral and emotional aspects of technology usage, and psychometrics. Ron publishes regularly in Information Systems Research and MIS Quarterly. He currently serves as an associate editor for MIS Quarterly. He has been recognized as both the Reviewer of the Year (2010) and Outstanding Associate Editor (2013) for MIS Quarterly. He is also a past director of the Chief Information Officer Association of Canada. 


\section{AN EXPLORATORY STUDY OF THE FORMATION AND IMPACT OF ELECTRONIC SERVICE FAILURES}

\section{Chee-Wee Tan}

Department of IT Management, Copenhagen Business School, Howitzvej 60,

Fredericksberg 2000 DENMARK \{cta.itm@cbs.dk\}

Izak Benbasat and Ronald T. Cenfetelli

Sauder School of Business, University of British Columbia, 2053 Main Mall,

Vancouver, BC V6T 1 Z2 CANADA \{izak.benbasat@sauder.ubc.ca\} \{cenfetelli@sauder.ubc.ca\}

\section{Appendix A}

\section{Summary of Extant Literature on Service Failure}

\begin{tabular}{|c|c|c|c|c|c|c|}
\hline Author(s) & $\begin{array}{l}\text { Theoretical } \\
\text { Frame of } \\
\text { Reference }\end{array}$ & $\begin{array}{l}\text { Scope of } \\
\text { Application }\end{array}$ & $\begin{array}{l}\text { Dimensions + [Sub- } \\
\text { Dimensions] }\end{array}$ & Consequence(s) & Methodology & Findings/Proposition \\
\hline $\begin{array}{l}\text { Bitner } \\
(1990)\end{array}$ & $\begin{array}{l}\text { Attribution } \\
\text { Theory and } \\
\text { Expectation } \\
\text { Disconfirm- } \\
\text { ation Theory }\end{array}$ & $\begin{array}{l}\text { Offline } \\
\text { Service } \\
\text { Failure }\end{array}$ & $\begin{array}{l}\text { Unidimensional Failure } \\
\text { Construct }\end{array}$ & Dissatisfaction & $\begin{array}{l}\text { Field } \\
\text { experimental } \\
\text { study involving } \\
145 \text { participants } \\
\text { respectively }\end{array}$ & $\begin{array}{l}\text { - Consumers are likely to be } \\
\text { dissatisfied when they deem that } \\
\text { the service provider exercise } \\
\text { greater control over the cause of } \\
\text { a service failure, and when the } \\
\text { failure was recurring vis-à-vis a } \\
\text { rare event } \\
\text { - Consumers tend to attribute } \\
\text { service failure to a lack of control } \\
\text { on the part of the service } \\
\text { provider when an external } \\
\text { explanation is offered for the } \\
\text { failure } \\
\text { - Consumers tend to view service } \\
\text { failure as a rare event when the } \\
\text { failure occurred in an organized } \\
\text { service environment }\end{array}$ \\
\hline
\end{tabular}




\begin{tabular}{|c|c|c|c|c|c|c|}
\hline Author(s) & $\begin{array}{l}\text { Theoretical } \\
\text { Frame of } \\
\text { Reference }\end{array}$ & $\begin{array}{l}\text { Scope of } \\
\text { Application }\end{array}$ & $\begin{array}{l}\text { Dimensions + [Sub- } \\
\text { Dimensions] }\end{array}$ & Consequence(s) & Methodology & Findings/Proposition \\
\hline $\begin{array}{l}\text { Bitner et al. } \\
(1990)\end{array}$ & None & $\begin{array}{l}\text { Offline } \\
\text { Service } \\
\text { Encounter } \\
\text { Failure }\end{array}$ & $\begin{array}{l}\text { Failure of Service Delivery } \\
\text { System [unavailable service, } \\
\text { unreasonably slow service, } \\
\text { and other core service failure] } \\
\text { Failure to Meet Customer } \\
\text { Needs and Requests } \\
\text { [Failure to meet special needs } \\
\text { customers, failure to meet } \\
\text { customer preferences, failure } \\
\text { to address admitted customer } \\
\text { error, and failure to manage } \\
\text { disruptive others] } \\
\text { Unprompted and } \\
\text { Unsolicited Service } \\
\text { Behaviors [Failure to pay } \\
\text { attention to customer, failure } \\
\text { due to out-of-the-ordinary } \\
\text { service behavior, failure to be } \\
\text { sensitive to cultural norms, } \\
\text { gestalt evaluation failure, and } \\
\text { failure to perform under } \\
\text { adverse circumstances] }\end{array}$ & None & $\begin{array}{l}\text { Critical Incident } \\
\text { Technique (CIT) } \\
\text { involving } 352 \\
\text { incidents of } \\
\text { dissatisfied } \\
\text { service } \\
\text { encounters from } \\
\text { service } \\
\text { industries }\end{array}$ & $\begin{array}{l}\text { - Inductively derive a classification } \\
\text { system of service encounter } \\
\text { failures comprising three } \\
\text { categories (i.e., failure of service } \\
\text { delivery system, failure to meet } \\
\text { customer needs and requests as } \\
\text { well as unprompted, and } \\
\text { unsolicited service behaviors), } \\
\text { each with its own set of } \\
\text { constituent sub-dimensions }\end{array}$ \\
\hline $\begin{array}{l}\text { Bitner et al. } \\
(1994)\end{array}$ & None & $\begin{array}{l}\text { Offline } \\
\text { Service } \\
\text { Encounter } \\
\text { Failure }\end{array}$ & $\begin{array}{l}\text { - Failure of Service Delivery } \\
\text { System [Unavailable service, } \\
\text { unreasonably slow service, } \\
\text { and other core service failure] } \\
\text { - Failure to Meet Customer } \\
\text { Needs and Requests } \\
\text { [Failure to meet special needs } \\
\text { customers, failure to meet } \\
\text { customer preferences, failure } \\
\text { to address admitted customer } \\
\text { error, and failure to manage } \\
\text { disruptive others] } \\
\text { - Unprompted and } \\
\text { Unsolicited Service } \\
\text { Behaviors [Failure to pay } \\
\text { attention to customer, failure } \\
\text { due to out-of-the-ordinary } \\
\text { service behavior, failure to be } \\
\text { sensitive to cultural norms, } \\
\text { gestalt evaluation failure, and } \\
\text { failure to perform under } \\
\text { adverse circumstances] } \\
\text { Failure to Address } \\
\text { Problematic Customer } \\
\text { Behavior [Failure to address } \\
\text { drunken customers, failure to } \\
\text { address verbal and physical } \\
\text { abuse, failure to address } \\
\text { customers breaking company } \\
\text { laws or policies, and failure to } \\
\text { address uncooperative } \\
\text { customers] }\end{array}$ & None & $\begin{array}{l}\text { Critical Incident } \\
\text { Technique (CIT) } \\
\text { involving } 774 \\
\text { incidents of } \\
\text { dissatisfied } \\
\text { service } \\
\text { encounters from } \\
\text { service } \\
\text { industries }\end{array}$ & $\begin{array}{l}\text { - Inductively derive a classification } \\
\text { system of service encounter } \\
\text { failures comprising four cate- } \\
\text { gories (i.e., failure of service } \\
\text { delivery system, failure to meet } \\
\text { customer needs and requests, } \\
\text { unprompted and unsolicited } \\
\text { service behaviors as well as } \\
\text { failure to address problematic } \\
\text { customer behavior), each with its } \\
\text { own set of constituent sub- } \\
\text { dimensions }\end{array}$ \\
\hline $\begin{array}{l}\text { Colgate and } \\
\text { Norris } \\
(2001)\end{array}$ & None & $\begin{array}{l}\text { Offline } \\
\text { Service } \\
\text { Failure }\end{array}$ & $\begin{array}{l}\text { Unidimensional Failure } \\
\text { Construct }\end{array}$ & $\begin{array}{l}\text { - Customer Exit } \\
\text { - Customer } \\
\text { Retention }\end{array}$ & $\begin{array}{l}\text { Face-to-face, in- } \\
\text { depth interviews } \\
\text { with } 20 \\
\text { respondents }\end{array}$ & $\begin{array}{l}\text { - In the absence of barriers of exit } \\
\text { and customer loyalty, consumers } \\
\text { are likely to exit when they are } \\
\text { dissatisfied with recovery efforts } \\
\text { on the part of the service } \\
\text { provider upon encountering a } \\
\text { service failure }\end{array}$ \\
\hline
\end{tabular}




\begin{tabular}{|c|c|c|c|c|c|c|}
\hline Author(s) & $\begin{array}{l}\text { Theoretical } \\
\text { Frame of } \\
\text { Reference }\end{array}$ & $\begin{array}{l}\text { Scope of } \\
\text { Application }\end{array}$ & $\begin{array}{l}\text { Dimensions + [Sub- } \\
\text { Dimensions] }\end{array}$ & Consequence(s) & Methodology & Findings/Proposition \\
\hline $\begin{array}{l}\text { DeWitt and } \\
\text { Brady } \\
(2003)\end{array}$ & None & $\begin{array}{l}\text { Offline } \\
\text { Service } \\
\text { Failure }\end{array}$ & $\begin{array}{l}\text { Unidimensional Failure } \\
\text { Construct }\end{array}$ & $\begin{array}{l}\text { Post-failure } \\
\text { Customer } \\
\text { Satisfaction } \\
\text { - Re-patronage } \\
\text { Intentions } \\
\text { - Word-of- } \\
\text { mouth }\end{array}$ & $\begin{array}{l}\text { Four survey } \\
\text { studies involving } \\
291,148,40, \\
\text { and } 126 \text { respon- } \\
\text { dents respec- } \\
\text { tively }\end{array}$ & $\begin{array}{l}\text { Existing rapport between } \\
\text { consumers and service providers } \\
\text { culminates in increased post- } \\
\text { failure customer satisfaction, } \\
\text { increased re-patronage } \\
\text { intentions and decreased } \\
\text { negative word of mouth upon } \\
\text { encountering service failure } \\
\text { - Existing rapport between } \\
\text { consumers and service providers } \\
\text { does not lead to higher } \\
\text { propensity for consumers to } \\
\text { complain about service failure }\end{array}$ \\
\hline $\begin{array}{l}\text { Folkes } \\
(1984)\end{array}$ & $\begin{array}{l}\text { Attribution } \\
\text { Theory }\end{array}$ & $\begin{array}{l}\text { Product } \\
\text { Failure }\end{array}$ & $\begin{array}{l}\text { Unidimensional Failure } \\
\text { Construct }\end{array}$ & $\begin{array}{l}\text { - Expectancy } \\
\text { Reactions } \\
\text { - Marketplace } \\
\text { Equity } \\
\text { Reactions } \\
\text { - Anger } \\
\text { Reactions }\end{array}$ & $\begin{array}{l}\text { Two experi- } \\
\text { mental studies } \\
\text { involving } 61 \text { and } \\
56 \text { participants } \\
\text { respectively }\end{array}$ & $\begin{array}{l}\text { - Attribution of stability of product } \\
\text { failure influences consumers' } \\
\text { expectancy reactions in that } \\
\text { consumers are likely to prefer } \\
\text { refunds over exchanges when } \\
\text { product failure is deemed to be } \\
\text { stable } \\
\text { - Attribution of locus of product } \\
\text { failure influences consumers' } \\
\text { marketplace equity reactions in } \\
\text { that consumers are likely to feel } \\
\text { deserving of not being charged } \\
\text { and of receiving an apology } \\
\text { when product failure is deemed } \\
\text { to be caused by service } \\
\text { providers } \\
\text { - Attribution of controllability of } \\
\text { product failure influences } \\
\text { consumers' anger reactions in } \\
\text { that consumers are likely to be } \\
\text { angrier and vengeful when } \\
\text { product failure is deemed to be } \\
\text { controllable }\end{array}$ \\
\hline $\begin{array}{l}\text { Hess et al. } \\
(2007)\end{array}$ & $\begin{array}{l}\text { Stereotyping } \\
\text { Theory }\end{array}$ & $\begin{array}{l}\text { Offline } \\
\text { Service } \\
\text { Failure }\end{array}$ & $\begin{array}{l}\text { Unidimensional Failure } \\
\text { Construct } \rightarrow \text { Interactional }\end{array}$ & Dissatisfaction & $\begin{array}{l}\text { Two experi- } \\
\text { mental studies } \\
\text { involving } 288 \\
\text { and } 304 \\
\text { participants } \\
\text { respectively }\end{array}$ & $\begin{array}{l}\text { - Attribution of globality of service } \\
\text { failure and dissatisfaction with } \\
\text { the service provider could be } \\
\text { lowered through excellent past } \\
\text { service } \\
\text { - Excellent past service increases } \\
\text { dissatisfaction with the offending } \\
\text { employee upon encountering } \\
\text { service failure } \\
\text { - Attribution of controllability } \\
\text { influences consumers' generali- } \\
\text { zation of service failure to the } \\
\text { service provider in that con- } \\
\text { sumers are likely to generalize a } \\
\text { service failure to the service } \\
\text { provider rather than the } \\
\text { offending employee when the } \\
\text { service failure is deemed to be } \\
\text { controllable }\end{array}$ \\
\hline
\end{tabular}




\begin{tabular}{|c|c|c|c|c|c|c|}
\hline Author(s) & $\begin{array}{l}\text { Theoretical } \\
\text { Frame of } \\
\text { Reference }\end{array}$ & $\begin{array}{l}\text { Scope of } \\
\text { Application }\end{array}$ & $\begin{array}{l}\text { Dimensions + [Sub- } \\
\text { Dimensions] }\end{array}$ & Consequence(s) & Methodology & Findings/Proposition \\
\hline $\begin{array}{l}\text { Holloway } \\
\text { and Beatty } \\
\text { (2003) }\end{array}$ & None & $\begin{array}{l}\text { Online } \\
\text { Retail } \\
\text { Failure }\end{array}$ & $\begin{array}{l}\text { - Delivery Problems [Pur- } \\
\text { chase arrived later than } \\
\text { promised, purchase never } \\
\text { delivered, wrong item } \\
\text { delivered, wrong size product } \\
\text { delivered, and purchase } \\
\text { damaged during delivery] } \\
\text { - Website Design Problems } \\
\text { [Navigational problems at site, } \\
\text { product poorly presented at } \\
\text { site, insufficient information } \\
\text { provided at site, products } \\
\text { incorrectly listed at site as in } \\
\text { stock, and incorrect } \\
\text { information provided at site] } \\
\text { - Customer Service Problems } \\
\text { [Poor customer service } \\
\text { support, poor communication } \\
\text { with the company, unfair } \\
\text { return policies, and unclear } \\
\text { return policies] } \\
\text { - Payment Problems [Credit } \\
\text { card overcharged, website } \\
\text { purchasing process con- } \\
\text { fusing, difficulties experienced } \\
\text { while paying, problems with } \\
\text { product quality, and consumer } \\
\text { dissatisfied with product } \\
\text { quality] } \\
\text { - Security Problems [Credit } \\
\text { card fraud, misrepresented } \\
\text { merchandise, and email } \\
\text { address released to } \\
\text { e-marketers] } \\
\text { - Miscellaneous [Failure to } \\
\text { address unintentional cus- } \\
\text { tomer mistakes, retailer } \\
\text { charged some customers } \\
\text { more than others, and lack of } \\
\text { personalized information at } \\
\text { site] } \\
\end{array}$ & None & $\begin{array}{l}\text { Interviews con- } \\
\text { ducted with } 30 \\
\text { individuals with } \\
\text { prior experi- } \\
\text { ences of } \\
\text { e-commerce } \\
\text { service failures } \\
\text { before } \\
\text { surveying } \\
\text { another } 295 \\
\text { online shoppers }\end{array}$ & $\begin{array}{l}\text { - Inductively derive a classification } \\
\text { system of online retail failures } \\
\text { comprising seven categories } \\
\text { (i.e., delivery problems, website } \\
\text { design problems, customer } \\
\text { service problems, payment } \\
\text { problems, security problems, } \\
\text { and miscellaneous), each with its } \\
\text { own set of constituent sub- } \\
\text { dimensions }\end{array}$ \\
\hline $\begin{array}{l}\text { Keaveney } \\
\text { (1995) }\end{array}$ & None & $\begin{array}{l}\text { Offline } \\
\text { Service- } \\
\text { Switching } \\
\text { Failure }\end{array}$ & $\begin{array}{l}\text { - Pricing [High price, price } \\
\text { increase, unfair pricing, and } \\
\text { deceptive pricing] } \\
\text { - Inconvenience } \\
\text { [Location/hours, wait for } \\
\text { appointment, and wait for } \\
\text { service] } \\
\text { - Core Service Failure } \\
\text { [Service mistakes, billing } \\
\text { errors, and service } \\
\text { catastrophe] } \\
\text { - Service Encounter Failure } \\
\text { [Uncaring, impolite, } \\
\text { unresponsive, and } \\
\text { unknowledgeable] } \\
\text { - Response to Service Failure } \\
\text { [Negative response, no } \\
\text { response, and reluctant } \\
\text { response] } \\
\text { - Competition [Found better } \\
\text { service] } \\
\text { - Ethical Problems [Cheat, } \\
\text { hard sell, unsafe, and conflict } \\
\text { of interest] } \\
\text { - Involuntary Switching } \\
\text { [Customer moved and } \\
\text { provider closed] }\end{array}$ & $\begin{array}{l}\text { Service } \\
\text { Switching } \\
\text { Behavior }\end{array}$ & $\begin{array}{l}\text { Critical Incident } \\
\text { Technique (CIT) } \\
\text { involving } 838 \\
\text { incidents of } \\
\text { service-switchin } \\
\mathrm{g} \text { behaviors } \\
\text { from service } \\
\text { industries }\end{array}$ & $\begin{array}{l}\text { Inductively derive a classification } \\
\text { system of service-switching failures } \\
\text { comprising eight categories (i.e., } \\
\text { pricing, inconvenience, core } \\
\text { service failure, service encounter } \\
\text { failure, response to service failure, } \\
\text { competition, ethical problems, and } \\
\text { involuntary switching), each with its } \\
\text { own set of constituent sub- } \\
\text { dimensions }\end{array}$ \\
\hline
\end{tabular}




\begin{tabular}{|c|c|c|c|c|c|c|}
\hline Author(s) & $\begin{array}{l}\text { Theoretical } \\
\text { Frame of } \\
\text { Reference }\end{array}$ & $\begin{array}{l}\text { Scope of } \\
\text { Application }\end{array}$ & $\begin{array}{l}\text { Dimensions + [Sub- } \\
\text { Dimensions] }\end{array}$ & Consequence(s) & Methodology & Findings/Proposition \\
\hline $\begin{array}{l}\text { Kelley et al. } \\
\text { (1993) }\end{array}$ & None & $\begin{array}{l}\text { Offline } \\
\text { Retail } \\
\text { Failure }\end{array}$ & $\begin{array}{l}\text { Failure of Service Delivery } \\
\text { System and/or Product } \\
\text { [Policy failure, slow/unavail- } \\
\text { able service, system pricing } \\
\text { failure, packaging errors, } \\
\text { product defects, out-of-stock, } \\
\text { hold disasters, alteration and } \\
\text { repairs failure, and bad } \\
\text { information] } \\
\text { - Failure to Meet Customer } \\
\text { Needs and Requests } \\
\text { [Special order/request failure } \\
\text { and failure to address } \\
\text { admitted customer error] } \\
\text { - Unprompted and } \\
\text { Unsolicited Service } \\
\text { Behaviors [Mischarging, } \\
\text { wrongful accusation of } \\
\text { customers, failure due to } \\
\text { service-induced embarras- } \\
\text { sment, and attention failures] }\end{array}$ & None & $\begin{array}{l}\text { Critical Incident } \\
\text { Technique }(\mathrm{CIT}) \\
\text { involving } 661 \\
\text { incidents of } \\
\text { service failures } \\
\text { in general } \\
\text { merchandise } \\
\text { retailing }\end{array}$ & $\begin{array}{l}\text { - Inductively derive a classification } \\
\text { system of retail failures com- } \\
\text { prising three categories (i.e., } \\
\text { failure of service delivery system } \\
\text { and/or product, failure to meet } \\
\text { customer needs and requests as } \\
\text { well as unprompted, and } \\
\text { unsolicited service behaviors), } \\
\text { each with its own set of } \\
\text { constituent sub-dimensions }\end{array}$ \\
\hline $\begin{array}{l}\text { Leong et al. } \\
\text { (1997) }\end{array}$ & $\begin{array}{l}\text { Attribution } \\
\text { Theory }\end{array}$ & $\begin{array}{l}\text { Offline } \\
\text { Service } \\
\text { Failure }\end{array}$ & $\begin{array}{l}\text { Unidimensional Failure } \\
\text { Construct }\end{array}$ & Dissatisfaction & $\begin{array}{l}\text { Experimental } \\
\text { study involving } \\
108 \text { participants }\end{array}$ & $\begin{array}{l}\text { - Consumers are likely to be } \\
\text { dissatisfied when they deem that } \\
\text { the service provider exercise } \\
\text { greater control over the cause of } \\
\text { a service failure, and when the } \\
\text { failure was recurring vis-à-vis a } \\
\text { rare event } \\
\text { - Consumers tend to attribute } \\
\text { service failure to a lack of control } \\
\text { on the part of the service } \\
\text { provider when the failure } \\
\text { occurred in a more pleasant } \\
\text { environment }\end{array}$ \\
\hline $\begin{array}{l}\text { Maxham } \\
\text { and } \\
\text { Netemeyer } \\
(2002)\end{array}$ & $\begin{array}{l}\text { Attribution } \\
\text { Theory, } \\
\text { Expectation } \\
\text { Disconfirmati } \\
\text { on Theory } \\
\text { and Prospect } \\
\text { Theory }\end{array}$ & $\begin{array}{l}\text { Service } \\
\text { Failure }\end{array}$ & $\begin{array}{l}\text { Unidimensional Failure } \\
\text { Construct }\end{array}$ & $\begin{array}{l}\text { - Satisfaction } \\
\text { - Repurchase } \\
\text { Intent } \\
\text { - Word of } \\
\text { Mouth }\end{array}$ & $\begin{array}{l}\text { Repeated } \\
\text { measures field } \\
\text { survey study } \\
\text { involving } 1356 \\
\text { respondents }\end{array}$ & $\begin{array}{l}\text { - Consumers are likely to rate } \\
\text { satisfaction, repurchase intent, } \\
\text { and word of mouth higher for } \\
\text { satisfactory recovery upon } \\
\text { encountering a service failure, } \\
\text { but the effect diminishes after } \\
\text { encountering more than one } \\
\text { service failure } \\
\text { - Consumers are likely to discount } \\
\text { the effects of one service failure } \\
\text { when the service provider has } \\
\text { consistently provided satisfactory } \\
\text { recovery } \\
\text { - Consumer ratings of satisfaction, } \\
\text { repurchase intent, and word of } \\
\text { mouth tend to be influenced by } \\
\text { the most recent recovery when } \\
\text { inconsistent recovery efforts are } \\
\text { practiced by the service provider } \\
\text { for multiple service failures } \\
\text { - Consumers are likely to rate the } \\
\text { second service failure more } \\
\text { severely than they rated the first } \\
\text { Consumers are likely to attribute } \\
\text { multiple service failures to stable } \\
\text { causes of the service provider } \\
\text { - Consumers are likely to rate the } \\
\text { satisfaction, repurchase intent, } \\
\text { and word of mouth lower for } \\
\text { satisfactory recovery when two } \\
\text { similar service failures were to } \\
\text { occur consecutively and in close } \\
\text { time proximity }\end{array}$ \\
\hline
\end{tabular}




\begin{tabular}{|c|c|c|c|c|c|c|}
\hline Author(s) & $\begin{array}{l}\text { Theoretical } \\
\text { Frame of } \\
\text { Reference }\end{array}$ & $\begin{array}{l}\text { Scope of } \\
\text { Application }\end{array}$ & $\begin{array}{l}\text { Dimensions + [Sub- } \\
\text { Dimensions] }\end{array}$ & Consequence(s) & Methodology & Findings/Proposition \\
\hline $\begin{array}{l}\text { McColl- } \\
\text { Kennedy } \\
\text { and Sparks } \\
(2003)\end{array}$ & $\begin{array}{l}\text { Fairness } \\
\text { Theory }\end{array}$ & $\begin{array}{l}\text { Offline } \\
\text { Service } \\
\text { Failure }\end{array}$ & $\begin{array}{l}\text { Service [Unavailable service } \\
\text { and unreasonably slow } \\
\text { service] } \\
\text { - Service Providers } \\
\text { [Unprompted and unsolicited } \\
\text { employee actions] } \\
\text { - Outside the Service } \\
\text { Provider's Control } \\
\text { - Customer Related }\end{array}$ & None & $\begin{array}{l}\text { Five focus } \\
\text { group studies } \\
\text { involving } 32 \\
\text { participants }\end{array}$ & $\begin{array}{l}\text { Service failure events trigger an } \\
\text { emotional response in con- } \\
\text { sumers, which in turn prompt } \\
\text { them to commence an assess- } \\
\text { ment of the situation, taking into } \\
\text { account elements of procedural } \\
\text { justice, interactional justice, and } \\
\text { distributive justice, while } \\
\text { engaging in counterfactual } \\
\text { thinking and apportioning } \\
\text { accountability }\end{array}$ \\
\hline $\begin{array}{l}\text { Smith et al. } \\
\text { (1999) }\end{array}$ & $\begin{array}{l}\text { Expectation } \\
\text { Disconfirma- } \\
\text { tion Theory } \\
\text { and Justice } \\
\text { Theory }\end{array}$ & $\begin{array}{l}\text { Offline } \\
\text { Service } \\
\text { Failure }\end{array}$ & $\begin{array}{l}\text { - Outcome Failure } \\
\text { - Process Failure }\end{array}$ & $\begin{array}{l}\text { - } \text { Distributive } \\
\text { Justice } \\
\text { - Interactional } \\
\text { Justice } \\
\text { - Procedural } \\
\text { Justice }\end{array}$ & $\begin{array}{l}\text { Two mixed } \\
\text { experimental } \\
\text { studies involving } \\
375 \text { and } 602 \\
\text { participants } \\
\text { respectively }\end{array}$ & $\begin{array}{l}\text { - Consumers are likely to rate } \\
\text { distributive justice, interactional } \\
\text { justice, and procedural justice } \\
\text { higher for satisfactory service } \\
\text { encounters } \\
\text { - Consumers are likely to rate } \\
\text { distributive justice, interactional } \\
\text { justice, and procedural justice } \\
\text { higher when compensation, } \\
\text { apology, and speedy response } \\
\text { are offered respectively upon } \\
\text { encountering service failure } \\
\text { - Consumers are likely to rate } \\
\text { distributive justice higher when } \\
\text { compensation is offered upon } \\
\text { encountering outcome failure } \\
\text { - Consumers are likely to rate } \\
\text { procedural justice higher when } \\
\text { speedy response is offered upon } \\
\text { encountering outcome failure } \\
\text { - Consumers are likely to rate } \\
\text { interactional justice higher when } \\
\text { apology is offered upon } \\
\text { encountering process failure } \\
\text { Consumers are likely to rate } \\
\text { interactional justice higher when } \\
\text { organization-initiated recovery is } \\
\text { offered upon encountering } \\
\text { process failure } \\
\text { - Consumers are likely to rate } \\
\text { distributive justice higher when } \\
\text { compensation is offered upon } \\
\text { encountering service failure of } \\
\text { low magnitude } \\
\text { - Consumers are likely to rate } \\
\text { procedural justice higher when } \\
\text { speedy response is offered upon } \\
\text { encountering service failure of } \\
\text { low magnitude } \\
\text { - Consumers are likely to rate } \\
\text { interactional justice higher when } \\
\text { apology is offered upon } \\
\text { encountering service failure of } \\
\text { low magnitude } \\
\text { - Consumers are likely to rate } \\
\text { interactional justice higher when } \\
\text { organization-initiated recovery is } \\
\text { offered upon service failure of } \\
\text { low magnitude }\end{array}$ \\
\hline
\end{tabular}




\section{Appendix A References}

Bitner, M. J. 1990. "Evaluating Service Encounters: The Effects of Physical Surroundings and Employee Responses,” Journal of Marketing (54:1), pp. 69-82.

Bitner, M. J., Booms, B. H., and Mohr, L. A. 1994. “Critical Service Encounters: The Employee’s Viewpoint,” Journal of Marketing (58:1), pp. 95-106.

Bitner, M. J., Booms, B. H., and Tetreault, M. S. 1990. “The Service Encounter: Diagnosing Favorable and Unfavorable Incidents,” Journal of Marketing (54:1), pp. 71-84.

Colgate, K., and Norris, M. 2001. "Developing a Comprehensive Picture of Service Failure," International Journal of Service Industry Management, (12:3), pp. 215-33.

DeWitt, T., and Brady, M. K. 2003. "Rethinking Service Recovery Strategies," Journal of Service Research (6:2), pp. $193-207$.

Folkes, V. S. 1984. “Consumer Reactions to Product Failure: An Attributional Approach,” Journal of Consumer Research (10:4), pp. 398-409.

Hess Jr., R. L., Ganesan, S., and Klein, N. M. 2007. "Interactional Service Failures in a Pseudorelationship: The Role of Organizational Attributions," Journal of Retailing (83:1), pp. 79-95.

Holloway, B. B., and Beatty, S. E. 2003. "Service Failure in Online Retailing: A Recovery Opportunity,” Journal of Service Research (6:1), pp. 92-105.

Keaveney, S. M. 1995. “Customer Switching Behavior in Service Industries: An Exploratory Study,” Journal of Marketing (59:2), pp. 71-82.

Kelley, S. W., Hoffman, K. D., and Davis, M. A. 1993. “A Typology of Retail Failures and Recoveries,” Journal of Retailing (64:4), pp. 429452

Leong, S. M., Ang, S. H., and Low, L H. L. 1997. "Effects of Physical Environment and Locus of Control on Service Evaluation: A Replication and Extension," Journal of Retailing and Consumer Services (4:4), pp. 231-237.

Maxham III, J. G., and Netemeyer, R. G. 2002. "A Longitudinal Study of Complaining Customers' Evaluations of Multiple Service Failures and Recovery Efforts,” Journal of Marketing (66:4), pp. 57-71.

McColl-Kennedy, J. R., and Sparks, B. A. 2003. "Application of Fairness Theory to Service Failures and Service Recovery," Journal of Service Research (5:3), pp. 251-266.

Smith, A. K., Bolton, R. N., and Wagner, J. 1999. "A Model of Customer Satisfaction with Service Encounters Involving Failure and Recovery,” Journal of Marketing Research (36:3), pp. 356-372. 


\section{Appendix B}

Inductive Categorization of E-Service Literature

\begin{tabular}{|c|c|c|c|c|c|c|c|c|c|c|c|c|c|c|c|c|c|}
\hline \multirow[b]{2}{*}{ Author(s) } & \multirow[b]{2}{*}{ Domain } & \multirow{2}{*}{$\begin{array}{c}\text { Scope of } \\
\text { Application }\end{array}$} & \multirow{2}{*}{$\begin{array}{l}\text { Dimensions + [Sub- } \\
\text { Dimensions] }\end{array}$} & \multicolumn{4}{|c|}{$\begin{array}{l}\text { Information } \\
\text { Attributes }\end{array}$} & \multicolumn{5}{|c|}{ Functional Attributes } & \multicolumn{5}{|c|}{ System Attributes } \\
\hline & & & & ACC & сом & REL & TIM & NER & AID & ALE & $A C Q$ & POP & AES & NAV & ADT & SPD & SEC \\
\hline $\begin{array}{l}\text { Agarwal and } \\
\text { Venkatesh } \\
(2002)\end{array}$ & $\begin{array}{l}\text { Website } \\
\text { Quality }\end{array}$ & $\begin{array}{l}\text { Online } \\
\text { Shopping and } \\
\text { Content } \\
\text { based } \\
\text { Website }\end{array}$ & $\begin{array}{l}\text { - Content [Relevance, media } \\
\text { use, depth/breath, and } \\
\text { current information] } \\
\text { - Ease of Use [Goals, } \\
\text { structure, and feedback] } \\
\text { - Promotion } \\
\text { - Made-for-the-Medium } \\
\text { [Community, } \\
\text { personalization, and } \\
\text { refinement] } \\
\text { - Emotion [Challenge, plot, } \\
\text { character strength, and } \\
\text { pace] }\end{array}$ & & $x$ & $x$ & $x$ & $x$ & & & & $x$ & $x$ & $x$ & $x$ & & \\
\hline $\begin{array}{l}\text { Barnes and } \\
\text { Vidgen } \\
(2001)\end{array}$ & $\begin{array}{l}\text { Website } \\
\text { Quality }\end{array}$ & \begin{tabular}{|l} 
Online \\
Shopping
\end{tabular} & $\begin{array}{l}\text { - Tangibles [Aesthetics and } \\
\text { navigation] } \\
\text { - Reliability [Reliability and } \\
\text { competence] } \\
\text { - Responsiveness [Respon- } \\
\text { siveness and access] } \\
\text { - Assurance [Credibility and } \\
\text { security] } \\
\text { - Empathy [Communication } \\
\text { and understanding the } \\
\text { individual] }\end{array}$ & $x$ & & & $x$ & $x$ & & & & $x$ & $x$ & $x$ & $x$ & $x$ & $x$ \\
\hline $\begin{array}{l}\text { Benlian et al. } \\
\text { (2011) }\end{array}$ & $\begin{array}{l}\text { Service } \\
\text { Quality }\end{array}$ & $\begin{array}{l}\text { Software-as- } \\
\text { a-Service }\end{array}$ & \begin{tabular}{|l} 
- Rapport \\
- Responsiveness \\
- Reliability \\
- Flexibility \\
- Features \\
- Security
\end{tabular} & $x$ & & $x$ & $x$ & $x$ & & & $x$ & $x$ & & & $x$ & $x$ & $x$ \\
\hline $\begin{array}{l}\text { Cai and Jun } \\
\text { (2003) }\end{array}$ & $\begin{array}{l}\text { Service } \\
\text { Quality }\end{array}$ & \begin{tabular}{|l} 
Online \\
Shopping
\end{tabular} & $\begin{array}{l}\text { - Website Design/Content } \\
\text { - Trustworthiness } \\
\text { - Prompt/Reliable Service } \\
\text { - Communication }\end{array}$ & $x$ & $X$ & & $x$ & & & & & $x$ & $x$ & $x$ & & & \\
\hline $\begin{array}{l}\text { Cenfetelli et } \\
\text { al. (2008) }\end{array}$ & $\begin{array}{l}\text { Service } \\
\text { Quality }\end{array}$ & $\begin{array}{l}\text { B2C Online } \\
\text { Shopping }\end{array}$ & $\begin{array}{l}\text { Requirements [Needing, } \\
\text { specifying] } \\
\text { - Acquisition [Sourcing, } \\
\text { ordering, paying, obtaining, } \\
\text { accepting] } \\
\text { - Ownership [Training, } \\
\text { monitoring, maintaining, } \\
\text { upgrading] } \\
\text { - Retirement [Accounting } \\
\text { for, reselling/returning, } \\
\text { replacing, evaluating] } \\
\text { - Service Quality [Tangibles, } \\
\text { reliability, responsiveness, } \\
\text { assurance, empathy] }\end{array}$ & & & & & $x$ & $x$ & $x$ & $x$ & $x$ & $x$ & $x$ & $x$ & $x$ & \\
\hline $\begin{array}{l}\text { Childers et } \\
\text { al. (2001) }\end{array}$ & $\begin{array}{l}\text { Website } \\
\text { Quality }\end{array}$ & \begin{tabular}{|l} 
Online \\
Shopping
\end{tabular} & $\begin{array}{l}\text { - Navigation [Influence ease } \\
\text { of use, and enjoyment] } \\
\text { - Convenience [Influence } \\
\text { usefulness, ease of use, } \\
\text { and enjoyment] } \\
\text { - Substitutability } \\
\text { Experience [Usefulness } \\
\text { and enjoyment] }\end{array}$ & & & & & $x$ & & & & & $x$ & $x$ & & $x$ & \\
\hline
\end{tabular}




\begin{tabular}{|c|c|c|c|c|c|c|c|c|c|c|c|c|c|c|c|c|c|}
\hline \multirow[b]{2}{*}{ Author(s) } & \multirow[b]{2}{*}{ Domain } & \multirow{2}{*}{$\begin{array}{l}\text { Scope of } \\
\text { Application }\end{array}$} & \multirow{2}{*}{$\begin{array}{l}\text { Dimensions + [Sub- } \\
\text { Dimensions] }\end{array}$} & \multicolumn{4}{|c|}{$\begin{array}{c}\text { Information } \\
\text { Attributes }\end{array}$} & \multicolumn{5}{|c|}{ Functional Attributes } & \multicolumn{5}{|c|}{ System Attributes } \\
\hline & & & & ACC & com & REL & TIM & NER & AID & ALE & $A C Q$ & POP & AES & NAV & ADT & SPD & SEC \\
\hline $\begin{array}{l}\text { Chiu et al. } \\
(2007)\end{array}$ & $\begin{array}{l}\text { Informa- } \\
\text { tion } \\
\text { Systems } \\
\text { Quality }\end{array}$ & $\begin{array}{l}\text { Web-Based } \\
\text { Learning } \\
\text { Systems }\end{array}$ & $\begin{array}{l}\text { - Information Quality } \\
\text { [Accuracy, completeness, } \\
\text { ease of understanding, } \\
\text { relevance] } \\
\text { - System Quality } \\
\text { [Availability, ease of use, } \\
\text { reliability, response time] } \\
\text { - Service Quality [Support] }\end{array}$ & $x$ & $x$ & $x$ & & & & & & & $\mathrm{x}$ & $x$ & $\mathrm{x}$ & $x$ & \\
\hline $\begin{array}{l}\text { Collier and } \\
\text { Bienstock } \\
(2003,2006)\end{array}$ & $\begin{array}{l}\text { Service } \\
\text { Quality }\end{array}$ & $\begin{array}{l}\text { Online } \\
\text { Shopping }\end{array}$ & $\begin{array}{l}\text { Process Quality [Privacy, } \\
\text { design, information } \\
\text { accuracy, ease of use, } \\
\text { functionality] } \\
\text { Outcome Quality [Order } \\
\text { timeliness, order accuracy, } \\
\text { order condition] } \\
\text { - Recovery Quality } \\
\text { [Interactive fairness, } \\
\text { procedural fairness, } \\
\text { outcome fairness] }\end{array}$ & $x$ & $x$ & & $x$ & & & & $x$ & $x$ & $x$ & $x$ & & & $\mathrm{x}$ \\
\hline $\begin{array}{l}\text { Connolly et } \\
\text { al. }(2010)\end{array}$ & $\begin{array}{l}\text { Service } \\
\text { Quality }\end{array}$ & $\begin{array}{l}\text { Electronic } \\
\text { Government } \\
\text { Services }\end{array}$ & $\begin{array}{ll}\text { - Efficiency } \\
\text { - System Availability } \\
\text { - Fulfilment } \\
\text { - Privacy } \\
\text { - Responsiveness } \\
\text { - Compensation } \\
\text { - Contact } \\
\end{array}$ & & & & $\mathrm{x}$ & $x$ & & & $\mathrm{x}$ & $x$ & $\mathrm{X}$ & $x$ & & $x$ & $x$ \\
\hline $\begin{array}{l}\text { DeLone and } \\
\text { McLean } \\
\text { (2003) }\end{array}$ & $\begin{array}{l}\text { Informa- } \\
\text { tion } \\
\text { Systems } \\
\text { Quality }\end{array}$ & $\begin{array}{l}\text { Information } \\
\text { Systems }\end{array}$ & \begin{tabular}{|l|} 
- System Quality [Adapt- \\
ability, availability, reliability, \\
response time, usability] \\
- Information Quality \\
[Completeness, ease of \\
understanding, personaliza- \\
tion, relevance, security] \\
- Service Quality [Assur- \\
ance, empathy, \\
responsiveness]
\end{tabular} & & $x$ & $x$ & & & & & & $x$ & $x$ & $x$ & $x$ & $x$ & $x$ \\
\hline $\begin{array}{l}\text { DeLone and } \\
\text { McLean } \\
\text { (2004) }\end{array}$ & $\begin{array}{l}\text { Informa- } \\
\text { tion } \\
\text { Systems } \\
\text { Quality }\end{array}$ & $\begin{array}{l}\text { Online } \\
\text { Shopping }\end{array}$ & \begin{tabular}{|l|} 
System Quality [Usability, \\
availability, download time, \\
ease of use] \\
- Information Quality \\
[Relevance, completeness] \\
- Service Quality \\
[Responsiveness] \\
\end{tabular} & & $x$ & $x$ & & & & & & & $x$ & $x$ & $x$ & $x$ & \\
\hline $\begin{array}{l}\text { Devaraj et al. } \\
(2002)\end{array}$ & $\begin{array}{l}\text { Website } \\
\text { Quality }\end{array}$ & $\begin{array}{l}\text { Online } \\
\text { Shopping }\end{array}$ & $\begin{array}{l}\text { - Ease of Use } \\
\text { - Usefulness } \\
\text { - Asset Specificity } \\
\text { - Uncertainty } \\
\text { - Empathy } \\
\text { - Reliability } \\
\text { - Responsiveness } \\
\text { - Assurance } \\
\end{array}$ & $x$ & & & $x$ & $x$ & & $x$ & & $x$ & $\mathrm{x}$ & $x$ & $x$ & $x$ & $x$ \\
\hline $\begin{array}{l}\text { Douglas et } \\
\text { al. (2003) }\end{array}$ & $\begin{array}{l}\text { Website } \\
\text { Quality }\end{array}$ & \begin{tabular}{|l|} 
Websites of \\
Legal \\
Practices
\end{tabular} & \begin{tabular}{|l} 
- Presentation \\
- Content \\
- Accessibility \\
- Reliability \\
- Customer Support \\
- Security \\
\end{tabular} & $x$ & $x$ & $x$ & $x$ & & $x$ & & & $x$ & $x$ & $x$ & & & $\mathrm{x}$ \\
\hline $\begin{array}{l}\text { Evanschitzky } \\
\text { et al. (2004) }\end{array}$ & $\begin{array}{l}\text { E-Satis- } \\
\text { faction }\end{array}$ & $\begin{array}{l}\text { Online } \\
\text { Shopping }\end{array}$ & $\begin{array}{l}\text { - Convenience } \\
\text { - Product Offerings } \\
\text { - Product Information } \\
\text { - Site Design } \\
\text { - Financial Security } \\
\end{array}$ & $\mathrm{x}$ & $x$ & & & & $x$ & $x$ & & & $x$ & $\mathrm{x}$ & & $\mathrm{x}$ & $\mathrm{x}$ \\
\hline
\end{tabular}




\begin{tabular}{|c|c|c|c|c|c|c|c|c|c|c|c|c|c|c|c|c|c|}
\hline \multirow[b]{2}{*}{ Author(s) } & \multirow[b]{2}{*}{ Domain } & \multirow{2}{*}{$\begin{array}{c}\text { Scope of } \\
\text { Application }\end{array}$} & \multirow{2}{*}{$\begin{array}{l}\text { Dimensions + [Sub- } \\
\text { Dimensions] }\end{array}$} & \multicolumn{4}{|c|}{$\begin{array}{c}\text { Information } \\
\text { Attributes }\end{array}$} & \multicolumn{5}{|c|}{ Functional Attributes } & \multicolumn{5}{|c|}{ System Attributes } \\
\hline & & & & $A C C$ & com & REL & TIM & NER & AID & ALE & $A C Q$ & POP & AES & NAV & ADT & SPD & SEC \\
\hline $\begin{array}{l}\text { Fassnacht } \\
\text { and Koese } \\
(2006)\end{array}$ & $\begin{array}{l}\text { Quality of } \\
\text { Electronic } \\
\text { Service } \\
\text { (QES) - } \\
\text { Degree to } \\
\text { which an } \\
\text { electronic } \\
\text { service is } \\
\text { able to } \\
\text { efficiently } \\
\text { and } \\
\text { effectively } \\
\text { fulfill } \\
\text { relevant } \\
\text { customer } \\
\text { needs }\end{array}$ & $\begin{array}{l}\text { All forms of } \\
\text { Electronic } \\
\text { Services }\end{array}$ & $\begin{array}{l}\text { Environment Quality } \\
\text { [Graphic Quality, clarity of } \\
\text { layout] } \\
\text { - Delivery Quality [Attrac- } \\
\text { tiveness of selection, } \\
\text { information quality, ease of } \\
\text { use, technical quality] } \\
\text { - Outcome Quality [Reli- } \\
\text { ability, functional benefit, } \\
\text { emotional benefit] }\end{array}$ & $x$ & $x$ & $x$ & $x$ & $X$ & $x$ & & $x$ & & $x$ & $x$ & & $X$ & $x$ \\
\hline Gefen (2002) & $\begin{array}{l}\text { Service } \\
\text { Quality }\end{array}$ & $\begin{array}{l}\text { Online } \\
\text { Shopping }\end{array}$ & \begin{tabular}{|l} 
- Tangibles \\
- Reliability, \\
Responsiveness, \\
Assurance \\
- Empathy \\
\end{tabular} & & & & & & & & $x$ & $x$ & $x$ & & $x$ & & $x$ \\
\hline $\begin{array}{l}\text { Gounaris and } \\
\text { Dimitriadis } \\
\text { (2003) }\end{array}$ & $\begin{array}{l}\text { Service } \\
\text { Quality }\end{array}$ & Portal Sites & \begin{tabular}{|l} 
- Customer Care and Risk \\
Reduction Benefit \\
- Information Benefit \\
- Interaction Facilitation \\
Benefit
\end{tabular} & & & & & $x$ & & & $X$ & $X$ & & & & & $x$ \\
\hline $\begin{array}{l}\text { Gummerus et } \\
\text { al. (2004) }\end{array}$ & $\begin{array}{l}\text { Service } \\
\text { Quality }\end{array}$ & \begin{tabular}{|l} 
Content- \\
based \\
Websites
\end{tabular} & $\begin{array}{l}\text { - User Interface } \\
\text { - Responsiveness } \\
\text { - Need Fulfillment } \\
\text { - Security }\end{array}$ & & & & & $X$ & & & & & $X$ & $x$ & & & $x$ \\
\hline $\begin{array}{l}\text { Janda et al. } \\
(2002)\end{array}$ & $\begin{array}{l}\text { Internet } \\
\text { Retail } \\
\text { Service } \\
\text { Quality } \\
\text { (IRSQ) } \\
\end{array}$ & $\begin{array}{l}\text { Online } \\
\text { Shopping }\end{array}$ & \begin{tabular}{|l|} 
- Performance \\
- Access \\
- Security \\
- Sensation \\
- Information \\
\end{tabular} & $x$ & & & & & & & $X$ & & $x$ & & & & $\mathrm{x}$ \\
\hline $\begin{array}{l}\text { Jiang et al. } \\
(2002)\end{array}$ & $\begin{array}{l}\text { Informa- } \\
\text { tion } \\
\text { Systems } \\
\text { Quality } \\
\end{array}$ & $\begin{array}{l}\text { Information } \\
\text { Systems }\end{array}$ & \begin{tabular}{|l} 
- Reliability \\
- Responsiveness \\
- Assurance \\
- Empathy \\
\end{tabular} & & & & & & & & & $x$ & $x$ & & $x$ & & $x$ \\
\hline $\begin{array}{l}\text { Kettinger and } \\
\text { Lee (1997) }\end{array}$ & $\begin{array}{l}\text { Service } \\
\text { Quality }\end{array}$ & $\begin{array}{l}\text { Information } \\
\text { Systems }\end{array}$ & \begin{tabular}{|l|} 
- Tangibles \\
- Reliability \\
- Responsiveness \\
- Assurance \\
- Empathy \\
\end{tabular} & $x$ & & $X$ & $x$ & $x$ & & & $x$ & & & & & $x$ & $x$ \\
\hline $\begin{array}{l}\text { Kettinger and } \\
\text { Lee (2005) }\end{array}$ & $\begin{array}{l}\text { Zone of } \\
\text { Tolerance } \\
\text { Service } \\
\text { Quality }\end{array}$ & $\begin{array}{l}\text { Information } \\
\text { Systems }\end{array}$ & $\begin{array}{l}\text { - Reliability } \\
\text { - Responsiveness } \\
\text { - Rapport } \\
\text { - Tangibles }\end{array}$ & $X$ & $x$ & $x$ & $X$ & $X$ & & & $x$ & & $x$ & $x$ & $x$ & $x$ & \\
\hline $\begin{array}{l}\text { Kim and Lim } \\
(2001)\end{array}$ & $\begin{array}{l}\text { Website } \\
\text { Quality }\end{array}$ & $\begin{array}{l}\text { Online } \\
\text { Shopping }\end{array}$ & \begin{tabular}{|l|} 
- Entertainment \\
- Speed \\
- Information Quality \\
- Reliability
\end{tabular} & $x$ & $x$ & $x$ & $X$ & & & & & & $x$ & & & $X$ & \\
\hline $\begin{array}{l}\text { Kim and } \\
\text { Stoel (2004) }\end{array}$ & $\begin{array}{l}\text { Website } \\
\text { Quality }\end{array}$ & $\begin{array}{l}\text { Online } \\
\text { Shopping for } \\
\text { Apparel }\end{array}$ & $\begin{array}{l}\text { - Web Appearance } \\
\text { - Entertainment } \\
\text { - Information Fit-to-Task } \\
\text { - Transaction Capability } \\
\text { - Response Time } \\
\text { - Trust }\end{array}$ & & & $x$ & & & & & $x$ & & & $x$ & & $\mathrm{x}$ & $x$ \\
\hline
\end{tabular}




\begin{tabular}{|c|c|c|c|c|c|c|c|c|c|c|c|c|c|c|c|c|c|}
\hline \multirow[b]{2}{*}{ Author(s) } & \multirow[b]{2}{*}{ Domain } & \multirow{2}{*}{$\begin{array}{l}\text { Scope of } \\
\text { Application }\end{array}$} & \multirow{2}{*}{$\begin{array}{l}\text { Dimensions + [Sub- } \\
\text { Dimensions] }\end{array}$} & \multicolumn{4}{|c|}{$\begin{array}{l}\text { Information } \\
\text { Attributes }\end{array}$} & \multicolumn{5}{|c|}{ Functional Attributes } & \multicolumn{5}{|c|}{ System Attributes } \\
\hline & & & & $A C C$ & сом & REL & TIM & NER & AID & ALE & $A C Q$ & POP & AES & NAV & ADT & SPD & SEC \\
\hline $\begin{array}{l}\text { Kim et al. } \\
(2004)\end{array}$ & $\begin{array}{l}\text { Service } \\
\text { and } \\
\text { Website } \\
\text { Quality }\end{array}$ & $\begin{array}{l}\text { Online } \\
\text { Shopping }\end{array}$ & $\begin{array}{l}\text { - Service Quality [Reliability, } \\
\text { responsiveness, assurance, } \\
\text { and empathy] } \\
\text { - Website Quality [Informa- } \\
\text { tion quality and system } \\
\text { quality] }\end{array}$ & $X$ & & & & $X$ & $x$ & & $x$ & $x$ & $x$ & $x$ & $x$ & & $x$ \\
\hline $\begin{array}{l}\text { Kim et al. } \\
(2006)\end{array}$ & $\begin{array}{l}\text { Service } \\
\text { Quality }\end{array}$ & $\begin{array}{l}\text { Online } \\
\text { Shopping for } \\
\text { Apparel }\end{array}$ & $\begin{array}{l}\text { - Efficiency } \\
\text { - Fulfillment } \\
\text { - System Availability } \\
\text { - Privacy } \\
\text { - Responsiveness } \\
\text { - Contact } \\
\text { - Personalization } \\
\text { - Information } \\
\text { - Graphic Styles }\end{array}$ & $x$ & & & & $x$ & & & $x$ & $x$ & $x$ & $x$ & $x$ & $x$ & $x$ \\
\hline $\begin{array}{l}\text { Loiacono et } \\
\text { al. (2002) }\end{array}$ & \begin{tabular}{|l} 
Website \\
Quality \\
[WebQual]
\end{tabular} & $\begin{array}{l}\text { All manners } \\
\text { of Websites } \\
\text { but with no } \\
\text { explicit } \\
\text { reference to } \\
\text { service } \\
\text { delivery }\end{array}$ & $\begin{array}{l}\text { Usefulness [Information fit- } \\
\text { to-task, interactivity, trust, } \\
\text { response time] } \\
\text { - Ease of Use [Ease of } \\
\text { understanding, intuitive } \\
\text { operations] } \\
\text { - Entertainment [Visual } \\
\text { appeal, innovativeness, } \\
\text { flow] } \\
\text { - Complementary } \\
\text { Relationship [Consistent } \\
\text { image, online complete- } \\
\text { ness, better than alternative } \\
\text { channels] }\end{array}$ & & $x$ & $x$ & & $X$ & $x$ & $x$ & & & $x$ & $X$ & & $x$ & $x$ \\
\hline $\begin{array}{l}\text { Loiacono et } \\
\text { al. (2007) }\end{array}$ & $\begin{array}{l}\text { Website } \\
\text { Quality }\end{array}$ & Online Retail & \begin{tabular}{|l} 
- Information Fit-to-Task \\
- Tailored Information \\
- Trust \\
- Response Time \\
- Ease of Understanding \\
- Intuitive Operations \\
- Visual Appeal \\
- Innovativeness \\
- Emotional Appeal \\
- Consistent Image \\
- On-Line Completeness \\
- Relative Advantage
\end{tabular} & $x$ & $x$ & $x$ & & $x$ & & & $x$ & & $x$ & $x$ & $x$ & $x$ & $x$ \\
\hline $\begin{array}{l}\text { Luo et al. } \\
\text { (2012) }\end{array}$ & $\begin{array}{l}\text { Website } \\
\text { Quality }\end{array}$ & Online Retail & \begin{tabular}{|l|} 
- Customer Support \\
- Order Tracking \\
- On-time Delivery \\
- Product Met Expectation \\
- Product Availability \\
- Ease of Finding Product \\
- Site Design \\
- Clarity of Product Info \\
- Product Selection
\end{tabular} & $x$ & $x$ & $x$ & $x$ & $x$ & $x$ & & $x$ & $x$ & $x$ & $x$ & & & \\
\hline $\begin{array}{l}\text { McKinney et } \\
\text { al. (2002) }\end{array}$ & $\begin{array}{l}\text { Website } \\
\text { Quality }\end{array}$ & $\begin{array}{l}\text { Online } \\
\text { Shopping }\end{array}$ & \begin{tabular}{|l|} 
IQ Expectations [Rel- \\
evance, understandability, \\
reliability, adequacy, scope, \\
usefulness] \\
SQ Expectations [Access, \\
usability, entertainment, \\
hyperlinks, navigation, \\
interactivity]
\end{tabular} & $x$ & $x$ & $X$ & $x$ & & & & $x$ & & $x$ & $x$ & & & \\
\hline $\begin{array}{l}\text { Meliàn-Alzola } \\
\text { and Padron- } \\
\text { Robaina } \\
\text { (2006) }\end{array}$ & $\begin{array}{l}\text { Website } \\
\text { Quality }\end{array}$ & $\begin{array}{l}\text { Online } \\
\text { Shopping }\end{array}$ & $\begin{array}{l}\text { - Tangibility [Navigation, } \\
\text { signposting, tools, and } \\
\text { explanation] }\end{array}$ & & & & & $x$ & $x$ & & $x$ & & & $x$ & & & \\
\hline
\end{tabular}




\begin{tabular}{|c|c|c|c|c|c|c|c|c|c|c|c|c|c|c|c|c|c|}
\hline \multirow[b]{2}{*}{ Author(s) } & \multirow[b]{2}{*}{ Domain } & \multirow{2}{*}{$\begin{array}{l}\text { Scope of } \\
\text { Application }\end{array}$} & \multirow{2}{*}{$\begin{array}{l}\text { Dimensions + [Sub- } \\
\text { Dimensions] }\end{array}$} & \multicolumn{4}{|c|}{$\begin{array}{l}\text { Information } \\
\text { Attributes }\end{array}$} & \multicolumn{5}{|c|}{ Functional Attributes } & \multicolumn{5}{|c|}{ System Attributes } \\
\hline & & & & ACC & com & REL & TIM & NER & AID & ALE & $A C Q$ & POP & AES & NAV & ADT & SPD & SEC \\
\hline $\begin{array}{l}\text { Nath and } \\
\text { Singh (2010) }\end{array}$ & $\begin{array}{l}\text { Website } \\
\text { Quality }\end{array}$ & \begin{tabular}{|l|} 
Web Service \\
Electronic \\
Marketplace
\end{tabular} & $\begin{array}{l}\text { - Availability } \\
\text { - Accessibility } \\
\text { - Throughput } \\
\text { - Latency } \\
\text { - Environment Quality } \\
\text { - Information Quality }\end{array}$ & $x$ & $x$ & & $x$ & & & & $x$ & & $x$ & $x$ & $x$ & $\mathrm{x}$ & \\
\hline $\begin{array}{l}\text { O'Neill et al. } \\
(2001)\end{array}$ & $\begin{array}{l}\text { Service } \\
\text { Quality }\end{array}$ & \begin{tabular}{|l} 
Online \\
Service \\
Websites
\end{tabular} & $\begin{array}{l}\text { Contact [Assurance, } \\
\text { empathy + (reliability)] } \\
\text { - Responsiveness } \\
\text { - Reliability } \\
\text { - Tangibles } \\
\end{array}$ & & & & & & & & & $x$ & $x$ & $x$ & $x$ & $x$ & $x$ \\
\hline $\begin{array}{l}\text { Oh and Teo } \\
(2010)\end{array}$ & $\begin{array}{l}\text { Service } \\
\text { Quality }\end{array}$ & Online Retail & $\begin{array}{l}\text { - Information Quality } \\
\text { - Service Convenience }\end{array}$ & $x$ & $x$ & & & $x$ & & & $x$ & $x$ & $x$ & & & $x$ & \\
\hline $\begin{array}{l}\text { Palmer } \\
(2002)\end{array}$ & \begin{tabular}{|l|} 
Website \\
Quality
\end{tabular} & $\begin{array}{l}\text { Online } \\
\text { Shopping }\end{array}$ & $\begin{array}{l}\text { - Download Delay [Initial } \\
\text { access speed, speed of } \\
\text { display between pages] } \\
\text { - Navigation/Organization } \\
\text { [Arrangement, sequence, } \\
\text { links, layout] } \\
\text { - Interactivity [Customiza- } \\
\text { tion, interactivity] } \\
\text { - Responsiveness } \\
\text { [Feedback, FAQ] } \\
\text { - Information/Content } \\
\text { [Amount of information, } \\
\text { variety of information, word } \\
\text { count, content quality] }\end{array}$ & $\mathrm{x}$ & $x$ & & & $x$ & & & & $\mathrm{x}$ & $x$ & $x$ & $x$ & $\mathrm{x}$ & \\
\hline $\begin{array}{l}\text { Parasuraman } \\
\text { et al. (2005) }\end{array}$ & $\begin{array}{l}\text { Service } \\
\text { Quality } \\
\text { [E-S- } \\
\text { QUAL] } \\
\end{array}$ & $\begin{array}{l}\text { Online } \\
\text { Shopping }\end{array}$ & \begin{tabular}{|l|} 
- Efficiency \\
- System Availability \\
- Fulfillment \\
- Privacy \\
\end{tabular} & & & & & & & & $x$ & & $x$ & & & $x$ & $x$ \\
\hline $\begin{array}{l}\text { Petter et al. } \\
(2013)\end{array}$ & $\begin{array}{l}\text { Informa- } \\
\text { tion } \\
\text { Systems } \\
\text { Quality }\end{array}$ & $\begin{array}{l}\text { Information } \\
\text { Systems }\end{array}$ & $\begin{array}{l}\text { System Quality [Ease of } \\
\text { use, system flexibility, } \\
\text { system reliability, ease of } \\
\text { learning, intuitiveness, } \\
\text { sophistication, flexibility, } \\
\text { response time] } \\
\text { - Information Quality [Rele- } \\
\text { vance, understandability, } \\
\text { accuracy, conciseness, } \\
\text { completeness, currency, } \\
\text { timeliness, usability] } \\
\text { Service Quality } \\
\text { [Responsiveness, accuracy, } \\
\text { reliability, technical compe- } \\
\text { tence, empathy of the } \\
\text { personnel staff] }\end{array}$ & $x$ & $x$ & $x$ & $x$ & & & & & $x$ & $x$ & $x$ & $x$ & $x$ & $x$ \\
\hline $\begin{array}{l}\text { Pitt et al. } \\
\text { (1995) }\end{array}$ & $\begin{array}{l}\text { Service } \\
\text { Quality }\end{array}$ & $\begin{array}{l}\text { Information } \\
\text { Systems }\end{array}$ & $\begin{array}{l}\text { - Tangibles } \\
\text { - Reliability } \\
\text { - Responsiveness } \\
\text { - Assurance } \\
\text { - Empathy }\end{array}$ & $x$ & & $x$ & $x$ & $x$ & & & $x$ & & & & & $x$ & $x$ \\
\hline $\begin{array}{l}\text { Pitt et al. } \\
\text { (1997) }\end{array}$ & $\begin{array}{l}\text { Service } \\
\text { Quality }\end{array}$ & $\begin{array}{l}\text { Information } \\
\text { Systems }\end{array}$ & $\begin{array}{l}\text { - Tangibles } \\
\text { - Reliability } \\
\text { - Responsiveness } \\
\text { - Assurance } \\
\text { - Empathy }\end{array}$ & $x$ & & $x$ & $\mathrm{x}$ & $x$ & & & $\mathrm{x}$ & & & & & $x$ & $x$ \\
\hline $\begin{array}{l}\text { Ribbink et al. } \\
(2004)\end{array}$ & $\begin{array}{l}\text { Service } \\
\text { Quality }\end{array}$ & $\begin{array}{l}\text { Online } \\
\text { Shopping }\end{array}$ & \begin{tabular}{|l|} 
- Ease of Use \\
- Website Design \\
- Customization \\
- Responsiveness \\
- Assurance
\end{tabular} & & & & & $x$ & & & & & $x$ & $x$ & $x$ & & $x$ \\
\hline
\end{tabular}




\begin{tabular}{|c|c|c|c|c|c|c|c|c|c|c|c|c|c|c|c|c|c|}
\hline \multirow[b]{2}{*}{ Author(s) } & \multirow[b]{2}{*}{ Domain } & \multirow{2}{*}{$\begin{array}{l}\text { Scope of } \\
\text { Application }\end{array}$} & \multirow{2}{*}{$\begin{array}{l}\text { Dimensions + [Sub- } \\
\text { Dimensions] }\end{array}$} & \multicolumn{4}{|c|}{$\begin{array}{l}\text { Information } \\
\text { Attributes }\end{array}$} & \multicolumn{5}{|c|}{ Functional Attributes } & \multicolumn{5}{|c|}{ System Attributes } \\
\hline & & & & $A C C$ & Com & REL & TIM & NER & AID & ALE & $A C Q$ & POP & AES & NAV & ADT & SPD & SEC \\
\hline $\begin{array}{l}\text { Rosen and } \\
\text { Purinton } \\
(2004)\end{array}$ & \begin{tabular}{|l|} 
Website \\
Quality \\
[Website \\
Preference \\
Scale \\
(WSPS)] \\
\end{tabular} & $\begin{array}{l}\text { Online } \\
\text { Shopping }\end{array}$ & \begin{tabular}{|l|} 
- Coherence \\
- Complexity \\
- Legibility \\
- Mystery
\end{tabular} & & & & & & & $x$ & & & $x$ & $x$ & & & \\
\hline $\begin{array}{l}\text { Santos } \\
(2003)\end{array}$ & $\begin{array}{l}\text { Service } \\
\text { Quality }\end{array}$ & $\begin{array}{l}\text { Online } \\
\text { Shopping }\end{array}$ & \begin{tabular}{|l|} 
Incubative Dimension \\
[Likely to increase website's \\
daily hit rates; ease of use, \\
appearance, linkage, struc- \\
ture and layout, and \\
content] \\
- Active Dimension [Likely \\
to increase customer \\
retention and positive word \\
of mouth referral; reliability, \\
efficiency, support, \\
communications, security, \\
and incentives]
\end{tabular} & & $x$ & & & $x$ & & & & $x$ & $x$ & $x$ & & $x$ & $x$ \\
\hline $\begin{array}{l}\text { Schubert } \\
(2002)\end{array}$ & \begin{tabular}{|l|} 
Website \\
Quality \\
[Extended \\
Web \\
Assess- \\
ment \\
Method \\
(EWAN)] \\
\end{tabular} & $\begin{array}{l}\text { Online } \\
\text { Shopping }\end{array}$ & $\begin{array}{l}\text { - Ease of Use Criteria } \\
\text { - Usefulness Criteria } \\
\text { - Trust Criteria }\end{array}$ & & & $x$ & & & & & & & $x$ & & & & $x$ \\
\hline $\begin{array}{l}\text { Semeijn et al. } \\
(2005)\end{array}$ & $\begin{array}{l}\text { Service } \\
\text { Quality }\end{array}$ & $\begin{array}{l}\text { Online } \\
\text { Shopping }\end{array}$ & $\begin{array}{l}\text { - Assurance } \\
\text { - Navigation } \\
\text { - E-Scape } \\
\text { - Accuracy } \\
\text { - Responsiveness } \\
\text { - Customization } \\
\end{array}$ & $x$ & & & & $x$ & & & & & & $x$ & $x$ & & $x$ \\
\hline $\begin{array}{l}\text { Shchiglik and } \\
\text { Barnes } \\
(2004)\end{array}$ & \begin{tabular}{|l|} 
Website \\
Quality \\
[Perceived \\
Airline \\
Website \\
Quality \\
Instrument \\
(PAWQI)]
\end{tabular} & $\begin{array}{l}\text { Online } \\
\text { Shopping }\end{array}$ & $\begin{array}{l}\text { - Domain Specific } \\
\text { Dimension } \\
\text { - Web Information Quality } \\
\text { - Web Interaction Quality } \\
\text { - Web Design Quality }\end{array}$ & $x$ & $x$ & $X$ & & & $X$ & & $x$ & $x$ & $x$ & $x$ & & & \\
\hline $\begin{array}{l}\text { Shim et al. } \\
(2002)\end{array}$ & $\begin{array}{l}\text { Website } \\
\text { Quality }\end{array}$ & $\begin{array}{l}\text { Online } \\
\text { Shopping }\end{array}$ & $\begin{array}{ll}\text { - Ease of Contact } \\
\text { - Customer Service } \\
\text { Information } \\
\text { - Ease of Access of } \\
\text { Product Information }\end{array}$ & $x$ & & & & & $X$ & $x$ & & $x$ & $x$ & & & & \\
\hline Singh (2002) & E-Services & \begin{tabular}{|l} 
Online \\
Service \\
Websites
\end{tabular} & \begin{tabular}{|l} 
E-Search \\
- E-Response \\
- E-Transaction and \\
E-Payment \\
- E-Assurance and Trust \\
- E-Help and \\
E-Technologies
\end{tabular} & & & & & & $x$ & & $x$ & $x$ & $x$ & & & & $x$ \\
\hline $\begin{array}{l}\text { Srinivasan et } \\
\text { al. (2002) }\end{array}$ & $\begin{array}{l}\text { E-Service } \\
\text { Loyalty }\end{array}$ & $\begin{array}{l}\text { Online } \\
\text { Shopping }\end{array}$ & \begin{tabular}{|l|} 
- Customization \\
- Contact Interactivity \\
- Care \\
- Community \\
- Convenience \\
- Cultivation \\
- Choice \\
- Character of E-Retailer \\
\end{tabular} & & & & & $x$ & & $x$ & & $x$ & $x$ & & $x$ & & $x$ \\
\hline
\end{tabular}




\begin{tabular}{|c|c|c|c|c|c|c|c|c|c|c|c|c|c|c|c|c|c|}
\hline \multirow[b]{2}{*}{ Author(s) } & \multirow[b]{2}{*}{ Domain } & \multirow{2}{*}{$\begin{array}{l}\text { Scope of } \\
\text { Application }\end{array}$} & \multirow{2}{*}{$\begin{array}{c}\text { Dimensions + [Sub- } \\
\text { Dimensions] }\end{array}$} & \multicolumn{4}{|c|}{$\begin{array}{l}\text { Information } \\
\text { Attributes }\end{array}$} & \multicolumn{5}{|c|}{ Functional Attributes } & \multicolumn{5}{|c|}{ System Attributes } \\
\hline & & & & ACC & сом & REL & TIM & NER & AID & ALE & $A C Q$ & POP & AES & NAV & ADT & SPD & SEC \\
\hline $\begin{array}{l}\text { Surjadjaja et } \\
\text { al. (2003) }\end{array}$ & $\begin{array}{l}\text { Service } \\
\text { Quality }\end{array}$ & $\begin{array}{l}\text { Online } \\
\text { Service } \\
\text { Websites }\end{array}$ & $\begin{array}{l}\text { - Service Marketing } \\
\text { [Trusted services, internal } \\
\text { communication, external } \\
\text { communication, price, and } \\
\text { return process] } \\
\text { - Service Delivery [Real time } \\
\text { assistance by CSR, fulfill- } \\
\text { ment, and availability] } \\
\text { - Service Design [Respon- } \\
\text { siveness, site effectiveness } \\
\text { \& functionality, up to date } \\
\text { information, supply chain } \\
\text { information, system } \\
\text { integration, personalization, } \\
\text { customization, navigability, } \\
\text { security, interactivity, } \\
\text { service recovery] }\end{array}$ & $\mathrm{x}$ & & & $x$ & $x$ & & & $x$ & $x$ & $x$ & $x$ & $x$ & $x$ & $x$ \\
\hline $\begin{array}{l}\text { Tan et al. } \\
(2013)\end{array}$ & $\begin{array}{l}\text { Service } \\
\text { Quality }\end{array}$ & $\begin{array}{l}\text { Electronic } \\
\text { Government } \\
\text { Services }\end{array}$ & $\begin{array}{l}\text { - Requirements [Needing, } \\
\text { customizing] } \\
\text { - Acquisition [Sourcing, } \\
\text { trying, ordering, paying, } \\
\text { tracking, accepting, } \\
\text { authorizing] } \\
\text { - Ownership [Training, } \\
\text { monitoring, upgrading, } \\
\text { scheduling, delegating, } \\
\text { negotiating, evaluating] } \\
\text { - Accessibility } \\
\text { - Navigability } \\
\text { - Interactivity } \\
\text { - Interoperability } \\
\text { - Adaptability } \\
\text { - Security }\end{array}$ & & & & & $x$ & $\mathrm{x}$ & $x$ & $x$ & $x$ & $x$ & $x$ & $x$ & $x$ & $\mathrm{x}$ \\
\hline $\begin{array}{l}\text { Tate and } \\
\text { Evermann } \\
(2010)\end{array}$ & $\begin{array}{l}\text { Service } \\
\text { Quality }\end{array}$ & $\begin{array}{l}\text { Information } \\
\text { Systems }\end{array}$ & \begin{tabular}{|l|} 
- Tangibles \\
- Reliability \\
- Responsiveness \\
- Assurance \\
- Empathy \\
\end{tabular} & $x$ & & $x$ & $x$ & $x$ & & & $x$ & $x$ & $x$ & & $x$ & $x$ & $x$ \\
\hline $\begin{array}{l}\text { Teo et al. } \\
(2008)\end{array}$ & \begin{tabular}{|l} 
Website \\
Quality
\end{tabular} & \begin{tabular}{|l} 
Electronic \\
Government \\
Services
\end{tabular} & \begin{tabular}{|l|} 
- Information Quality \\
- System Quality \\
- Service Quality
\end{tabular} & $x$ & $\mathrm{X}$ & $x$ & $x$ & $\mathrm{x}$ & & & & & $\mathrm{x}$ & $x$ & & $\mathrm{x}$ & \\
\hline $\begin{array}{l}\text { Van Dyke et } \\
\text { al. (1997) }\end{array}$ & $\begin{array}{l}\text { Service } \\
\text { Quality }\end{array}$ & $\begin{array}{l}\text { Information } \\
\text { Systems }\end{array}$ & $\begin{array}{l}\text { - Tangibles } \\
\text { - Reliability } \\
\text { - Responsiveness } \\
\text { - Assurance } \\
\text { - Empathy } \\
\end{array}$ & $x$ & & $x$ & $x$ & $x$ & & & $\mathrm{x}$ & & & & & $x$ & $x$ \\
\hline Wang (2008) & $\begin{array}{l}\text { Website } \\
\text { Quality }\end{array}$ & \begin{tabular}{|l} 
Online \\
Shopping
\end{tabular} & $\begin{array}{l}\text { - Information Quality } \\
\text { - System Quality } \\
\text { - Service Quality }\end{array}$ & $x$ & $\mathrm{X}$ & $x$ & $x$ & $\mathrm{x}$ & & & & $x$ & $x$ & $x$ & & & $\mathrm{x}$ \\
\hline $\begin{array}{l}\text { Watson et al. } \\
\text { (1998) }\end{array}$ & $\begin{array}{l}\text { Service } \\
\text { Quality }\end{array}$ & $\begin{array}{l}\text { Information } \\
\text { Systems }\end{array}$ & \begin{tabular}{|l|} 
- Tangibles \\
- Reliability \\
- Responsiveness \\
- Assurance \\
\end{tabular} & $x$ & & $x$ & $x$ & $x$ & & & $x$ & & & & & $x$ & $\mathrm{x}$ \\
\hline $\begin{array}{l}\text { Wolfinbarger } \\
\text { and Gilly } \\
(2003)\end{array}$ & $\begin{array}{l}\text { Service } \\
\text { Quality } \\
\text { [eTailQ] }\end{array}$ & $\begin{array}{l}\text { Online } \\
\text { Shopping }\end{array}$ & $\begin{array}{l}\text { - Website Design } \\
\text { - Fulfillment/Reliability } \\
\text { - Security/Privacy } \\
\text { - Customer Service }\end{array}$ & & & & & & & & $\mathrm{x}$ & $x$ & $\mathrm{X}$ & $x$ & & & $x$ \\
\hline
\end{tabular}




\begin{tabular}{|c|c|c|c|c|c|c|c|c|c|c|c|c|c|c|c|c|c|}
\hline \multirow[b]{2}{*}{ Author(s) } & \multirow[b]{2}{*}{ Domain } & \multirow{2}{*}{$\begin{array}{c}\text { Scope of } \\
\text { Application }\end{array}$} & \multirow{2}{*}{$\begin{array}{l}\text { Dimensions + [Sub- } \\
\text { Dimensions] }\end{array}$} & \multicolumn{4}{|c|}{$\begin{array}{l}\text { Information } \\
\text { Attributes }\end{array}$} & \multicolumn{5}{|c|}{ Functional Attributes } & \multicolumn{5}{|c|}{ System Attributes } \\
\hline & & & & $A C C$ & com & REL & TIM & NER & AID & ALE & $A C Q$ & POP & AES & NAV & ADT & SPD & SEC \\
\hline $\begin{array}{l}\text { Xu et al. } \\
\text { (2013) }\end{array}$ & $\begin{array}{l}\text { Service } \\
\text { Quality }\end{array}$ & \begin{tabular}{|l|} 
Electronic \\
Services
\end{tabular} & $\begin{array}{l}\text { Information Quality } \\
\text { [Completeness, accuracy, } \\
\text { format, currency] } \\
\text { - System Quality [Reliability, } \\
\text { flexibility, accessibility, } \\
\text { timeliness] } \\
\text { - Service Quality [Tangibles, } \\
\text { responsiveness, empathy, } \\
\text { service reliability, } \\
\text { assurance] }\end{array}$ & $x$ & $x$ & $x$ & $\mathrm{x}$ & & & & & & $x$ & $\mathrm{x}$ & $x$ & $x$ & $x$ \\
\hline $\begin{array}{l}\text { Zeithaml } \\
(2002) \\
\text { Zeithaml et } \\
\text { al. (2002) }\end{array}$ & $\begin{array}{l}\text { Service } \\
\text { Quality } \\
\text { [e-SQ] }\end{array}$ & $\begin{array}{l}\text { Online } \\
\text { Shopping }\end{array}$ & $\begin{array}{l}\text { - Information Availability } \\
\text { and Content } \\
\text { - Ease of Use or Usability } \\
\text { - Privacy/Security } \\
\text { - Graphic Style } \\
\text { - Fulfillment }\end{array}$ & & $x$ & & $x$ & & & & $x$ & & $x$ & $x$ & & & $\mathrm{x}$ \\
\hline $\begin{array}{l}\text { Zhang et al. } \\
\text { (2001) }\end{array}$ & $\begin{array}{l}\text { Website } \\
\text { Quality }\end{array}$ & \begin{tabular}{|l} 
News \\
Content- \\
based \\
Website
\end{tabular} & $\begin{array}{l}\text { Basic [Features the sup- } \\
\text { port expected needs of } \\
\text { users] } \\
\text { - Performance [Features } \\
\text { that enable the website to } \\
\text { stay current to users' } \\
\text { expectations] } \\
\text { - Exciting [Features that are } \\
\text { not expected but have the } \\
\text { ability to excite and delight } \\
\text { users] }\end{array}$ & & & $x$ & $x$ & $x$ & $\mathrm{x}$ & & $x$ & & & & & & \\
\hline
\end{tabular}

ACC - Accuracy; COM - Completeness; REL - Relevance; TIM - Timely; NER - Needs Recognition; AID - Alternatives Identification; ALE - Alternatives Evaluation; ACQ - Acquisition; POP - Post-Purchase; AES - Accessibility; NAV - Navigability; ADT - Adaptability; SPD - Speed; SEC - Security

\section{Appendix B References}

Agarwal, R., and Venkatesh, V. 2002. "Assessing a Firm's Web Presence: A Heuristic Evaluation Procedure for Measurement of Usability," Information Systems Research (13:20), pp. 168-186.

Barber, R. E., and Lucas, H. C. 1983. "System Response Time, Operator Productivity, and Job Satisfaction," Communication of the ACM (26:11), pp. 972-986.

Benlian, A., Koufaris, M., and Hess, T. 2011. "Service Quality in Software-as-a-Service: Developing the SaaS-Qual Measure and Examining its Role in Usage Continuance," Journal of Management Information Systems (28:3), pp. 85-126.

Cai, S., and Jun, M. 2003. "Internet Users' Perceptions of Online Service Quality: A Comparison of Online Buyers and Information Searchers," Managing Service Quality (13:6), pp. 504-519.

Cenfetelli, R. T., Benbasat, I., and Al-Natour, S. 2008. "Addressing the What and How of Online Services: Positioning Supporting-Services Functionality and Service Quality for Business to Consumer Success," Information Systems Research (19:2), pp. 161-181.

Childers, T. L., Carr, C. L., Peck, J., and Carson, S. 2001. "Hedonic and Utilitarian Motivations for Online Retail Shopping Behavior,” Journal of Retailing (77:4), pp. 511-535.

Chiu, C-M., Chiu, C-S., and Chang, H-C. 2007. "Examining the Integrated Influence of Fairness and Quality on Learners' Satisfaction and Web-Based Learning Continuance Intention," Information Systems Journal (17:3), pp. 271-287.

Collier, J. E., and Bienstock, C. C. 2003. “A Conceptual Framework for Measuring E-Service Quality,” in Developments in Marketing Science, Academy of Marketing Science Conference Proceedings, H. Spotts, (ed.), Academy of Marketing Science, Corel Gables, FL, pp. 158-162.

Collier, J. E., and Bienstock, C. C. 2006. "Measuring Service Quality in E-Retailing," Journal of Service Research (8:3), pp. $260-275$.

Connolly, R., Bannister, F., and Kearney, A. 2010. “Government Website Service Quality: A Study of the Irish Revenue Online Service," European Journal of Information Systems (19:4), pp. 649-667.

DeLone, W. H., and McLean, E. R. 1992. "Information Systems Success: The Quest for the Dependent Variable," Information Systems Research (3:1), pp. 60-95.

DeLone, W. H., and McLean, E. R. 2003. "The DeLone and McLean Model of Information Systems Success: A Ten-Year Update,” Journal of Management Information Systems (19:4), pp. 9-30. 
Delone, W. H., and McLean, E. R. 2004. "Measuring E-Commerce Success: Applying the DeLone \& McLean Information Systems Success Model," International Journal of Electronic Commerce (9:1), pp. 31-47.

Devaraj, S., Fan, M. and Kohli, R. 2002. "Antecedents of B2C Channel Satisfaction and Preference: Validating E-Commerce Metrics," Information Systems Research (13:3), pp. 316-333.

Douglas, A., Muir, L., and Meehan, K. 2003. "E-Quality in the E-Services Provision of Legal Practices," Management Service Quality (13:6), pp. 483-491.

Evanschitzky, H., Iyer, G. R., Hesse, J., and Ahlert, D. 2004. "E-Satisfaction: A Re-Examination,” Journal of Retailing (80), pp. $239-247$.

Fassnacht, M., and Koese, I. 2006. "Quality of Electronic Services: Conceptualizing and Testing a Hierarchical Model," Journal of Service Research (9:1), pp. 19-37.

Gefen, D. 2002. "Customer Loyalty in e-Commerce," Journal of the Association for Information Systems (3:1), pp. 27-51.

Gounaris, S., and Dimitriadis S. 2003. "Assessing Service Quality on the Web: Evidence from Business-to-Consumer Portals," Journal of Services Marketing (17:5), pp. 529-548.

Gummerus, J., Liljander, V., Pura, M., and van Riel, A. 2004. "Customer Loyalty to Content-Based Websites: The Case of an Online HealthCare Service," Journal of Service Marketing (18:3), pp. 175-186.

Janda, S., Trocchia, P. J., and Gwinner, K. P. 2002. “Consumer Perceptions of Internet Retail Service Quality," International Journal of Service Industry Management (13:5), pp. 412-431.

Jiang, J. J., Klein, G., and Carr, C. L. 2002. "Measuring Information System Service Quality: SERVQUAL from the Other Side," MIS Quarterly (26:2), pp. 145-166.

Kettinger, W. J., and Lee, C. C. 1997. "Pragmatic Perspectives on the Measurement of Information Systems Service Quality," MIS Quarterly (21:2), pp. 223-240.

Kettinger, W. J., and Lee, C. C. 2005. “Zones of Tolerance: Alternative Scales for Measuring Information Systems Service Quality,” MIS Quarterly (29:4), pp. 607-623.

Kim, H-W., Xu, Y., and Koh, J. 2004. "A Comparison of Online Trust Building Factors Between Potential Customers and Repeat Customers," Journal of the Association for Information Systems (5:10), pp. 392-420.

Kim, M., Kim J-H., and Lennon, S. J. 2006. “Online Service Attributes Available on Apparel Retail Websites: An E-S-QUAL Approach,” Managing Service Quality (16:1), pp. 51-77.

Kim, S. Y., and Lim, Y. J. 2001. “Consumers' Perceived Importance of and Satisfaction with Internet Shopping,” Electronic Marketing (11:3), pp. 148-154.

Kim, S., and Stoel, L. 2004. “Apparel Retailers: Website Quality Dimensions and Satisfaction,” Journal of Retailing and Consumer Services (11), pp. 109-117.

Loiacono, E. T., Watson, R. T., and Goodhue, D. L. 2002. "WEBQUAL: A Measure of Website Quality,” in Proceedings of 2002 Marketing Theory and Applications, Chicago, IL, pp. 432-438.

Loiacono, E. T., Watson, R. T., and Goodhue, D. L. 2007. “WebQual: An Instrument for Consumer Evaluation of Web Sites,” International Journal of Electronic Commerce (11:3), pp. 51-87.

Luo J., Ba, S., and Zhang, H. 2012. "The Effectiveness of Online Shopping Characteristics and Well-Designed Websites on Satisfaction," MIS Quarterly (36:4), pp. 1131-1144.

McKinney, V., Yoon, K., and Zahedi, F. 2002. "The Measurement of Web-Customer Satisfaction: An Expectation and Disconfirmation Approach," Information Systems Research (13:3), pp. 296-315.

Melian-Alzola, L., and Padron-Robaina, V. 2006. "Tangibility as a Quality Factor in Electronic Commerce B2C," Managing Service Quality (16:3), pp. 320-338.

Nath, A. K., and Singh, R. 2010. "Evaluating the Performance and Quality of Web Services in Electronic Marketplaces," e-Service Journal (7:1), pp. 43-59.

O’Neill, M., Wright, C., and Fitz, F. 2001. "Quality Evaluation in Online Service Environments: An Application of the Importance-Performance Measurement Technique," Managing Service Quality (11:6), pp. 402-417.

Oh, L-B., and Teo, H-H. 2010. “Consumer Value Co-creation in a Hybrid Commerce Service-Delivery System," International Journal of Electronic Commerce (14:3), pp. 35-62.

Palmer, J. W. 2002. "Web Site Usability, Design and Performance Metrics," Information Systems Research (13:2), pp. $151-167$.

Parasuraman, A., Zeithaml, V. A., and Malhotra, A. 2005. "E-S-Qual: A Multiple-Item Scale for Assessing Electronic Service Quality," Journal of Service Research (7:3), pp. 213-233.

Petter, S., Delone, W., and McLean E. R. 2013. "Information Systems Success: The Quest for the Independent Variables," Journal of Management Information Systems (29:4), pp. 7-61.

Pitt, L. F., Watson, R. T., and Kavan, B. 1995. “A Measure of Information Systems Effectiveness,” MIS Quarterly (19:2), pp. 173-187.

Pitt, L. F., Watson, R. T., and Kavan, C. B. 1997. "Measuring Information Systems Service Quality: Concerns for a Complete Canvas,” MIS Quarterly (21:2), pp. 209-221.

Ribbink, D., van Riel, A. C. R., Liljander, V., and Streukens, S. 2004. "Comfort Your Online Customer: Quality, Trust, and Loyalty on the Internet," Managing Service Quality (14:6), pp. 446-456. 
Rosen, D. E., and Purinton, E. 2004. "Website Design: Viewing the Web as a Cognitive Landscape,” Journal of Business Research (57:7), pp. 787-794.

Santos, J. 2003. "E-Service Quality: A Model of Virtual Service Quality Dimensions,” Management Service Quality (13:3), pp. 233-246.

Schubert, P. 2002. "Extended Web Assessment Method (EWAM): Evaluation of Electronic Commerce Applications from the Customer's Viewpoint," International Journal of Electronic Commerce (7:2), pp. 51-80.

Semeijn, J., van Riel, A. C. R., van Birgelen, M. J. H., and Streukens, S. 2005. "E-Services and Offline Fulfillment: How E-Loyalty is Created," Managing Service Quality (15:2), pp. 182-194.

Shchiglik, C., and Barnes, S. J. 2004. "Evaluating Website Quality in the Airline Industry," Journal of Computer Information Systems (44:3), pp. 17-25.

Shim, J. P., Shin, Y. B., and Nottingham, L. 2002. "Retailer Web Site Influence on Customer Shopping: An Exploratory Study on Key Factors of Customer Satisfaction," Journal of the Association for Information Systems (3:1), pp. 53-76.

Singh, M. 2002. "E-Services and their Role in B2C E-Commerce," Managing Service Quality (12:6), pp. 434-446.

Srinivasan, S. S., Anderson, R., and Ponnavolu, K. 2002. "Customer Loyalty in E-Commerce: An Exploration of its Antecedents and Consequences," Journal of Retailing (78:1), pp. 41-50.

Surjadjaja, H., Ghosh, S., and Antony, J. 2003. "Determining and Assessing the Determinants of E-Service Operations," Managing Service Quality (13:1), pp. 39-53.

Tan, C. W., Benbasat, I., and Cenfetelli, R. 2013. "IT-Mediated Customer Service Content and Delivery in Electronic Governments: An Empirical Investigation of the Antecedents of Service Quality," MIS Quarterly (37:1), pp. 77-109.

Tate, M., and Evermann, J. 2010. “The End of ServQual in Online Services Research: Where to From Here," e-Service Journal (7:1), pp. 60-85.

Teo, T. S. H., Srivastava, S. C., and Jiang, L. 2008. "Trust and Electronic Government Success: An Empirical Study," Journal of Management Information Systems (25:3), pp. 99-131.

Van Dyke, T. P., Kappelman, L. A., and Prybutok, V. R. 1997. "Measuring Information Systems Service Quality: Concerns on the Use of the SERVQUAL Questionnaire," MIS Quarterly (21:2), pp. 195-208.

Wang, Y-S. 2008. "Assessing E-Commerce Systems Success: A Respecification and Validation of the DeLone and McLean Model of IS Success," Information Systems Journal (18), pp. 529-557.

Watson, R. T., Pitt, L. F., and Kavan, C. B. 1998. "Measuring Information Systems Service Quality: Lessons from Two Longitudinal Case Studies," MIS Quarterly (22:1), pp. 61-79.

Wolfinbarger, M., and Gilly, M. C. 2003. “eTailQ: Dimensionalizing, Measuring and Predicting etail Quality,” Journal of Retailing (79:3), pp. 183-198.

Xu, D., Benbasat, I., and Cenfetelli, R. 2013. "Integrating Service Quality with System and Information Quality: An Empirical Test in the E-Service Context," MIS Quarterly (37:1), pp. 777-794.

Zeithaml, V. A. 2002. "Service Excellence in Electronic Channels," Managing Service Quality (12:3), pp. 135-138.

Zeithaml, V. A., Parasuraman, A., and Malhotra, A. 2002. "Service Quality Delivery through Web Sites: A Critical Review of Extant Knowledge," Journal of the Academy of Marketing Science (30:4), pp. 362-375.

Zhang, P., von Dran, G. M., Blake, P., and Pipithsuksunt, V. 2001. "Important Design Features in Different Web Site Domains: An Empirical Study of User Perceptions," e-Service Journal (1:1), pp. 77-91. 


\section{Appendix C}

\section{Questionnaire Development and Survey Protocol}

Because respondents having prior experiences with e-commerce service failures are likely to be Internet-savvy, we decided to elicit failure incidents via an online survey (Boyer et al. 2002; Stanton and Rogelberg 2001). A qualitative electronic survey questionnaire was carefully crafted for data collection. The questionnaire began with a statement on the purpose of the study and the characteristics of respondents we were recruiting.

This research is an online questionnaire to aid us in understanding the different types of negative experiences with e-services (i.e., online service failures) that confront consumers when performing online transactions. Online service failures are problems you experienced with an e-commerce website that prevent you from achieving your purpose for visiting the website in the first place. A more detailed description of what constitutes online service failures will be provided on the next page.

To participate in this study, you must have, at the very least, conducted online transactions via websites and experienced online service failures before. The results from this questionnaire will be utilized in subsequent tests to understand how various technological tools can alleviate these negative service experiences and improve upon the design of websites for consumers.

Study procedures were also outlined to give potential respondents an idea of what to expect from the questionnaire.

If you agree to participate in this study, you will first be asked several questions to determine your level of experience with online transactions and online service failures. You will then be presented with a series of open-ended questions relating to your experiences with online service failures when transacting via e-commerce websites.

You will be expected to recall THREE separate instances of online service failures in answering the open-ended questions. For each open-ended question, a text box will be provided for you to input comments and opinions pertaining to certain aspects of your online website experiences. Please be as detailed as possible in describing these experiences.

We anticipate that completing these tasks will require about 25 to 30 minutes of your time.

Respondents who consented to participating in the survey were presented with our definition of e-commerce service failure and some common examples. This was done not only to familiarize respondents with the phenomenon of interest, but also to ensure proper alignment between conceptualization and operationalization. Additionally, the choice of words like necessary and essential aid in anchoring respondents' thoughts on failure incidents that truly betray their expectations of minimum service standards (see Bitner et al. 1990).

This survey is about your experiences with online service failures that you, the customer, may have encountered on e-commerce websites. An online service failure, in this survey questionnaire, refers to a negative experience that occurs whenever the website is incapable of offering the necessary technological capabilities essential for you to accomplish your transactional activities and/or objectives.

\section{Common examples include}

- $\quad$ Search function fails when you are trying to locate a product

- $\quad$ Credit card rejected when you are paying for a transaction

- No confirmation of purchase after payment

- $\quad$ Takes an unreasonably long time to process your requests

- $\quad$ Online customer service does not respond to your query

- $\quad$ Charging you for products/services for which you did not request

- $\quad$ Payment process fails during submission of your personal information

Following which, respondents were requested to indicate their frequency of performing online transactions. 


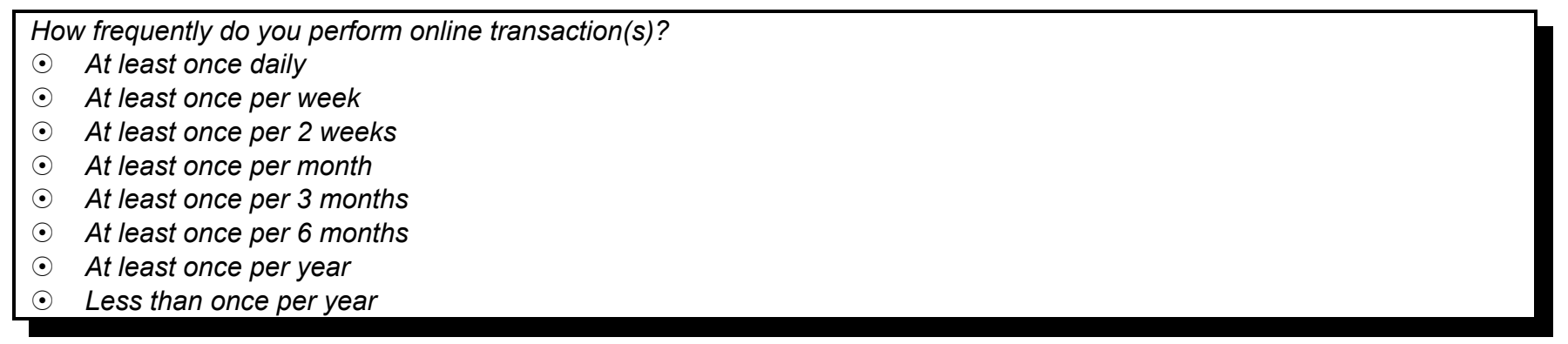

Respondents were then asked to specify whether they have prior experience with e-commerce service failure. This single filtering question eliminated respondents with no prior experience of e-commerce service failure.

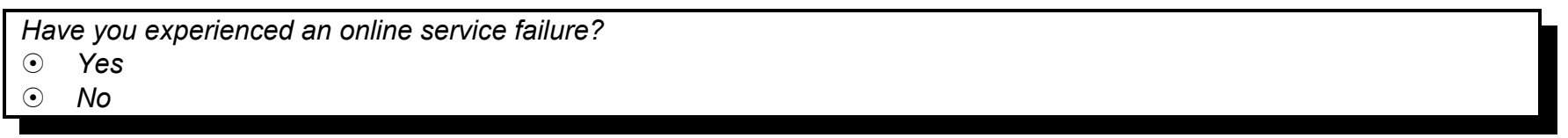

To verify respondents' prior experience with e-commerce service failures, they were prompted to indicate the time that has elapsed since the occurrence of the failure.

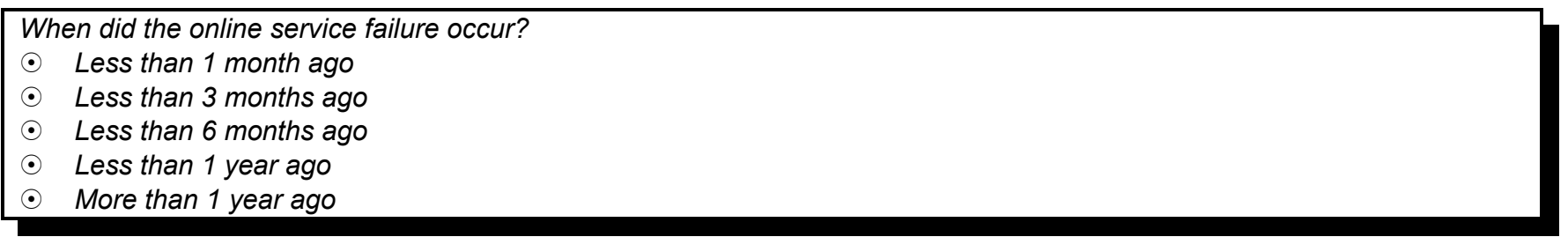

Next, respondents were instructed to either choose from a variety of e-merchants on whose site a failure has occurred or provide a description of the website on which they have encountered the e-commerce service failure. In line with Keaveney's (1995) advice, such a question offers a certain degree of structure to the types of website for which e-commerce service failures may occur, without necessarily limiting respondents to the prespecified list.

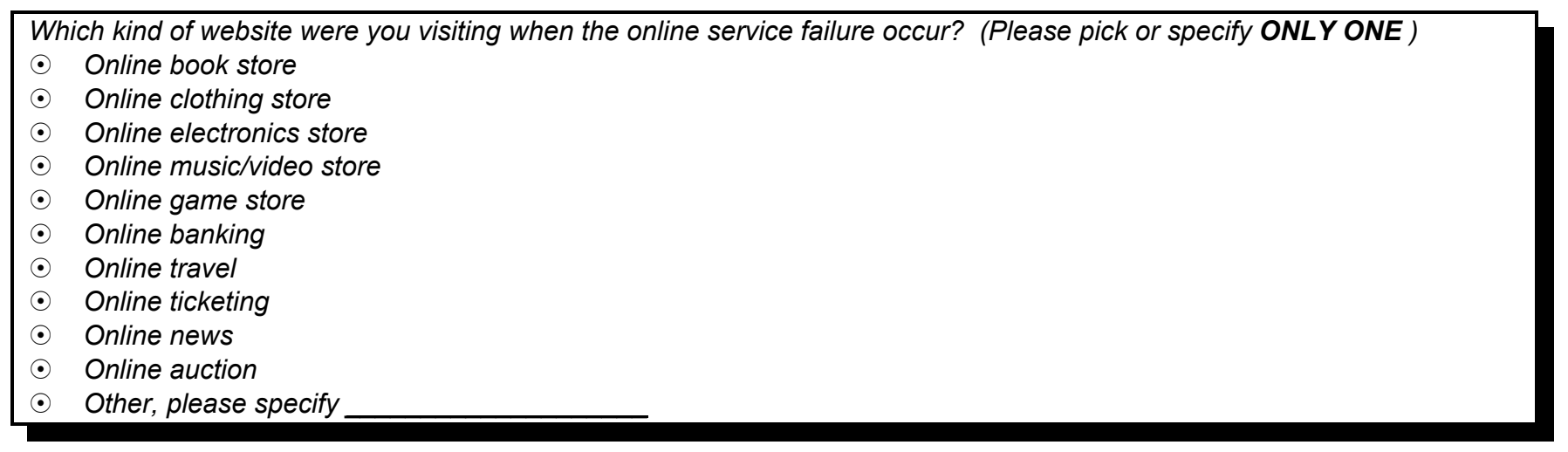

Respondents were then questioned on the purpose of their visit to the e-commerce website.

Please describe in detail your purpose for visiting the website on which you have experienced the online service failure

Stating the purpose of the visit is essential to discern respondents' transactional objectives because we do not presume that consumers transact online for the sole purpose of maximizing utility. By getting respondents to state the purpose of their visit to the e-commerce website, we gleaned valuable background information on the situational context within which the e-commerce service failure occurred. 
The subsequent question touched on the actual phenomenon of interest by requesting respondents to elaborate on the e-commerce service failure experienced, with additional probes for details. Because our theory development is confined to transactional failures in order to generate prescriptions for web interface design, the probes were deliberately phrased to emphasize the recollection of problems related to web-enabled features on e-commerce websites.

Please describe in detail the online transaction you were conducting when you experienced the online service failure as well as the events leading to this failure. You should elaborate on the following:

1. What you had managed to accomplish on the website prior to the occurrence of the online service failure

2. Details of the online service failure experienced [Please be specific on the website feature(s) involved and why you perceive these feature(s) to have failed]

After describing the e-commerce service failure, respondents were further prompted to reveal any negative consequences they may have suffered due to the failure incident.

Please describe in detail the negative consequences you have suffered as a result of the online service failure you have experienced

As respondents may have been exposed to multiple episodes of e-commerce service failures, the same format of questioning was repeated twice to stimulate each respondent to recall a minimum of one and a maximum of three critical incidents. A diagrammatic flow of the online survey questionnaire is depicted in Figure C1.

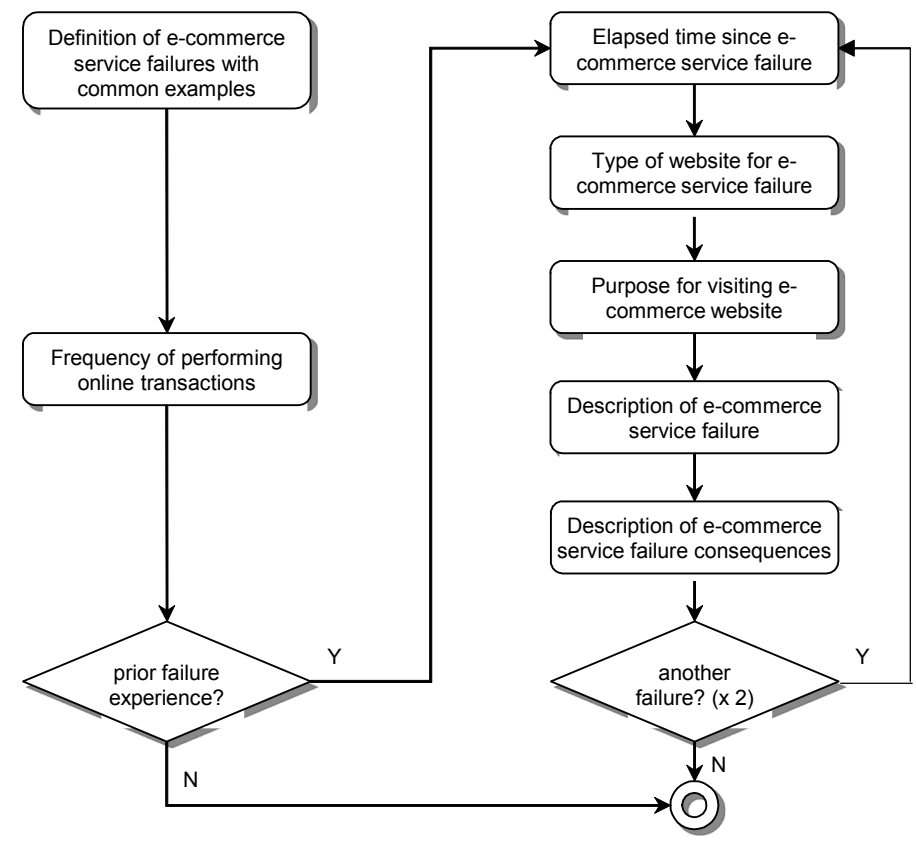

Figure C1. Diagrammatic Flow of Online Survey Questionnaire

In answering the questionnaire, it should be noted that respondents were never told to analyze why the failure incident(s) occurred. Rather, they were expected to merely narrate events that had transpired — something people do quite effortlessly (Bitner et al. 1990; Nyquist and Booms 1987). 


\section{Appendix C References}

Bitner, M. J. 1990. "Evaluating Service Encounters: The Effects of Physical Surroundings and Employee Responses,” Journal of Marketing (54:1), pp. 69-82.

Boyer, K. K., Hallowell, R., and Roth, A. V. 2002. "E-Services: Operating Strategy: A Case Study and a Method for Analyzing Operational Benefits," Journal of Operations Management (20:2), pp.175-188.

Keaveney, S. M. 1995. “Customer Switching Behavior in Service Industries: An Exploratory Study,” Journal of Marketing (59:2), pp. 71-82. Nyquist, J. D., and Booms, B. H. 1987. "Measuring Services Value From the Consumer Perspective," in Add Value to Your Service, C. Surprenant, (ed.), Chicago: American Marketing Association, 1987, pp. 13-16.

Stanton, J. M., and Rogelberg, S. G. 2001. “Using Internet/Intranet Web Pages to Collect Organizational Research Data,” Organizational Research Methods (4:3), pp. 200-217.

\section{Appendix D}

\section{Content Analytical Procedures for E-Commerce Service Failure Incidents}

To begin, two judges were recruited to refine the wording of failure dimensions in our classification system. The two judges were postgraduate students pursuing a master's degree at a large North American university and had taken courses on topics related to e-business. We randomly extracted 77 ( or $\sim 20 \%$ ) incidents from the sample and assigned to the two judges the task of sorting them into our classification system of e-commerce service failures. The entire sorting exercise was semi-structured. Judges were instructed to place each incident into one of the preexisting failure dimensions or to create an extra dimension if they were unsure of its placement. Because each incident contains descriptive accounts on the purpose of the online transaction as well as events that transpired before and during the occurrence of an e-commerce service failure, judges were coached on how to pinpoint the predominant cause of the failure. For instance, if inaccurate, incomplete, irrelevant, or untimely ordering information was displayed for an impending purchase, judges were told to classify the incident under one of the four constituent dimensions of information failure accordingly. Conversely, if orders could not be submitted for an impending purchase, we educated the judges on why the incident should be seen as an occurrence of acquisition functional failure. Finally, if it takes a long time for the order to be processed, judges were advised to view the incident as delayed system failure.

Upon the completion of the sorting exercise, the judges were consulted on the phrasing of the failure dimensions and modifications were made whenever necessary. Then, the judges were again presented with the same 77 incidents to be sorted into the refined failure dimensions. Two types of reliabilities were computed: (1) intra-judge (i.e., extent to which a single judge assigns an identical incident to the same failure dimension in both classification exercises) and (2) inter-judge (i.e., extent to which different judges assign an identical incident to the same failure dimension). This second sorting exercise of the 77 incidents yielded intra- and inter-reliabilities exceeding the recommended threshold of 0.70 (Boyatzis 1998), signifying both consistency in judges' interpretation of the failure dimensions and congruency between judges with regard to the classification of e-commerce service failure incidents.

Next, we split the remaining 297 (374-77) accounts of e-commerce service failures into subsamples of 77 and 220 accounts respectively. We followed the same sorting protocol twice more to classify these subsamples according to our classification system. Content analysis was divided into a series of steps to ensure that newly created dimension(s), if any, were identified progressively, thereby reducing fatigue on the part of the judges (see Figure D1).

\section{Appendix D References}

Boyatzis, R. E. 1998. Transforming Qualitative Information: Thematic Analysis and Code Development, Thousand Oaks, CA: Sage Publications. 


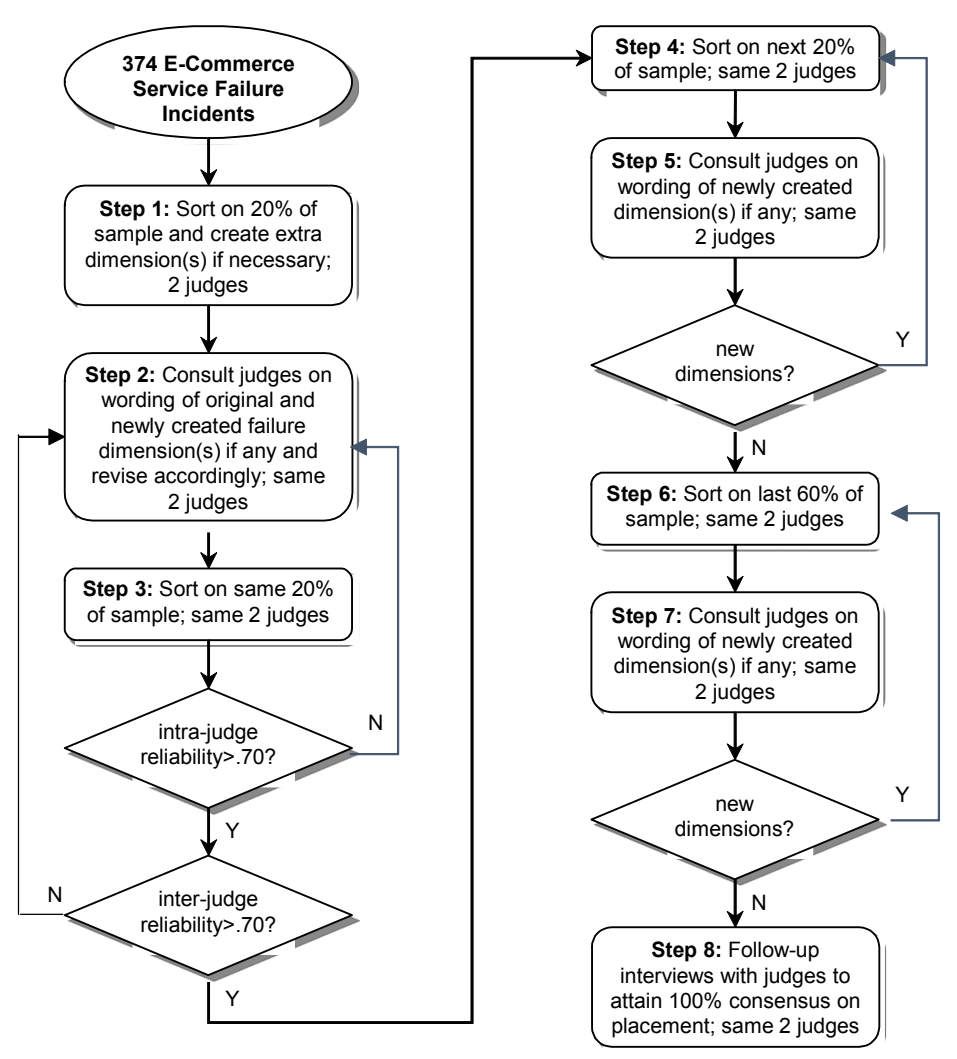

Figure D1. Diagrammatic Flow of Content Analytical Procedures for E-Commerce Service Failure Incidents 


\section{Appendix E}

\section{Detailed Breakdown of E-Commerce Service Failure Incidents}

\begin{tabular}{|c|c|c|c|c|}
\hline \multirow[b]{2}{*}{ Construct } & \multirow[b]{2}{*}{ Definition (Event in which...) } & \multicolumn{3}{|c|}{ Incident Coding } \\
\hline & & $\begin{array}{l}\text { No. Unique } \\
\text { Incidents* } \\
{[\%]}\end{array}$ & $\begin{array}{l}\text { No. } \\
\text { Common } \\
\text { Incidents } \\
\text { [\%] }\end{array}$ & $\begin{array}{l}\text { Inter-Judge } \\
\text { Reliability }{ }^{\ddagger}\end{array}$ \\
\hline \multicolumn{5}{|l|}{ Information Failures } \\
\hline $\begin{array}{l}\text { Inaccurate } \\
\text { Information }\end{array}$ & $\begin{array}{l}\text { Information provided on an e-commerce website contains errors that } \\
\text { misinform consumers in making transactional decisions }\end{array}$ & 37 [9.89\%] & $28[7.49 \%]$ & 0.76 \\
\hline $\begin{array}{l}\text { Incomplete } \\
\text { Information }\end{array}$ & $\begin{array}{l}\text { Information provided on an e-commerce website is insufficient to aid } \\
\text { consumers in making transactional decisions }\end{array}$ & 27 [7.22\%] & $20[5.35 \%]$ & 0.74 \\
\hline $\begin{array}{l}\text { Irrelevant } \\
\text { Information }\end{array}$ & $\begin{array}{l}\text { Information provided on an e-commerce website cannot be utilized } \\
\text { by consumers in making transactional decisions }\end{array}$ & $11[2.94 \%]$ & 9 [2.41\%] & 0.82 \\
\hline Untimely Information & $\begin{array}{l}\text { Information provided on an e-commerce website is not updated to } \\
\text { support consumers in making transactional decisions }\end{array}$ & $25[6.68 \%]$ & 20 [5.35\%] & 0.80 \\
\hline \multicolumn{5}{|l|}{ Functional Failures } \\
\hline $\begin{array}{l}\text { Needs Recognition } \\
\text { Failure }\end{array}$ & $\begin{array}{l}\text { Functionalities of an e-commerce website are incapable of assisting } \\
\text { consumers to formulate their needs and preferences for products } \\
\text { and/or services }\end{array}$ & $3[0.80 \%]$ & $3[0.80 \%]$ & 1.00 \\
\hline $\begin{array}{l}\text { Alternatives } \\
\text { Identification Failure }\end{array}$ & $\begin{array}{l}\text { Functionalities of an e-commerce website are incapable of assisting } \\
\text { consumers to gather information on and source for interested } \\
\text { products and/or services }\end{array}$ & 8 [2.14\%] & $8[2.14 \%]$ & 1.00 \\
\hline $\begin{array}{l}\text { Alternatives } \\
\text { Evaluation Failure }\end{array}$ & $\begin{array}{l}\text { Functionalities of an e-commerce website are incapable of assisting } \\
\text { consumers to draw comparisons among interested products and/or } \\
\text { services }\end{array}$ & $1[0.27 \%]$ & $1[0.27 \%]$ & 1.00 \\
\hline Acquisition Failure & $\begin{array}{l}\text { Functionalities of an e-commerce website are incapable of assisting } \\
\text { consumers to place orders for desired products and/or services }\end{array}$ & $63[16.84 \%]$ & $52[13.90 \%]$ & 0.83 \\
\hline $\begin{array}{l}\text { Post-Purchase } \\
\text { Failure }\end{array}$ & $\begin{array}{l}\text { Functionalities of an e-commerce website are incapable of assisting } \\
\text { consumers to: (1) obtain purchased products and/or services; }(2) \\
\text { solicit advice on ways to maximize the utility of purchased products } \\
\text { and/or services, and; (3) dispose of unwanted products and/or } \\
\text { services. }\end{array}$ & $26[6.95 \%]$ & $21[5.61 \%]$ & 0.81 \\
\hline \multicolumn{5}{|l|}{ System Failures } \\
\hline Inaccessibility & Services of an e-commerce website are not accessible & $73[19.52 \%]$ & $64[17.11 \%]$ & 0.88 \\
\hline Non-Adaptability & $\begin{array}{l}\text { Services of an e-commerce website are unable to accommodate } \\
\text { diverse content and usage patterns }\end{array}$ & 18 [4.81\%] & $17[4.55 \%]$ & 0.94 \\
\hline Non-Navigability & Services of an e-commerce website are difficult to navigate & $28[7.49 \%]$ & $21[5.61 \%]$ & 0.75 \\
\hline Delay & Services of an e-commerce website are inordinately slow in access & $33[8.82 \%]$ & $30[8.02 \%]$ & 0.91 \\
\hline Insecurity & $\begin{array}{l}\text { Services of an e-commerce website are not safeguarded against } \\
\text { unsanctioned access by unauthorized individuals }\end{array}$ & $7[1.87 \%]$ & $7[1.87 \%]$ & 1.00 \\
\hline \multicolumn{5}{|l|}{ Nontechnological } \\
\hline Mischarging & $\begin{array}{l}\text { E-commerce website charges the consumer for unauthorized or } \\
\text { unfulfilled purchases }\end{array}$ & 9 [2.41\%] & $5[1.34 \%]$ & 0.56 \\
\hline $\begin{array}{l}\text { Product Delivery } \\
\text { Problems }\end{array}$ & $\begin{array}{l}\text { Product(s) purchased on an e-commerce website is not delivered or } \\
\text { damaged during delivery }\end{array}$ & $31[8.29 \%]$ & $15[4.01 \%]$ & 0.48 \\
\hline $\begin{array}{l}\text { Unresponsive to } \\
\text { Customer Enquiries }\end{array}$ & Responses to online customer enquiries are not forthcoming & $18[4.81 \%]$ & 9 [2.41\%] & 0.50 \\
\hline
\end{tabular}

* Total number of unique incidents assigned to each category by both judges

${ }^{\dagger}$ Total number of identical incidents assigned to each category by both judges

${ }^{\ddagger}$ Number of common incidents divided by number of unique incidents 


\section{Appendix F}

\section{Content Analytical Procedures for E-Commerce Service Failure Consequences}

Like the classification of e-commerce service failure incidents, the ultimate aim of this content analysis is to unambiguously classify each account of negative consequence under one of the three expectation disconfirmation constructs (i.e., disconfirmed outcome expectancy, disconfirmed process expectancy, and disconfirmed cost expectancy). To prevent priming effects from contaminating the classification results, two new judges with similar qualification were recruited for sorting e-commerce service failure consequences. We randomly extracted 77 (or $\sim 20 \%$ ) accounts of negative consequences from the sample and assigned them to the two judges to be sorted. To clarify the failure context within which the negative consequences manifest, judges were not only presented with accounts of these negative consequences, but they were also given descriptions of corresponding e-commerce service failure incidents. Judges were instructed to place each account into one of the three disconfirmation constructs or to create an extra variable if they were unsure of its placement.

Once the sorting was completed, the judges were consulted on the phrasing of the disconfirmation constructs, with modifications made whenever necessary. Based on the revised wording of the disconfirmation constructs, the judges were again allocated the same 77 accounts to be sorted. This second sorting exercise yielded intra- and inter-reliabilities exceeding 0.70 . The remaining 297 accounts of negative consequences were further divided into subsamples of 77 and 220 accounts respectively and identical sorting procedures were carried out twice more to classify these subsamples (see Figure F1).

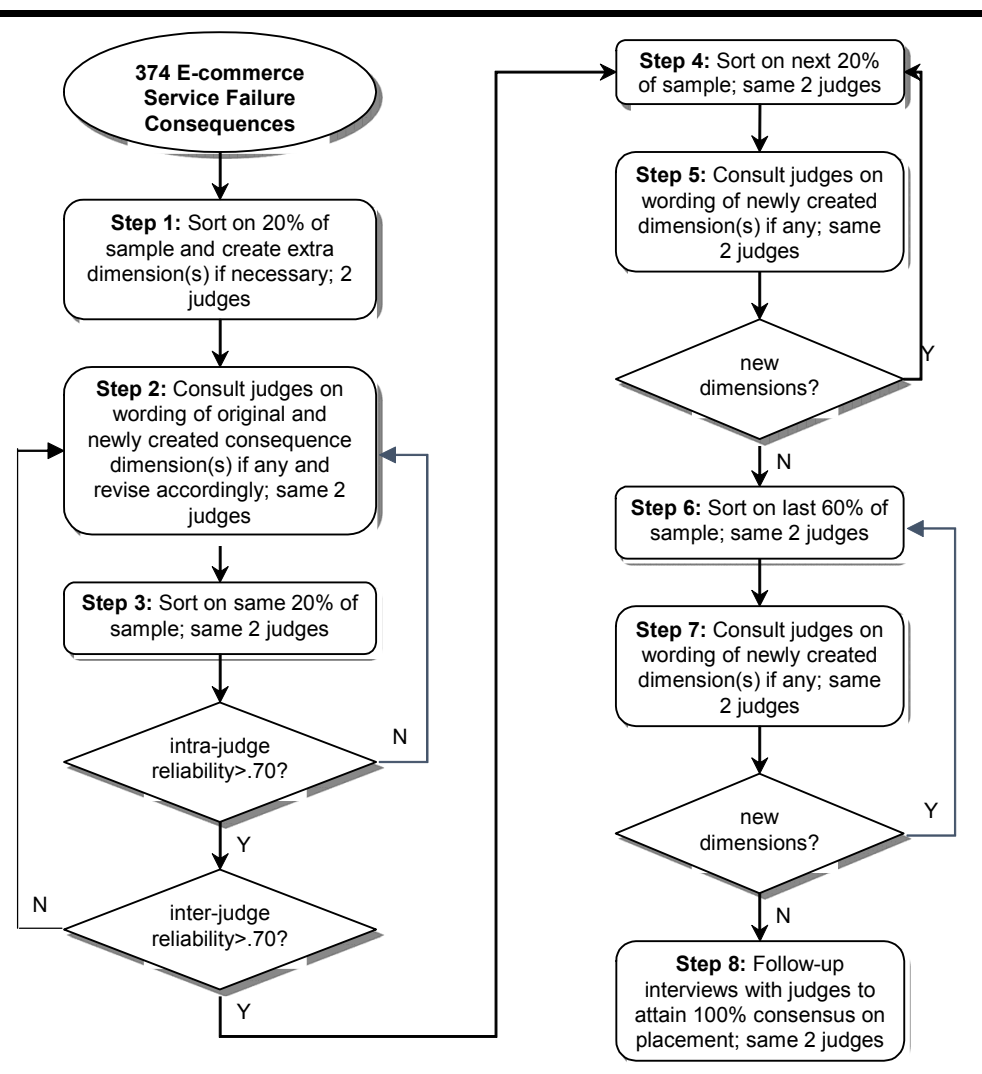

Figure F1. Diagrammatic Flow of Content Analytical Procedures for E-Commerce Service Failure Consequences 


\section{Appendix G}

\section{Classification of Exemplary E-Commerce Service Failure Consequences}

\begin{tabular}{|c|c|c|c|c|}
\hline $\begin{array}{r}\begin{array}{r}\text { Negative } \\
\text { Consequence }\end{array} \\
\text { Failure Dimension }\end{array}$ & $\begin{array}{l}\text { Disconfirmed Outcome } \\
\text { Expectancy }\end{array}$ & $\begin{array}{c}\text { Disconfirmed Process } \\
\text { Expectancy }\end{array}$ & $\begin{array}{l}\text { Disconfirmed Cost } \\
\text { Expectancy }\end{array}$ & $\begin{array}{c}\text { No Disconfirmed } \\
\text { Expectancy }\end{array}$ \\
\hline \multicolumn{5}{|l|}{ Information Failures } \\
\hline $\begin{array}{l}\text { Inaccurate } \\
\text { Information }\end{array}$ & \begin{tabular}{|l|} 
[Failure] I was attempting to \\
purchase a (fairly rare) music \\
CD on the website. I located \\
the item I wanted and was \\
able to put it in my "shopping \\
cart." The failure was that \\
when I attempted to actually \\
complete the transaction, I \\
was notified at that point that \\
the item was not in stock, so I \\
was not able to buy it. \\
[Consequence] I spent a \\
small amount of time \\
searching for and ordering \\
the CD, and I was unable to \\
purchase what I wanted.
\end{tabular} & $\begin{array}{l}\text { [Failure] I clicked on the } \\
\text { sweepstakes website and got } \\
\text { the code. I then went to the } \\
\text { rewards program to enter the } \\
\text { code. I was told I had to } \\
\text { register for the rewards pro- } \\
\text { gram which I did. Then, I got } \\
\text { a confirmation e-mail I had to } \\
\text { click on to verify my registra- } \\
\text { tion, which I did. When I was } \\
\text { finally allowed to enter my } \\
\text { code, I was told it was NOT a } \\
\text { valid code! } \\
\text { [Consequence] I contacted } \\
\text { the website hosting the } \\
\text { sweeps. They said the code } \\
\text { was valid and I must have } \\
\text { entered it wrongly. I wrote } \\
\text { back again and was told the } \\
\text { sweeps was over and that } \\
\text { there was nothing they could } \\
\text { do about it! }\end{array}$ & $\begin{array}{l}\text { [Failure] I was trying to find } \\
\text { some good looking and } \\
\text { stylish clothes on the } \\
\text { website. However, what I } \\
\text { have seen online is not what } \\
\text { came in the mail; the style } \\
\text { and color are different. } \\
\text { [Consequence] I will just go } \\
\text { to the store the next time } \\
\text { because it wastes my time } \\
\text { doing it online. }\end{array}$ & N/A \\
\hline $\begin{array}{l}\text { Incomplete } \\
\text { Information }\end{array}$ & $\begin{array}{l}\text { [Failure] A few times, I was } \\
\text { looking to buy some hair } \\
\text { products online. After } \\
\text { spending a lot of time adding } \\
\text { products to shopping carts } \\
\text { and entering my contact } \\
\text { information, I was informed } \\
\text { that the companies did not } \\
\text { mail orders to places outside } \\
\text { of US. This was never made } \\
\text { known to me before I initiated } \\
\text { the transaction. } \\
\text { [Consequence] The negative } \\
\text { consequence was that I was } \\
\text { not able to obtain the items } \\
\text { that I wanted from the } \\
\text { websites. }\end{array}$ & $\begin{array}{l}\text { [Failure] I was trying to find } \\
\text { out where the funds were } \\
\text { going for a refund that I was } \\
\text { getting. Online it said "refund } \\
\text { issued," but not to what } \\
\text { account. } \\
\text { [Consequence] I quit using } \\
\text { the services of that company } \\
\text { because it was just too } \\
\text { difficult to reach them. It was } \\
\text { as if they had the website set } \\
\text { up like that on purpose. }\end{array}$ & $\begin{array}{l}\text { [Failure] I wanted to change } \\
\text { the [programming] of my cell } \\
\text { phone online, only to } \\
\text { discover I had to call again to } \\
\text { program the phone and } \\
\text { waste another two hours on } \\
\text { hold. The programming } \\
\text { instructions could easily be } \\
\text { put online to be more } \\
\text { accessible. } \\
\text { [Consequence] Having to } \\
\text { contact customer service and } \\
\text { waiting for untold amounts of } \\
\text { time detracts from my } \\
\text { employer and family. }\end{array}$ & N/A \\
\hline $\begin{array}{l}\text { Irrelevant } \\
\text { Information }\end{array}$ & \begin{tabular}{|l|} 
[Failure] When I call up the \\
customer service to reset my \\
[air miles] account, I was told \\
to go online to do so. I tried it \\
online and was faced with the \\
same problem that can only \\
be resolved by calling \\
customer service. I finally \\
gave up. \\
[Consequence] I lost my air \\
\end{tabular} & $\begin{array}{l}\text { [Failure] I sent an email to } \\
\text { the website to confirm if my } \\
\text { purchase was received. I } \\
\text { received an email response } \\
\text { from the Helpdesk that was } \\
\text { of no help. They gave me a } \\
\text { list of things to check that } \\
\text { had no bearings on what had } \\
\text { happened. } \\
\text { [Consequence] It is very }\end{array}$ & $\begin{array}{l}\text { [Failure] I have not been on } \\
\text { the website before. I was } \\
\text { trying to purchase the gift } \\
\text { card, but couldn't find any } \\
\text { option for Canadian } \\
\text { purchasers and I don't know } \\
\text { if Canadians can purchase } \\
\text { them. I got frustrated and } \\
\text { gave up! } \\
\text { [Consequence] Wasted time }\end{array}$ & N/A \\
\hline
\end{tabular}




\begin{tabular}{|c|c|c|c|c|}
\hline 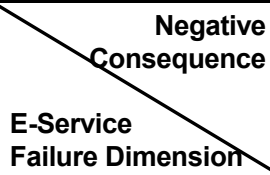 & $\begin{array}{c}\text { Disconfirmed Outcome } \\
\text { Expectancy }\end{array}$ & $\begin{array}{c}\text { Disconfirmed Process } \\
\text { Expectancy }\end{array}$ & $\begin{array}{l}\text { Disconfirmed Cost } \\
\text { Expectancy }\end{array}$ & $\begin{array}{l}\text { No Disconfirmed } \\
\text { Expectancy }\end{array}$ \\
\hline & $\begin{array}{l}\text { miles for that trip and since } \\
\text { then I have given up on trying } \\
\text { to travel by SIA. }\end{array}$ & $\begin{array}{l}\text { frustrating, as I first try to } \\
\text { understand what has } \\
\text { happened and retrace the } \\
\text { whole process. Most of the } \\
\text { staff on the Helpdesk are of } \\
\text { little use. What frustrates me } \\
\text { is that they don't provide any } \\
\text { valuable solutions. They just } \\
\text { pass the buck. I have } \\
\text { worked on Helpdesk before, } \\
\text { so I understand the process. }\end{array}$ & $\begin{array}{l}\text { on the site while at work and } \\
\text { gave up. Left confused and } \\
\text { frustrated. }\end{array}$ & \\
\hline $\begin{array}{l}\text { Untimely } \\
\text { Information }\end{array}$ & $\begin{array}{l}\text { [Failure] Only when I saw } \\
\text { that the payment did not go } \\
\text { through to my credit card } \\
\text { statement, I became aware } \\
\text { that the transaction was } \\
\text { never recorded on their end. } \\
\\
\text { [Consequence] I had to } \\
\text { repeat the whole transaction } \\
\text { all over again. }\end{array}$ & $\begin{array}{l}\text { [Failure] Transferred money } \\
\text { from my chequing account to } \\
\text { make a payment for a utility } \\
\text { service. But, the chequing } \\
\text { account balance did not } \\
\text { reflect promptly the updated } \\
\text { balance to indicate that the } \\
\text { money has been debited. } \\
\text { [Consequence] Confusion } \\
\text { and doubt whether the bill } \\
\text { has been settled before the } \\
\text { due date. }\end{array}$ & $\begin{array}{l}\text { [Failure] I wished to sign in } \\
\text { after receiving the recovered } \\
\text { user name and password. } \\
\text { Having to re-register and } \\
\text { being unable to do so when } \\
\text { they claim I am already } \\
\text { registered. The website will } \\
\text { still not recognize and allow } \\
\text { me to sign in after all that I } \\
\text { have done. } \\
\text { [Consequence] Waste of } \\
\text { time and frustration. }\end{array}$ & N/A \\
\hline \multicolumn{5}{|l|}{ Functional Failures } \\
\hline $\begin{array}{l}\text { Needs Recognition } \\
\text { Failure }\end{array}$ & N/A & $\begin{array}{l}\text { [Failure] Looking to buy } \\
\text { something online and } \\
\text { searching for the item I } \\
\text { wanted, I can't find it because } \\
\text { the website cannot help me } \\
\text { to pinpoint the item I am } \\
\text { looking for. } \\
\text { [Consequence] I have to go } \\
\text { through the whole product } \\
\text { catalogue and check each } \\
\text { item. }\end{array}$ & N/A & N/A \\
\hline $\begin{array}{l}\text { Alternatives } \\
\text { Identification } \\
\text { Failure }\end{array}$ & $\begin{array}{l}\text { [Failure] There was no clear } \\
\text { information as to which of the } \\
\text { video cards would be } \\
\text { appropriate. Since the site } \\
\text { brands itself as being "user- } \\
\text { friendly," I expected that I } \\
\text { would be able to find more } \\
\text { complete information there } \\
\text { than was available. Since } \\
\text { they had no on-line means to } \\
\text { check what models of video } \\
\text { card would work with what } \\
\text { kinds of hardware, I view it as } \\
\text { a service failure. } \\
\\
\text { [Consequence] When I } \\
\text { eventually did get a new } \\
\text { video card (which was } \\
\text { compatible), it's possible I } \\
\text { purchased a more expensive } \\
\text { model than necessary to } \\
\text { meet my needs. }\end{array}$ & $\begin{array}{l}\text { [Failure] The online search } \\
\text { function for the store did not } \\
\text { work. I know the store } \\
\text { carried the product I wanted } \\
\text { but I kept getting no search } \\
\text { results. } \\
\text { [Consequence] I gave up } \\
\text { searching for the product } \\
\text { online. }\end{array}$ & $\begin{array}{l}\text { [Failure] I visited } \\
\text { Amazon.com to search for a } \\
\text { DVD I wanted to purchase. I } \\
\text { have often searched for and } \\
\text { found things on Amazon.com } \\
\text { successfully, but because } \\
\text { this DVD turned out to be out } \\
\text { of print, it made it harder to } \\
\text { find at a decent price. The } \\
\text { only DVDs for sale I could } \\
\text { find were over } \$ 50 \text {, which I } \\
\text { was not willing to spend. I } \\
\text { couldn't imagine that out of } \\
\text { all the sellers on Amazon, } \\
\text { there wasn't a used DVD for } \\
\text { cheaper. After shuffling and } \\
\text { searching around for a very } \\
\text { long time, I was able to dig } \\
\text { deeper than the first search } \\
\text { results and find a DVD for } \\
\$ 30 \text {. I think the search } \\
\text { function is poorly designed. I } \\
\text { should have been able to find }\end{array}$ & N/A \\
\hline
\end{tabular}




\begin{tabular}{|c|c|c|c|c|}
\hline $\begin{array}{r}\begin{array}{r}\text { Negative } \\
\text { Consequence }\end{array} \\
\text { E-Service }\end{array}$ & $\begin{array}{c}\text { Disconfirmed Outcome } \\
\text { Expectancy }\end{array}$ & $\begin{array}{c}\text { Disconfirmed Process } \\
\text { Expectancy }\end{array}$ & $\begin{array}{l}\text { Disconfirmed Cost } \\
\text { Expectancy }\end{array}$ & $\begin{array}{l}\text { No Disconfirmed } \\
\text { Expectancy }\end{array}$ \\
\hline & & & $\begin{array}{l}\text { the cheaper DVD without } \\
\text { taking such a long time to } \\
\text { search. } \\
\text { [Consequence] Takes too } \\
\text { long to search. }\end{array}$ & \\
\hline $\begin{array}{l}\text { Alternatives } \\
\text { Evaluation Failure }\end{array}$ & N/A & $\begin{array}{l}\text { [Failure] I recently tried to } \\
\text { order several items from a } \\
\text { retail store via their website, } \\
\text { www.kohls.com. After } \\
\text { choosing several products } \\
\text { and entering the desired } \\
\text { quantities, I decided to visit } \\
\text { Overstock.com to compare } \\
\text { prices for similar items before } \\
\text { placing the order with Kohl's. } \\
\text { Before switching websites, I } \\
\text { created a username and } \\
\text { password on the Kohl's } \\
\text { website, assuming that my } \\
\text { "basket" contents would be } \\
\text { saved. However, after } \\
\text { navigating to the Overstock } \\
\text { website and then returning to } \\
\text { Kohls.com, my basket } \\
\text { contents had been cleared. } \\
\text { Other shopping sites that I've } \\
\text { used tend to be very sticky } \\
\text { with my basket contents even } \\
\text { when I am not logged in as a } \\
\text { user. As long as I'm entering } \\
\text { from the same IP address, } \\
\text { my shopping basket contents } \\
\text { are usually retained. But this } \\
\text { was not the case on the } \\
\text { Kohl's site. I did not recreate } \\
\text { my online order with them. } \\
\text { [Consequence] I was so } \\
\text { frustrated with the process } \\
\text { that I did not place any order. }\end{array}$ & N/A & N/A \\
\hline Acquisition Failure & $\begin{array}{l}\text { [Failure] I wanted to } \\
\text { pre-order } 2 \text { video games. } \\
\text { Everything seemed to be fine } \\
\text { as I already have an account } \\
\text { with the e-commerce } \\
\text { website. I logged in and went } \\
\text { about ordering the games I } \\
\text { wanted. Nothing seemed to } \\
\text { be amiss and I was able to } \\
\text { successfully placed order for } \\
\text { the games. However, when } \\
\text { one of the games was due to } \\
\text { be shipped, I tried logging } \\
\text { into the account to check the } \\
\text { shipping status but was } \\
\text { informed that my account has } \\
\text { been suspended and no } \\
\text { explanation was provided. }\end{array}$ & $\begin{array}{l}\text { [Failure] I wanted to pur- } \\
\text { chase several items online. } \\
\text { However, the transaction } \\
\text { failed and wouldn't process } \\
\text { even though the items were } \\
\text { accepted into the shopping } \\
\text { cart. } \\
\text { [Consequence] I have to go } \\
\text { back and resubmit once I am } \\
\text { sure my card has not been } \\
\text { charged or the charges have } \\
\text { been cleared from pending. }\end{array}$ & $\begin{array}{l}\text { [Failure] I wanted to pur- } \\
\text { chase cinema tickets online. } \\
\text { I could find the movie, } \\
\text { theatre, and time. However, } \\
\text { when I got to the credit card } \\
\text { payment, the (externally- } \\
\text { powered) transaction module } \\
\text { failed to validate my trans- } \\
\text { actions. I pay with that card } \\
\text { very often on other Websites } \\
\text { so I don't think it was due to } \\
\text { my card or me entering the } \\
\text { wrong info. I tried } 4 \text { times to } \\
\text { reprocess the payment but it } \\
\text { never managed to process it. } \\
\text { [Consequence] I lost time } \\
\text { trying to complete the } \\
\text { transaction many times. It }\end{array}$ & $\begin{array}{l}\text { [Failure] I wanted to } \\
\text { purchase a product } \\
\text { online but I was } \\
\text { denied when trying } \\
\text { to make payment. } \\
\text { [Consequence] No } \\
\text { negative } \\
\text { consequence. }\end{array}$ \\
\hline
\end{tabular}




\begin{tabular}{|c|c|c|c|c|}
\hline 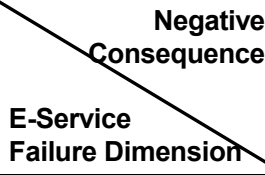 & $\begin{array}{l}\text { Disconfirmed Outcome } \\
\text { Expectancy }\end{array}$ & $\begin{array}{c}\text { Disconfirmed Process } \\
\text { Expectancy }\end{array}$ & $\begin{array}{l}\text { Disconfirmed Cost } \\
\text { Expectancy }\end{array}$ & $\begin{array}{l}\text { No Disconfirmed } \\
\text { Expectancy }\end{array}$ \\
\hline & $\begin{array}{l}\text { [Consequence] Although I } \\
\text { did not suffer any monetary } \\
\text { losses, I was quite unhappy } \\
\text { that my account was sus- } \\
\text { pended without any notifica- } \\
\text { tion and for no apparent } \\
\text { reason. I find it extremely } \\
\text { inconvenient to bother to } \\
\text { even create a new account or } \\
\text { to contact the customer } \\
\text { service personnel to try to } \\
\text { fight my case. }\end{array}$ & & $\begin{array}{l}\text { was not a very important } \\
\text { purchase as I could buy the } \\
\text { movie tickets at the theatre } \\
\text { so I did not suffer much from } \\
\text { this failure. Sill it was a loss } \\
\text { of time/effort + annoying to } \\
\text { have the transaction failed. }\end{array}$ & \\
\hline $\begin{array}{l}\text { Post-Purchase } \\
\text { Failure }\end{array}$ & $\begin{array}{l}\text { [Failure] I wanted to order a } \\
\text { video game through } \\
\text { Amazon.ca, which I had } \\
\text { successfully done. I was } \\
\text { able to add the item to my } \\
\text { cart and successfully check } \\
\text { out. A couple hours later, I } \\
\text { realized that I had forgotten } \\
\text { to order another item. } \\
\text { Amazon had the option to } \\
\text { amend orders before they } \\
\text { were processed, but when I } \\
\text { returned to my account; my } \\
\text { order had already been } \\
\text { processed. My original order } \\
\text { was over } \$ 39, \text { which qualified } \\
\text { it for free shipping, but the } \\
\text { second item that I wanted to } \\
\text { order was not. I did not want } \\
\text { to place another order and } \\
\text { have to pay for shipping, } \\
\text { when I could have just added } \\
\text { the second item to go with } \\
\text { the first, and get free shipping } \\
\text { for both items. In the end, I } \\
\text { decided not to order the } \\
\text { second item. } \\
\text { [Consequence] I decided not } \\
\text { to order the second item. } \\
\text { Ever. }\end{array}$ & $\begin{array}{l}\text { [Failure] While I was } \\
\text { searching around for dog } \\
\text { bones on the website, } \\
\text { everything was going well. } \\
\text { My cart was filling up and I } \\
\text { was ready to check out. As I } \\
\text { checked out and entered my } \\
\text { information into the system I } \\
\text { anticipated that I would } \\
\text { receive some kind of } \\
\text { notification that I had made } \\
\text { the purchase. I did not } \\
\text { receive any confirmation } \\
\text { about if my transaction was } \\
\text { successful or completed until } \\
\text { I received the dog bones. } \\
\text { [Consequence] A simple } \\
\text { nervousness and anxiety not } \\
\text { knowing if I had been } \\
\text { charged or not charged } \\
\text { caused a bit of unnecessary } \\
\text { emotion in my life for a period } \\
\text { of time. }\end{array}$ & $\begin{array}{l}\text { [Failure] I never had } \\
\text { problems with this exercise } \\
\text { regarding credit card info. } \\
\text { This time, I was given a } \\
\text { notice when I went to playing } \\
\text { site, on head banner, that my } \\
\text { card was about to expire. I } \\
\text { then went into credit card info } \\
\text { site to update/correct expiry } \\
\text { date but it would not accept } \\
\text { the update after numerous } \\
\text { attempts. The difficulty was } \\
\text { at their end since my info was } \\
\text { correct. } \\
\text { [Consequence] Having to } \\
\text { spend a lot of time finally } \\
\text { getting a hold of someone } \\
\text { real-time on their customer } \\
\text { service site and getting it } \\
\text { corrected by them. }\end{array}$ & $\begin{array}{l}\text { [Failure] No reply to } \\
\text { my e-mail for } \\
\text { additional services } \\
\text { offered and so I } \\
\text { have no idea what } \\
\text { my balance is and, I } \\
\text { refuse to conduct } \\
\text { any further business } \\
\text { with them until } \\
\text { resolved. } \\
\text { [Consequence] No } \\
\text { negative } \\
\text { consequence. }\end{array}$ \\
\hline \multicolumn{5}{|l|}{ System Failures } \\
\hline Inaccessibility & $\begin{array}{l}\text { [Failure] I went to } \\
\text { Amazon.com to purchase a } \\
\text { present for my husband. I } \\
\text { got almost the whole way } \\
\text { through the checkout process } \\
\text { before the website malfunc- } \\
\text { tioned on my browser and I } \\
\text { lost my order. } \\
\text { [Consequence] I got } \\
\text { frustrated and didn't fulfill the } \\
\text { order. }\end{array}$ & $\begin{array}{l}\text { [Failure] Transfer money } \\
\text { from one account to another } \\
\text { account. Click personal } \\
\text { account, key in account } \\
\text { number and password. After } \\
\text { login, it says system is } \\
\text { currently unavailable, go } \\
\text { back later. So I cannot } \\
\text { transfer money. } \\
\text { [Consequence] As I cannot } \\
\text { login, I am not sure if I have } \\
\text { enough money in my Credit } \\
\text { card to pay for purchases } \\
\text { right before I went out that } \\
\text { day. So I need to be careful }\end{array}$ & $\begin{array}{l}\text { [Failure] To buy a pair of } \\
\text { shoes but the website failed } \\
\text { to work on several tries so I } \\
\text { have to keep starting from } \\
\text { scratch and finally made my } \\
\text { purchase. } \\
\text { [Consequence] Just a loss } \\
\text { of time }\end{array}$ & $\begin{array}{l}\text { [Failure] When I } \\
\text { was bidding on an } \\
\text { item online, the } \\
\text { server failed and I } \\
\text { lost my bid. } \\
\text { [Consequence] No } \\
\text { negative } \\
\text { consequence. }\end{array}$ \\
\hline
\end{tabular}




\begin{tabular}{|c|c|c|c|c|}
\hline $\begin{array}{l}\begin{array}{r}\text { Negative } \\
\text { E-Service } \\
\text { Failure Dimensionce }\end{array} \\
\text { Consence }\end{array}$ & $\begin{array}{l}\text { Disconfirmed Outcome } \\
\text { Expectancy }\end{array}$ & $\begin{array}{c}\text { Disconfirmed Process } \\
\text { Expectancy }\end{array}$ & $\begin{array}{l}\text { Disconfirmed Cost } \\
\text { Expectancy }\end{array}$ & $\begin{array}{l}\text { No Disconfirmed } \\
\text { Expectancy }\end{array}$ \\
\hline & & $\begin{array}{l}\text { not to use my credit card too } \\
\text { much to exceed the limit. }\end{array}$ & & \\
\hline Non-Adaptability & $\begin{array}{l}\text { [Failure] I found the product I } \\
\text { was looking for, but was told } \\
\text { the product could not be } \\
\text { shipped to my address } \\
\text { (American website would not } \\
\text { send this particular item to } \\
\text { Canada). } \\
\text { [Consequence] I had to buy } \\
\text { the product locally, used, and } \\
\text { it cost me more than had I } \\
\text { purchased it online, new. }\end{array}$ & $\begin{array}{l}\text { [Failure] When I went to } \\
\text { send an email to inquiry } \\
\text { about my purchase order, the } \\
\text { website asked for my name, } \\
\text { address, account number, } \\
\text { etc. I could not proceed } \\
\text { further because when it came } \\
\text { time to enter my STATE I } \\
\text { couldn't because it was an } \\
\text { American site and the STATE } \\
\text { section could only be filled } \\
\text { out from a pre-installed list. I } \\
\text { am from Canada and I } \\
\text { couldn't override it. } \\
\text { [Consequence] I quit the } \\
\text { purchase because it was just } \\
\text { impossible to complete the } \\
\text { transaction. }\end{array}$ & $\begin{array}{l}\text { [Failure] I was trying to check } \\
\text { my bank balance online. } \\
\text { When I tried to log in, the } \\
\text { website failed, possibly a java } \\
\text { error. I've logged in } \\
\text { hundreds of times before and } \\
\text { this happens every once in a } \\
\text { while. } \\
\text { [Consequence] You have to } \\
\text { wait } 12 \text { minutes for the bank } \\
\text { to time out and log you off } \\
\text { before you can log in again. }\end{array}$ & $\begin{array}{l}\text { [Failure] Website } \\
\text { timed out due to } \\
\text { having long period } \\
\text { of inactivity between } \\
\text { transactions. } \\
\text { [Consequence] No } \\
\text { negative } \\
\text { consequence. }\end{array}$ \\
\hline Non-Navigability & $\begin{array}{l}\text { [Failure] I had accessed the } \\
\text { main page and navigated } \\
\text { through it to the product I was } \\
\text { interested in. At that point I } \\
\text { tried to use the button } \\
\text { allowing me to get more infor- } \\
\text { mation but despite continued } \\
\text { attempts using the button the } \\
\text { required page failed to load } \\
\text { and I got an error message } \\
\text { stating the requested page } \\
\text { was unavailable. I attempted } \\
\text { several times to go back to } \\
\text { the home page and } \\
\text { renavigate to this spot but the } \\
\text { requested page failed to load. } \\
\text { [Consequence] I tried } \\
\text { frequently that day and the } \\
\text { next and then gave up. } \\
\text { While not all that dire in } \\
\text { consequence it was } \\
\text { frustrating in that I was } \\
\text { unable to get the information } \\
\text { I was looking for. }\end{array}$ & $\begin{array}{l}\text { [Failure] I was attempting to } \\
\text { follow a link from another } \\
\text { website. I received a } \\
\text { message stating that this link } \\
\text { was broken. } \\
\text { [Consequence] I could not } \\
\text { access the site. However, I } \\
\text { did a Google search and was } \\
\text { able to find the website. }\end{array}$ & $\begin{array}{l}\text { [Failure] Having reached the } \\
\text { Canadian government web- } \\
\text { site I had found the section } \\
\text { dealing with grants and loans } \\
\text { for my region of the country. } \\
\text { However, upon clicking the } \\
\text { links that purported to lead to } \\
\text { information on how to apply } \\
\text { and to which agency to apply } \\
\text { I found that these links simply } \\
\text { led in circles back to } \\
\text { themselves. } \\
\text { [Consequence] I have had to } \\
\text { deal directly with front line } \\
\text { government workers which is } \\
\text { a waste of both my and their } \\
\text { time in obtaining documen- } \\
\text { tation that should be readily } \\
\text { available through the on line } \\
\text { system. }\end{array}$ & $\begin{array}{l}\text { [Failure] While I was } \\
\text { trying to update } \\
\text { status, checking } \\
\text { mail, viewing } \\
\text { pictures as well as } \\
\text { other networking } \\
\text { pages but I was } \\
\text { unable to do those } \\
\text { things. } \\
\text { [Consequence] No } \\
\text { negative } \\
\text { consequence. }\end{array}$ \\
\hline Delay & $\begin{array}{l}\text { [Failure] I was bidding on } \\
\text { something and was waiting } \\
\text { till the end to put in a last bid } \\
\text { and the site bogged down } \\
\text { and I missed the bid. } \\
\text { [Consequence] Not winning } \\
\text { the item I was bidding on. }\end{array}$ & $\begin{array}{l}\text { [Failure] I choose the laptop I } \\
\text { wanted to buy. Then I was } \\
\text { redirected on the site for the } \\
\text { credit card payment. I } \\
\text { entered my credit card } \\
\text { information, number and } \\
\text { expiry date, and clicked on } \\
\text { PROCESS. Nothing } \\
\text { happened. } 5 \text { minutes later I } \\
\text { clicked again on PROCESS. } \\
\text { Nothing happened again. I } \\
\text { clicked again } 5 \text { minutes later } \\
\text { and it worked. }\end{array}$ & $\begin{array}{l}\text { [Failure] The site failed after I } \\
\text { began my checkout. The site } \\
\text { went real slow and then } \\
\text { locked up. The only way I } \\
\text { could clear it was to log off } \\
\text { the site, go back and try } \\
\text { again at which time the site } \\
\text { worked. } \\
\text { [Consequence] None other } \\
\text { than waiting and re-entering } \\
\text { information. }\end{array}$ & \begin{tabular}{|l|} 
[Failure] When I \\
clicked to pay for a \\
purchase online, it \\
just froze. \\
[Consequence] No \\
negative \\
consequence.
\end{tabular} \\
\hline
\end{tabular}




\begin{tabular}{|c|c|c|c|c|}
\hline $\begin{array}{l}\begin{array}{r}\text { Negative } \\
\text { Consequence }\end{array} \\
\text { Failure Dimension }\end{array}$ & $\begin{array}{c}\text { Disconfirmed Outcome } \\
\text { Expectancy }\end{array}$ & $\begin{array}{c}\text { Disconfirmed Process } \\
\text { Expectancy }\end{array}$ & $\begin{array}{l}\text { Disconfirmed Cost } \\
\text { Expectancy }\end{array}$ & $\begin{array}{l}\text { No Disconfirmed } \\
\text { Expectancy }\end{array}$ \\
\hline & & $\begin{array}{l}\text { [Consequence] The } \\
\text { payment I made passed } 3 \\
\text { times. So I paid } 3 \text { times the } \\
\text { amount due. I called my } \\
\text { credit card issuer and after } \\
\text { explaining, I had to call the } \\
\text { online retailer where I bought } \\
\text { my laptop. I had a refund } \\
\text { after } 3 \text { weeks. }\end{array}$ & & \\
\hline Insecurity & $\begin{array}{l}\text { [Failure] I logged on to my } \\
\text { account and was hijacked to } \\
\text { a site to enter a sweepstakes } \\
\text { instead that had the terms } \\
\text { and conditions to participate } \\
\text { in several levels of "reward } \\
\text { programs." These seem to } \\
\text { lead to endless and } \\
\text { expensive participations. } \\
\text { [Consequence] I have only } \\
\text { tried to participate in such a } \\
\text { survey once and it cost me } \\
\text { shipping on Video Professor, } \\
\text { a cancellation of a cell phone } \\
\text { texting game, and the failure } \\
\text { to complete the rewards } \\
\text { programs. }\end{array}$ & $\begin{array}{l}\text { [Failure] I had no problem } \\
\text { with the service till I started } \\
\text { getting junk from the website, } \\
\text { and when you try to block it, } \\
\text { the vendor won't let you. } \\
\text { [Consequence] Trying to get } \\
\text { information and it keeps } \\
\text { dropping me out and I have } \\
\text { to keep re- connecting in } \\
\text { order to get my work done. }\end{array}$ & N/A & N/A \\
\hline \multicolumn{5}{|c|}{ Nontechnological Failures } \\
\hline Mischarging & $\begin{array}{l}\text { [Failure] I was on } \\
\text { bearshare.com wanting to } \\
\text { join so I could download } \\
\text { some music. I was to pay } \\
\$ 60 \text { for the year after I put in } \\
\text { the information and my card } \\
\text { was charged, the page would } \\
\text { not finish submitting and I } \\
\text { received no membership to } \\
\text { download music and was out } \\
\text { by } \$ 60 \text { and have not heard } \\
\text { from the web site. I have } \\
\text { complained to the website } \\
\text { and requested my money } \\
\text { back. } \\
\text { [Consequence] Having } \\
\text { money withdrawn out of my } \\
\text { accounts with nothing to } \\
\text { show and not receiving a } \\
\text { refund. }\end{array}$ & $\begin{array}{l}\text { [Failure] I was buying an } \\
\text { online game, and after giving } \\
\text { out my credit card info, I was } \\
\text { billed twice for the same } \\
\text { order. } \\
\text { [Consequence] Had to } \\
\text { phone credit card company } \\
\text { and game company. }\end{array}$ & $\begin{array}{l}\text { [Failure] Failed transaction } \\
\text { for a purchase made online } \\
\text { and I got multiple charges on } \\
\text { account. } \\
\text { [Consequence] Had to wait } \\
\text { for charges to clear and be } \\
\text { fixed. }\end{array}$ & $\begin{array}{l}\text { [Failure] I wished to } \\
\text { withdraw my } \\
\text { membership but I } \\
\text { never got my refund. } \\
\text { After several } \\
\text { request, there is still } \\
\text { no refund or } \\
\text { payment. } \\
\text { [Consequence] No } \\
\text { negative } \\
\text { consequences. }\end{array}$ \\
\hline $\begin{array}{l}\text { Product Delivery } \\
\text { Problems }\end{array}$ & $\begin{array}{l}\text { [Failure] I buy things from } \\
\text { them several times a year } \\
\text { and have done so for years. } \\
\text { One of the items was meant } \\
\text { to be a gift and according to } \\
\text { the shipping estimate would } \\
\text { have arrived in plenty of time. } \\
\text { The week the item was } \\
\text { scheduled to be delivered I } \\
\text { received every other item I } \\
\text { have ordered except the gift. }\end{array}$ & $\begin{array}{l}\text { [Failure] The on-line site I } \\
\text { was dealing with was Indigo } \\
\text { Books. I had researched } \\
\text { their home-site to find this } \\
\text { bundle for the Eagles live } \\
\text { concert, and found that they } \\
\text { did indeed have } 6 \text { left. } \\
\text { Having made an order for } \\
\text { them, to date I have still } \\
\text { never been contacted in } \\
\text { regard to this purchase. }\end{array}$ & $\begin{array}{l}\text { [Failure] Buy product online } \\
\text { but it was not delivered to my } \\
\text { address. I wrote to the } \\
\text { company to advise that I do } \\
\text { not receive the parcel. So } \\
\text { they ship me another but the } \\
\text { product I wanted was not in } \\
\text { the parcel and the parcel was } \\
\text { left in front of my door. } \\
\text { [Consequence] Waste of }\end{array}$ & $\begin{array}{l}\text { [Failure] I made a } \\
\text { purchase for a } \\
\text { product online but } \\
\text { the package was not } \\
\text { delivered properly. } \\
\\
\text { [Consequence] No } \\
\text { negative } \\
\text { consequences. }\end{array}$ \\
\hline
\end{tabular}




\begin{tabular}{|c|c|c|c|c|}
\hline $\begin{array}{l}\text { Negative } \\
\text { E-Service } \\
\text { Failure Dimension }\end{array}$ & $\begin{array}{l}\text { Disconfirmed Outcome } \\
\text { Expectancy }\end{array}$ & $\begin{array}{c}\text { Disconfirmed Process } \\
\text { Expectancy }\end{array}$ & $\begin{array}{l}\text { Disconfirmed Cost } \\
\text { Expectancy }\end{array}$ & $\begin{array}{l}\text { No Disconfirmed } \\
\text { Expectancy }\end{array}$ \\
\hline & $\begin{array}{l}\text { What failed was Amazon } \\
\text { NOT informing that an item is } \\
\text { being shipped or not avail- } \\
\text { able on the date promised. } \\
\text { [Consequence] I had to pay } \\
\text { full retail for the gift at a local } \\
\text { store. }\end{array}$ & $\begin{array}{l}\text { [Consequence] To date I } \\
\text { have still never been con- } \\
\text { tacted in regard to this } \\
\text { purchase. I have been } \\
\text { emailing them for about } 5 \\
\text { months now with no real } \\
\text { follow up as how I can } \\
\text { purchase it on-line or direct } \\
\text { payment via Pay-Pal. It is as } \\
\text { if Indigo Book Store does not } \\
\text { care to make money? }\end{array}$ & time and energy. & \\
\hline $\begin{array}{l}\text { Unresponsive to } \\
\text { Customer } \\
\text { Enquiries }\end{array}$ & $\begin{array}{l}\text { [Failure] I was able to easily } \\
\text { find the product that I wanted } \\
\text { to purchase. I saw that there } \\
\text { was an area on the website } \\
\text { where I could ask a question } \\
\text { to which I submitted my } \\
\text { query. I submitted my query } \\
\text { and after two days, had not } \\
\text { received a response. I sub- } \\
\text { mitted another query, and } \\
\text { waited an additional two days } \\
\text { and still nothing. } \\
\text { [Consequence] The negative } \\
\text { consequences I experienced } \\
\text { because of my query not } \\
\text { being answered was that I } \\
\text { decided not to order the } \\
\text { product. }\end{array}$ & $\begin{array}{l}\text { [Failure] I have bided for a } \\
\text { chain online but did not } \\
\text { receive it from the seller. } \\
\text { E-Bay said they would look } \\
\text { into the matter and get back } \\
\text { to me with a resolution. It } \\
\text { has been about a month now } \\
\text { with NO resolution. } \\
\\
\text { [Consequence] The seller of } \\
\text { the item received my } \\
\text { payment via Pay-Pal ( } \$ \\
140.00) \text {, but has yet to send } \\
\text { me the chain as expected. }\end{array}$ & $\begin{array}{l}{[\text { Failure] I contacted }} \\
\text { customer service regarding a } \\
\text { refund for a defective product } \\
\text { I ordered online. They never } \\
\text { responded. } \\
\text { [Consequence] Delay in } \\
\text { receiving refund. }\end{array}$ & N/A \\
\hline
\end{tabular}

